\title{
AVALIAÇÃO DAS CONDIÇÕES PERIODONTAIS CLÍNICAS E HISTOLÓGICAS EM FUMANTES E NÃO-FUMANTES
}

\section{Lucinara Ignez Tavares Lussi}

Dissertação apresentada à Faculdade de Odontologia de Bauru, da Universidade de São Paulo, como parte dos requisitos para obtenção do título de Mestre em Odontologia - Área de Periodontia.

(Edição Revisada)

\section{BAURU}




\section{AVALIAÇÃO DAS CONDIÇÕES PERIODONTAIS CLÍNICAS E HISTOLÓGICAS EM FUMANTES E NÃO-FUMANTES}

\section{Lucinara Ignez Tavares Lussi}

Dissertação apresentada à Faculdade de Odontologia de Bauru, da Universidade de São Paulo, como parte dos requisitos para obtenção do título de Mestre em Odontologia - Área de Periodontia.

(Edição Revisada)

Orientador: Prof. Dr. Sebastião Luiz Aguiar Greghi

\section{BAURU}

2003 


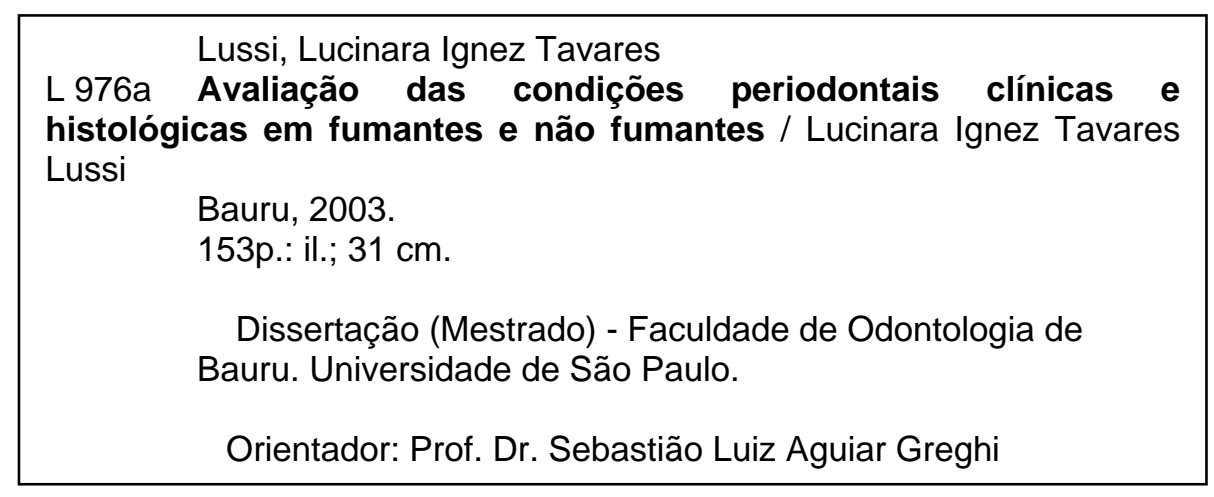

Comitê de Ética da FOB

No do Protocolo:019/2002/FOB

Data:30/08/2002

Autorizo, exclusivamente para fins acadêmicos e científicos, a reprodução total ou parcial desta dissertação/tese, por processos fotocopiadores e outros meios eletrônicos.

Assinatura: 


\section{Lucinara Ignez Tavares Lussi}

29 de setembro de 1969

São Miguel do Iguaçu-PR.

1987-1991

1995-1997

2000-2001

$2001-2003$

2003

Associações
Nascimento

Graduação em Odontologia

Faculdade de Odontologia de Pelotas/ UFPEL

Pelotas-RS

Curso de Especialização em Periodontia

Escola de Aperfeiçoamento Profissional -AONP

Associação Odontológica do Norte do Paraná

Londrina-PR

Professora Auxiliar do Curso de Odontologia, Disciplina de Estomatologia- UNIPAR -Universidade Paranaense Cascavel-PR

Professora do Curso de Aperfeiçoamento em Periodontia

ABO- Associação Brasileira de Odontologia - Secção Cascavel-PR

Professora Auxiliar da Disciplina de Periodontia UNIOESTE- Universidade do Oeste do Paraná Cascavel-PR

ABO-PR Associação Brasileira de Odontologia- Secção Paraná

CRO-PR Conselho Regional de Odontologia do Paraná 


\section{DEDI CATÓRI A}

À amada Edhuarda, por me proporcionar a vivência

e a alegria da maternidade. Ao esposo J osé Carlos, companheiro e incentivador sempre presente.

Ao meu irmão Evandro, Ani e Carollina, com carinho. Aos meus pais, Ignez e Armando que com a história de suas vidas escreveram a minha. A todos que de alguma forma contribuem na causa anti-tabagismo. 
"Entre

o passado e o presente, momentos difíceis, momentos sublimes e coragem para mudar a ilusão da perfeição" 
A Deus, por todas as

Graças recebidas.

À Faculdade de Odontologia de Bauru, Universidade Estadual de Londrina, que viabilizaram a

Realização do Mestrado Interinstitucional em Odontologia (MINTER).

Ao meu orientador,

Dr. Sebastião Luiz Aguiar Greghi, pela dedicação e condução deste trabalho. Ao Dr.

Euloir Passanezi, pelos ensinamentos. À Edilaine Torrecilha, I vânia Arruda e Marcos Godoy,

" elos " de comunicação na Disciplina de Periodontia. Aos

Coordenadores do MINTER, Dr. Newton Expedito de Moraes e Dra Maria Fidela de Lima Navarro, que não mediram esforços para que este momento pudesse se concretizar. Ao secretário do MINTER, Ricardo Campos, pela dedicação e apoio. Ao

Inspirador pela escolha desta especialidade, Dr.Geraldo Augusto Chiapinotto. À

Maria Luiza Lagos, Neli Caçador, Edna Mizuno, Geraldo Griza, Paulo Franzon Filho, Antonio Carrilho Neto, Flávio Justo, Feis Feres Junior e João Prata Carnio, pelo convívio e amizade, tão importantes nesta caminhada;

E aos "companheiros do asfalto" : Laélia Putrik, Maria de Fátima Thomazinho, Virginia Bosquiroli e Mauro A. Busato, que com suas "irreverências" minimizaram a distância do itinerário".

Às colegas da Endo: Dirce Nakamura e AVine França, pela cumplicidade e carinho;

No departamento de Ciências Biológicas, Dr. Rumio Taga, Dr.Gerson Francisco de Assis,

Tânia Cestarie Daniele Ceolin, pelo apoio incondicional na fase histológica .

Ao Dr. José Roberto Pereira Lauris, pela análise estatística.

Ao Maykon pela digitação e Edna pela formatação.

Aos pacientes pela fundamental contribuição.

Ouso repetir as palavras de minha mãe: “Ninguém vence sozinho, aqui está um pouco de todos nós". Por isso,

Sou grata a todos!. 


\section{SUMÁRIO}

LISTA DE FIGURAS ................................................................................ vii

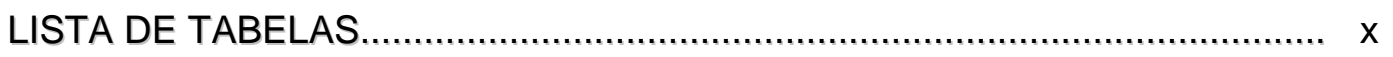

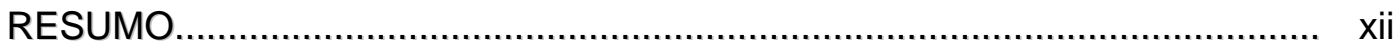

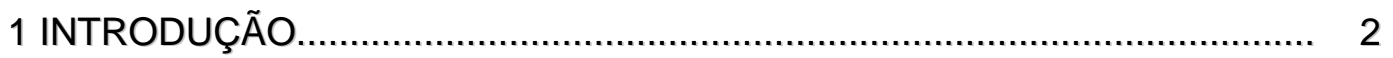

2 REVISTA DA LITERATURA ............................................................ 7

2.1 Reação vascular gengival sem e com influência do tabaco................... 7

2.2 Influência do tabaco nas reações celulares inflamatórias e imunes do periodonto............................................................ 20

2.3 Influência do tabaco na microbiota periodontal.................................. 25

2.4 Influência do tabaco na atividade de fibroblastos............................... 31

2.5 Influência do tabaco na condição periodontal................................... 36

2.6 Influência do tabaco na terapia periodontal........................................ 53

2.7 Tabagismo como fator de risco periodontal....................................... 63

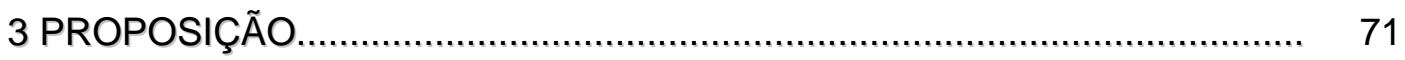

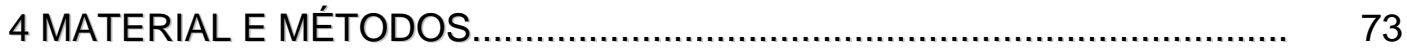

4.1 Seleção de amostra................................................................... 73

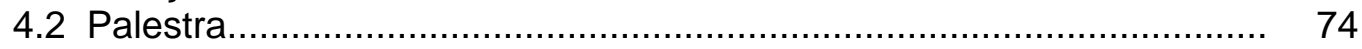

4.3. Registro das condições periodontias............................................... 74

4.4 Procedimentos de biópsia........................................................... $\quad 78$

4.5 Análise estatística................................................................... 81

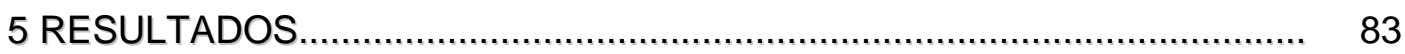

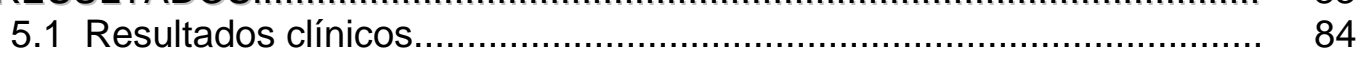

5.2 Resultados morfológicos.......................................................... 96

5.3 Resultados comparativos do teste " $\mathrm{t}$ " de student e do coeficiente de correlação de Pearson das variáveis clínicas e histomorfométricas........ 107

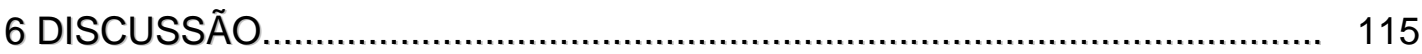

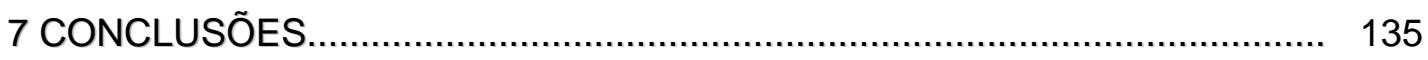

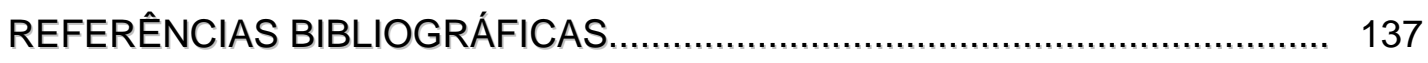

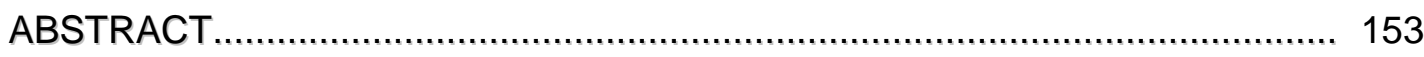




\section{LISTA DE FIGURAS}

FIGURA 1 Gráfico da profundidade de sondagem (Ps) por área (anterior e posterior), por face (vestibular, lingual/palatina, proximais) e por arcada (superior e inferior) entre os grupos de fumantes $\left(n^{\circ} 29\right)$ e não-fumantes( $\left.\mathrm{n}^{\circ} 26\right)$

FIGURA 2 Gráfico da recessão gengival(RG) por área (anterior e posterior), por face (vestibular, lingual/palatina, proximais) e por arcada (superior e inferior) entre os grupos de fumantes ( $n^{\circ} 29$ ) e não-fumantes ( $\left.n^{\circ} 26\right)$

FIGURA 3 Gráfico do nível de inserção clínica (NI) por área (anterior e posterior), por face (vestibular, lingual/palatina, proximais) e por arcada (superior e inferior) entre os grupos de fumantes $\left(n^{\circ} 29\right)$ e não-fumantes( $\left.n^{\circ} 26\right)$.

FIGURA 4 Gráfico do índice gengival por área (IG) (anterior e posterior), por face (vestibular, lingual/palatina, proximais) e por arcada (superior e inferior) entre os grupos de fumantes( $\left.n^{\circ} 29\right)$ e nãofumantes $\left(n^{\circ} 26\right)$

FIGURA 5 Gráfico do índice de sangramento à sondagem (ISG) por área (anterior e posterior), por face (vestibular, lingual/palatina, proximais) e por arcada (superior e inferior) entre os grupos de fumantes( $\left.n^{\circ} 29\right)$ e não-fumantes $\left(n^{\circ} 26\right)$

FIGURA 6 Gráfico do índice de placa (IP) por área (anterior e posterior), por face (mesial, centro da vestibular,distal, lingual, palatina) e por arcada (superior e inferior) entre os grupos de fumantes $\left(n^{\circ}\right.$ 29) e não-fumantes( $\left.n^{\circ} 26\right)$

FIGURA 7 Visão panorâmica da gengiva marginal de paciente fumante. Observar na vertente externa (Ve) epitélio gengival (EG) normal e na vertente dentária $(V d)$ o epitélio sulcular $(E S)$ e juncional (EJ) com moderada hiperplasia. Intenso infiltrado inflamatório desde a faixa limitante entre o sulco e durante toda a extensão da bolsa. HE, 38X.

FIGURA 8 Detalhe da figura anterior (paciente fumante) mostrando hiperplasia do epitélio sulcular (ES) sem projeções epiteliais. HE, 96X.

FIGURA 9 Detalhe da figura anterior (paciente fumante) na região da lâmina própria do epitélio sulcular exibindo fibras colágenas densas (asterisco), fibroblastos (setas largas) e raras células inflamatórias (setas), na maioria linfócitos, localizados na região próxima de vasos. HE, 384X.

FIGURA 10 Região mais cervical do epitélio juncional (paciente fumante) mostra hiperplasia do extrato suprabasal (asterisco). A lâmina própria associada ao epitélio apresenta intenso infiltrado inflamatório. HE, 384X. 
FIGURA 11 Visão panorâmica da gengiva marginal de paciente fumante. 100 Observar epitélio sulcular (ES) hiperplásico com projeções epitelias em forma de espículas (setas) e fragmentos de epitélio juncional $(E J)$ associados à intensa área inflamatória (asterisco) $\mathrm{HE}, 38 \mathrm{X}$

FIGURA 12 Detalhe da figura anterior (paciente fumante) mostrando 100 desorganização do epitélio da vertente dentária com inúmeras projeções irregulares do epitélio em forma de espículas (setas) associadas a áreas de infiltrado inflamatório (asterisco). HE, 96X.

FIGURA 13 Detalhe da figura anterior (paciente fumante), mostrando intenso 101 infiltrado inflamatório linfoplasmocitário (setas) e degradação das fibras colágenas (asterisco), HE, 384X.

FIGURA 14 Detalhe do infiltrado inflamatório(paciente fumante), exibindo 101 fibras colágenas dissociadas (asteriscos), hiperemia vascular e células inflamatórias (seta) perivascular. HE, 384X.

FIGURA 15 Visão panorâmica da gengiva marginal de 2 pacientes não- 103 fumantes. Observar na vertente externa o epitélio gengival (EG) com ausência das características papilares, o epitélio sulcular (ES) hiperplásico e juncional (EJ) associado a áreas de infiltrado inflamatório (setas) que ao longo da lâmina própria apresentouse em arranjo alguns difusos com algumas formações granulomatosas (asterisco). HE, 38X.

FIGURA 16 Detalhe da figura anterior, mostrando hiperplasia do epitélio do 103 sulco, áreas de infiltrado inflamatório (setas) dispersos na lâmina própria e presença de formações granulomatosas (asterisco). Notar a presença de inúmeros vasos hiperêmicos (setas largas). HE, 96X

FIGURA 17 Detalhe da formação granulomatosa no interior da lâmina 104 própria(paciente não fumante) com presença de linfócitos e macrófagos. HE, 384X

FIGURA 18 Detalhe( paciente não fumante) do infiltrado inflamatório (setas) 104 disperso por todo o tecido conjuntivo da lâmina própria do epitélio sulcular (ES). HE, 96X.

FIGURA 19 Lâmina própria de paciente não fumante, apresentando áreas 105 densamente vascularizadas (V) com células inflamatórias na região perivascular. $\mathrm{HE}, 384 \mathrm{X}$

FIGURA 20 Gengiva de paciente não fumante. Observar neste caso intenso 105 infiltrado inflamatório (setas) no tecido conjuntivo próximo ao epitélio do sulco (ES) e também, dispersos por toda a lâmina própria desde a vertente dentária até a vertente externa. HE, $38 \mathrm{X}$.

FIGURA 21 Detalhe do processo inflamatório próximo ao epitélio com 106 degradação das fibras colágenas (asterisco) e invasão de células inflamatórias (setas) para o interior do epitélio. HE, 384X. 
FIGURA 22 Camada reticular da lâmina própria, apresentando infiltrado 106 linfoplasmocitário com degradação das fibras colágenas (asterisco). HE, 384X.

FIGURA 23 Gráfico da análise comparativa das variáveis 108 clínicas(PS,IG,ISG,IP)dos 10 pacientes operados

FIGURA 24 Gráfico da análise comparativa da densidade de volume de 109 tecido normal (TN) e inflamado (TI) da lâmina própria da gengiva marginal dos 10 pacientes operados

FIGURA 25 Gráfico do número total de células inflamatórias e fibroblastos da 109 lâmina própria da gengiva marginal dos10 pacientes operados 


\section{니STA DE TABELAS}

TABELA 1 Análise comparativa (Teste " $\mathrm{t}$ " Student) da profundidade de sondagem (PS) por área (anterior e posterior), por face (vestibular, lingual/palatina, proximais) e por arcada (superior e inferior) entre os grupos de fumantes(n.29) e nãofumantes(n.26)

TABELA 2 Análise comparativa (Teste "t" Student) da recessão gengival 86 (RG) por área (anterior e posterior), por face (vestibular, lingual/palatina, proximais) e por arcada (superior e inferior) entre os grupos de fumantes (n.29) e não-fumantes (n.26)

TABELA 3 Análise comparativa (Teste "t" Student) do nível de inserção 88 clínica (NI) por área (anterior e posterior), por face (vestibular, lingual/palatina, proximais) e por arcada (superior e inferior) entre os grupos de fumantes $\left(n^{\circ} 29\right)$ e não-fumantes $\left(n^{\circ} 26\right)$

TABELA 4 Análise comparativa (Teste " $\mathrm{t}$ " Student) do índice gengival(IG) 90 por área (anterior e posterior), por face (vestibular, lingual/palatina, proximais) e por arcada (superior e inferior) entre os grupos de fumantes $\left(n^{\circ} 29\right)$ e não-fumantes $\left(n^{\circ} 26\right)$

TABELA 5 Análise comparativa (Teste "t" Student) do índice de sangramento à sondagem (ISG) por área (anterior e posterior), por face (vestibular, lingual/palatina, proximais) e por arcada (superior e inferior) entre os grupos de fumantes(n' $\left.n^{\circ} 2\right)$ e nãofumantes $\left(n^{\circ} 26\right)$.

TABELA 6 Análise comparativa (Teste "t" Student) do índice de placa (IP) por área (anterior e posterior), por face (mesial, centro da vestibular,distal, lingual/palatina) e por arcada (superior e inferior) entre os grupos de fumantes $\left(n^{\circ} 29\right)$ e não-fumantes $\left(n^{\circ}\right.$ 26)

TABELA 7 Análise comparativa (Teste "t" Student) das variáveis clínicas 108 (PS,IG,ISG,IP) e histomorfométricas(TN,TI,CEL.INF.,FIBROB.) dos 10 pacientes operados

TABELA 8 Coeficiente de Correlação de Pearson das variáveis clínicas 110 (PS,IG,ISG,IP) e histomorfométricas (TN,TI,CEL.INFL.,FIBROB.) dos 10 pacientes operados,em área de bolsa periodontal

TABELA 9 Coeficiente de Correlação de Pearson das variáveis clínicas 111 (PS,IG,ISG,IP) e histomorfométricas (TN,TI,CEL.INFL.,FIBROB.) de 5 pacientes fumantes, em área de bolsa periodontal 
TABELA 10 Coeficiente de Correlação de Pearson das variáveis clínicas 112 (PS,IG,ISG,IP) e histomorfométricas (TN,TI,CEL.INFL.,FIBROB.)de 5 pacientes não-fumantes,em área de bolsa periodontal

TABELA 11 Análise comparativa do número de dentes ausentes por área 112 (anterior e posterior) e arcada(superior e inferior) dos grupos de indivíduos fumantes e não-fumantes

TABELA 12 Coeficiente de correlação de Pearson de dentes ausentes (DA) 113 por área (anterior e posterior) e arcada (superior e inferior), número de cigarros/dia e tempo do vício/ano 


\section{RESUMO}

Condições periodontais clínicas e histológicas foram avaliadas em fumantes e não-fumantes. Participaram do estudo 55 indivíduos, dos quais 29 fumantes e 26 não-fumantes, entre 30 e 50 anos, com média de 40 anos de idade. Os parâmetros clínicos utilizados foram: profundidade de sondagem(PS), índice de placa(IP), índice gengival(IG), índice de sangramento gengival(ISG), nível de inserção clínica (NI) e recessão gengival(R). A análise histológica envolveu histomorfologia e histomorfometria do tecido conjuntivo gengival em área de bolsa periodontal de 10 indivíduos, 5 fumantes e 5 não-fumantes, selecionados aleatoriamente entre os grupos. Também foi considerado o tempo do hábito do fumo, a quantidade de cigarros fumados por dia e a quantidade de dentes ausentes em fumantes. Os resultados obtidos revelaram uma tendência de maiores médias de profundidade de sondagem, nível de inserção clínica e acúmulo de placa em fumantes, maiores médias de índice gengival para nãofumantes, menores médias de índice de sangramento gengival para fumantes e médias similares de recessão gengival entre os grupos. Os efeitos clínicos e histológicos foram menos expressivos em fumantes. Este mascaramento da doença periodontal provocado por reações vasculares, celulares e imunes, e o tempo do vício, podem resultar em prognósticos menos favoráveis da terapia periodontal em fumantes.

Palavras chaves: fumantes, condições clínicas, condições histológicas 
1 Introdução

(2) 


\section{Introdução}

É, hoje, francamente aceito que o tabagismo constitui sério problema de saúde pública. Além dos conhecidos efeitos nocivos causados ao organismo humano, tais como câncer, doenças coronarianas, cerebrovasculares, pulmonares obstrutivas crônicas e baixo peso em recém nascidos ${ }^{79,113}$, a cavidade bucal é diretamente afetada pelo hábito de fumar ${ }^{101}$. Segundo a Organização Mundial da Saúde ${ }^{83}$, dentre as 4720 substâncias isoladas no fumo, a nicotina é considerada uma droga responsável pela dependência, por meio de processos biopsicossociais parecidos com os da cocaína, álcool e heroína. Além disso, causa vasoconstrição na pele ${ }^{112}$, diminuição do fluxo sanguíneo ${ }^{103}$, prejuízo na cicatrização da ferida ${ }^{81}$ e é facilmente absorvida através da mucosa oral de fumantes ${ }^{44}$.

De acordo com MCGUIRE et al. ${ }^{75}$, a nicotina e seus subprodutos (cotinina) estariam presentes em concentrações seis vezes maiores no plasma, urina e fluido gengival, quando comparados à saliva. $\mathrm{O}$ hábito de fumar também afetaria o periodonto, causando destruição óssea e reforçando a hipótese de sua ação sistêmica ${ }^{6,18}$. Desta maneira, a nicotina tem sido relatada como responsável por uma série de alterações celulares que podem contribuir para o desenvolvimento da doença periodontal ${ }^{36,53,61}$.

Neste sentido, vários estudos demonstraram que o tabaco é, por si só, fator de risco na etiologia da doença periodontal, exercendo efeito 
local e sistêmico ${ }^{18,49,109}$. Também existem evidências de que o tabaco é um importante fator de risco para formas destrutivas de doença periodontal ${ }^{19,110}$.

Uma associação positiva entre cigarro, prevalência e severidade de periodontites e ocorrência de gengivite ulcerativa necrozante foi primeiramente relatada por mais de 4 décadas atrás ${ }^{6,90}$. Em estudos recentes, vem ocorrendo a confirmação de maior prevalência do tabaco para periodontites ${ }^{40,50,102}$, perda de inserção ${ }^{99}$, recessões ${ }^{30,31}$ e para respostas menos favoráveis ao tratamento periodontal ${ }^{1,9,26,30,33,47,62,72,82,99,111 .}$

Os fumantes têm sido considerados com maior prevalência de doença periodontal destrutiva severa em relação a nãofumantes ${ }^{16,18,19,24,37,38,43,58}$. Esta maior severidade da doença periodontal parece ser independente dos padrões de higiene oral, idade ou sexo.

A influência da higiene oral torna difícil discernir o efeito provocado apenas pelo fumo daquele provocado pela infecção bacteriana ${ }^{60}$. Conhecimentos recentes pertinentes à formação da placa não suportam a hipótese de que fumar interfira com a ocorrência natural de acúmulo de placa nas superfícies dentárias. Assim, permanece a possibilidade de que fumantes têm menos cuidado em relação a sua higiene oral e podem estar menos motivados a manter uma higiene oral padronizada ${ }^{12,20}$.

Em relação ao suprimento sangüíneo local no periodonto, a nicotina poderia estar envolvida com um efeito vasoconstritor significativo predispondo a um dano periodontal ${ }^{29,65}$. Estudos relacionando gengivite induzida por placa mostraram redução dos sinais clínicos em fumantes ${ }^{20,21}$ com menor propensão ao sangramento gengival ${ }^{91}$, devido a mudanças 
vasculares exercidas pelo fumo ${ }^{14}$. Desta maneira, a terapia não cirúrgica tem mostrado profundidade de sondagem de bolsa periodontal e perda de inserção clínica com maiores médias em fumantes quando, comparados a não-fumantes ${ }^{32}$. Os resultados à terapia periodontal cirúrgica ${ }^{10,78,111}$ e o reparo pós-terapia periodontal teriam resultados menos favoráveis em fumantes, quando comparados a não-fumantes ${ }^{46,92,93,97}$.

Estudos clínicos e epidemiológicos também relataram que a grande maioria das pessoas que apresentam condição refratária são fumantes ${ }^{71} \mathrm{e}$, ainda que existe reação dose-dependente, em que quanto maior a quantidade de cigarros fumados por dia e o tempo de duração do hábito, maior a perda óssea periodontal ${ }^{18,49,50,63}$.

Dentro deste contexto, o aumento da incidência de doença oral associada ao uso de tabaco é quase certamente devido à combinação de fatores, incluindo absorção local e sistêmica de suas substâncias, efeitos imunológicos ${ }^{39,56}$, efeitos químicos diretos, irritação térmica e efeitos vasoconstritivos da nicotina ${ }^{61}$.

É desejável mais estudo da relação tabaco-doença periodontal, uma vez que o efeito vasoconstritor da nicotina compromete a circulação periférica gengival com menor oxigenação e nutrição tecidual e menor renovação celular, ocorrendo diminuição da resposta inflamatória pelo comprometimento dos macrófagos e células leucocitárias, assim suprimindo o seu crescimento e as funções de fagocitose e quimiotaxia ${ }^{71}$ e havendo diminuição da produção de anticorpos específicos para bactérias envolvidas na doença periodontal ${ }^{84,87}$. 
Nesse mister, este trabalho teve como objetivo comparar aspectos clínicos e histológicos entre grupos de fumantes e não-fumantes e correlacioná-los dentro dos grupos. 
2 Revista da Literatura 


\section{Revista da Literatura}

Os trabalhos incluídos neste capítulo estão agrupados segundo seus objetivos principais, facilitando assim a concentração de opiniões em cada aspecto abordado como:

2.1 Reação vascular gengival sem e com a influência do tabaco

2.2 Influência do tabaco na reação celular inflamatória e imune do periodonto

2.3 Influência do tabaco na microbiota periodontal

2.4 Influência do tabaco na atividade de fibroblastos

2.5 Influência do tabaco na condição periodontal

2.6 Influência do tabaco na terapia periodontal

2.7 Tabagismo como fator de risco periodontal

\subsection{Reação vascular gengival sem e com influência do tabaco}

Mudanças histopatológicas sinalizando a inflamação gengival têm sido freqüentemente demonstradas antes de qualquer incidência clínica de inflamação. Até o estudo de EGELBERG ${ }^{34}, 1966$, HANSON; LINDHE; BRANEMARK, 1968, avaliações histológicas pós-experimentais ou clínicas pré-experimentais dos graus de inflamação na gengiva examinada eram superficiais ou inadequadas. Esta falta de controle em selecionar tecidos 
experimentais parece ter resultado em informações com inúmeros padrões vasculares diferentes, os quais eram considerados ser características da gengiva livre. Estes autores foram cuidadosos em conseguir gengiva clinicamente não inflamada em cães, anteriormente às suas observações experimentais. EGELBERG ${ }^{34}$ usou técnica de perfusão vascular, enquanto HANSON; LINDHE; BRANEMARK ${ }^{54}$ desenvolveram uma técnica de microscopia vital para investigar vasos sangüíneos gengivais. Suas descrições da topografia vascular foram comparáveis. Os autores ${ }^{54}$ descreveram uma rede de vasos sangüíneos que pareceram assumir configuração ondulada imediatamente adjacente ao epitélio marginal. Todos os vasos apresentavam-se arranjados em um plano paralelo ao epitélio juncional e a 90 graus em relação à gengiva marginal. Quando a gengiva tornou-se cronicamente inflamada, a rede de vasos foi substituída por ondulações torcidas, aumentando a altura total da gengiva livre. STALLARD ${ }^{108}$, 1968, relata que o estímulo afetando esta mudança na configuração vascular foi atribuído à proliferação do epitélio em várias camadas durante a inflamação.

O estudo de HOCK; NUKI ${ }^{55}$, 1971, teve como objetivo examinar a gengiva transiluminada "in vivo" e investigar a associação entre inflamação e morfologia de vasos adjacentes ao epitélio juncional. O tecido examinado se estendeu do nível de adesão epitelial para a margem gengival. Os autores estudaram o fluxo sangüíneo e reação vascular da gengiva livre intacta de fuinhas, graxains, gatos, cães e macacos Rhesus. 0 
estado de saúde gengival foi avaliado clinicamente, histologicamente e com microscópio vital e as três avaliações comparadas. Os resultados indicaram que a gengiva livre que nunca tivesse sido envolvida em inflamação exibiu uma morfologia vascular, descrita como uma rede. Com a manifestação de mudanças inflamatórias histopatológicas, a rede obtinha uma aparência de argola. O alongamento de vasos marginais marcaram a primeira mudança na configuração da rede. Uma vez alongados, os vasos não pareceram reverter a sua forma aparente, mesmo em gengiva com aparência não inflamada clínica e histopatologicamente. Outras mudanças observadas foram a dilatação dos vasos eferentes principais e a constrição de vasos aferentes principais. Os autores ainda relataram que as mudanças na topografia vascular gengival ocorreram antes de qualquer alteração de cristas epiteliais. Esta avaliação poderia contradizer a hipótese de que mudanças na interface tecidual epitélio-conjuntivo ditam as mudanças na topografia vascular descritas por EGELBERG ${ }^{34}$ e HANSSON'LINDHE; BRANEMARK $^{54}$.

SÖLDERHOLM, EGELBERG ${ }^{106}$, 1973, com a finalidade de estudar as alterações vasculares durante a gengivite, avaliaram os vasos sangüíneos situados na margem gengival. Quatro cães Beagle com idade de 12 a 36 meses foram incluídos no experimento, durante um período de 16 dias de desenvolvimento de gengivite. No total foram examinadas 48 áreas gengivais vestibulares, do segundo, terceiro e quarto pré-molares inferiores esquerdos. A gengiva clinicamente saudável foi obtida após controle da dieta 
e o polimento dentário realizado diariamente por um período de 12 semanas antes do início do experimento. A gengivite foi induzida pela eliminação do polimento dentário e mudança para uma dieta de consistência mais macia.

Fotografias foram tomadas do sistema vascular terminal, individual da margem gengival em intervalos regulares, durante 0 curso de desenvolvimento de gengivite: dia $0,2,4,7,9,14$ e 16 dias após iniciar o experimento. Alterações morfológicas nos vasos foram avaliadas através das fotografias. A reproducibilidade para as anotações durante o período, no entanto, foi prejudicada por um edema gradual do tecido gengival, o qual causou uma alteração na orientação dos vasos e uma mudança coronal da posição da margem gengival. Devido a essas condições, os vasos não puderam ser estudados pelas medições objetivas das fotografias. Algumas observações de interesse, no entanto, foram encontradas, como a largura aumentada e alteração no curso dos vasos. O aumento no diâmetro vascular foi observado durante a primeira semana do experimento, iniciando após o quarto dia. Alterações nos cursos dos vasos foram encontradas na segunda semana, após 11 dias, quando todo o sistema vascular mostrava alargamento.

BAAB, ÔBERG ${ }^{8}, 1987$, apresentaram os efeitos agudos de fumar cigarro no fluido sangüíneo gengival em 12 fumantes jovens entre 19 e 25 anos. Os voluntários fumavam entre 5 a 15 cigarros por dia por um tempo de 2 a 8 anos. O fluido sangüíneo gengival relativo (GBF) foi medido por uma sonda de fibra ótica Doppler com $0.85 \mathrm{~mm}$ de diâmetro, colocada a 
$1 \mathrm{~mm}$ no sulco vestibular do dente 26 . A sonda mediu continuamente o fluxo de células sangüíneas (velocidade $\mathrm{x}$ número de células) no sulco gengival. Devido aos efeitos complexos e potentes da nicotina no sistema cardiovascular, e efeitos divergentes no fluído sangüíneo às diferentes partes do corpo, também foram continuamente monitorados o fluido sangüíneo de pele para o antebraço (SBF), a taxa cardíaca e a pressão sanguínea (BP). Durante o fumo, a pressão sanguínea $(\mathrm{BP})$ e taxa cardíaca aumentaram significantemente. O fluido sangüíneo de pele para o antebraço decresceu durante e imediatamente após o fumo, mas somente nos sujeitos com altos níveis de vasopressina do plasma. O GBF aumentou quase linearmente quando a sonda foi colocada no sulco gengival. Este fenômeno não ocorreu quando a sonda foi colocada externamente na papila gengival. O estudo indicou que fumar cigarro causa preferivelmente um aumento significante do que uma diminuição na circulação sanguínea gengival, concluindo que a teoria de que fumar prejudica o fluido de sangue gengival, pode não ser verdadeira em humanos.

A influência de fumar cigarro na reação vascular de gengivite induzida por placa durante 28 dias, foi estudada em humanos por BERGSTROM; PERSSON; PREBER ${ }^{20}$,em 1988. Um total de 16 estudantes com saúde periodontal, sendo 8 fumantes, entre 23-38 anos e 8 nãofumantes, entre 19-42, anos participaram do estudo. Os fumantes tinham o vício de fumar há pelo menos 4 anos, consumindo de 10 a 20 cigarros por dia. A gengivite ficou limitada aos incisivos e caninos inferiores. Os fumantes 
mantiveram o hábito de fumar durante o curso da investigação. Os autores utilizaram um método fotográfico com filme colorido de $24 \times 36 \mathrm{~mm}$, para a avaliação da reação vascular nos incisivos centrais inferiores. As mudanças estereográficas foram monitoradas durante os dias $0,14,28$ durante 0 experimento e 7 e 14 dias após o experimento. Foi encontrado que o número de vasos identificados aumentou com o tempo, tanto em fumantes como nos não-fumantes. Contudo, apesar de não ter havido diferença no acúmulo de placa, a reação vascular foi menos pronunciada em fumantes. Após 28 dias, a reação vascular em fumantes era somente $50 \%$ da observada em nãofumantes. Uma semana após o experimento (35 dias) e restabelecimento da higiene oral, o número de vasos gengivais igualou-se em ambos os grupos. Os resultados indicaram que o fumo provocou constrição vascular e que a gengivite associada à placa estava suprimida em fumantes.

O estudo de JOHNSON; FUNG;SQUIER ${ }^{61}, 1989$, examinou os efeitos da nicotina na característica morfológica do sistema capilar subepitelial na mucosa oral de ratos, recebendo nicotina sistêmica deliberada por mini bombas $(1,5 \mathrm{mg} / \mathrm{kg} / \mathrm{dia})$ via subcutânea por 24 horas(aguda) ou em 2 semanas(crônica). Foram utilizados 16 ratos Sprague Dawley, divididos em três grupos. No grupo 1, cinco ratos receberam nicotina por administração sistêmica aguda (por um dia) de 1,5 mg/kg/dia. Estudos mostraram que esta dose produz níveis de nicotina no plasma semelhantes aos encontrados em fumantes humanos de um maço de cigarro por dia. No grupo 2, cinco ratos receberam nicotina por 
administração sistêmica crônica (por 14 dias) da mesma forma que o grupo 1. O grupo controle, com 6 ratos, recebeu salina. Após o tratamento, os animais foram sacrificados e as biópsias retiradas da mucosa do palato, gengiva superior e mucosa bucal. Cortes criostatos foram incubados para demonstrar fosfatase alcalina, a qual é um marcador capilar. O comprimento total do fragmento capilar nos grupos tratados com nicotina foi significantemente menor do que nos grupos controle. Houve também um decréscimo na altura capilar em ambos os grupos de nicotina, quando comparados aos animais controle. Este estudo indicou que alterações morfológicas ocorrem na microvasculatura da mucosa oral ao se administrar nicotina sistêmica. Isso pode ter implicações para o uso do tabaco crônico na etiologia da doença da mucosa oral, incluindo doença periodontal.

HUNTER $^{57}, 1991$, estudou a resposta vascular em gengivite e periodontite humana. Cinqüenta e uma biópsias foram obtidas de pacientes, imediatamente antes da extração de dentes, por razões clínicas. As biópsias foram classificadas em 3 grupos: biópsias de sítios com profundidade de sondagem com mais de $4 \mathrm{~mm}$ (periodontite), profundidade de sondagem de $3 \mathrm{~mm}$ (gengivite crônica),profundidade de sondagem menor de $3 \mathrm{~mm}$ (gengiva minimamente inflamada).As lesões gengivais tiveram índice gengival 2 ou mais e infiltrado inflamatório extenso e denso. Foram estudadas 15 espécimes com gengiva minimamente inflamada, 16 com gengivite crônica e 20 com periodontite. As biópsias foram divididas em 5 campos (fundo da bolsa, lateralmente à bolsa, crista gengival, epitélio oral, tecido conjuntivo) e 
uma investigação quantitativa das mudanças vasculares foi feita. Em campos adjacentes à irritação da placa bacteriana, vasos estavam aumentados em número com o desenvolvimento do aumento da lesão periodontal. O diâmetro dos vasos através de toda extensão das biópsias gengivais esteve aumentado com o avanço da doença periodontal. O estudo revelou que ocorre uma considerável remodelação na vasculatura gengival, no número e diâmetro dos vasos em biópsias gengivais de pacientes com gengivite e periodontite, podendo contribuir para a destruição vista nesta doença.

A proposta do estudo de McLAUGHLIN et al $^{76}, 1993$, foi determinar o efeito imediato de fumar um cigarro na taxa de fluido do sulco gengival (GCF) sobre o tempo. O estudo envolveu 17 voluntários sadios, com idade entre 19-57 anos (média 34,5 anos), com uma média de consumo de 10,6 cigarros por dia. Todos os indivíduos eram periodontalmente sadios, com índice de placa $<1$ e profundidade de sondagem $<4$. O GCF foi coletado nos sítios mesio-vestibular do segundo pré-molar superior esquerdo e direito, usando tiras de filtro de papel no local por 3 minutos. Amostras foram retiradas na linha base e subseqüentemente em intervalos de 10 minutos por 70 minutos. Foram utilizados dois tipos de fumo: por inalação (simulado) e por inspiração (fumado). O fumo simulado produziu diferentes respostas em diferentes sujeitos, e diferentes respostas em diferentes locais no mesmo sujeito. Um achado interessante em cada intervalo de tempo, antes e após o fumo por inalação e por inspiração foi visto em 5 fumantes 
pesados (15-20 cigarros por dia) que produziram volumes médios de GCF mais altos $(20 \min =0,689 \mu \mathrm{l}, 30 \mathrm{~min}=0,768 \mu \mathrm{l}, 40 \mathrm{~min}=0,803 \mu \mathrm{l}, 50 \mathrm{~min}=$ $1,485 \mu \mathrm{l})$ comparados com aqueles $(n=12)$ que fumavam menos do que 15 cigarros por dia $(20 \min =0,410 \mu \mathrm{l}, 30 \min =0 ., 54 \mu \mathrm{l}, 40 \min =0,489 \mu \mathrm{l}, 50$ $\min =0,945 \mu \mathrm{l})$. Embora a variação para todos os casos tenha sido grande, é imaginável que a saída do GCF após o fumo deva variar de acordo com o consumo de tabaco. Após o fumo simulado (inspiração) no tempo de 30 minutos, o volume GCF aumentou em média $16,7 \%$, e para o tempo de 50 minutos a média foi de $89,7 \%$. O aumento associado ao fumo inalado foi maior do que para o fumo simulado (por inspiração). Os resultados indicaram que o fumo produz um considerável aumento na taxa de fluido GCF e que estas alterações devem refletir as alterações ocorridas no fluido sangüíneo, que são conhecidamente produzidas pela nicotina. Os autores concluem que são necessárias mais investigações para determinar as razões precisas para o aumento transitório no fluxo de GCF após o fumo.

MATHENY; JOHNSON; ROTH ${ }^{74}, 1993$, compararam a dinâmica vascular gengival em 60 homens sadios, entre 18-75 anos, dos quais 20 sujeitos jovens de 18-25 anos (Y); 20 médios entre 35-45 anos (M); 20 idosos, 65-75 anos (O). A videomicroscopia de microvasos individuais e fluídometria de laser Dopller foram empregadas para avaliar a circulação gengival marginal. Parâmetros cardiopulmonares e sistêmicos foram monitorados como controles. O número de vasos visíveis gengivais no microscópio foi mais alto e o número de microvasos exibindo o fluido ativo foi 
mais baixo em $\mathrm{M}$ e O comparado ao $\mathrm{Y}$. Não houve diferença entre os grupos de idade nos valores do fluido do laser Dopller (fluido de sangue tecidual) ou na velocidade de células sangüíneas vermelhas nos vasos individuais. Embora não tenha sido estatisticamente significante com a idade, houve uma tendência da velocidade do fluído sangüíneo decrescer em ambos laser Dopller e medições de videomicroscopia. Os autores relataram que a pressão sangüínea aumentou levemente com a idade. A saturação do oxigênio periférico foi mais baixa em $\mathrm{O}$ comparado ao $\mathrm{Y}$ e $\mathrm{M}$. Nenhuma diferença foi vista na taxa cardíaca, taxa respiratória ou concentração de dióxido de carbono. As alterações na pressão sangüínea e a saturação do oxigênio foram esperadas. As diferenças em número de vasos visíveis e número de vasos com fluído sangüíneo ativo podem refletir adaptação da microcirculação gengival com a idade para alterar a necessidade nutricional ou o desafio microbiológico e/ou mecânico. Os autores demonstraram que existe um aumento no número de microvasos visíveis por área de unidade na gengiva humana com a idade e que o número desses microvasos exibe fluido ativo decrescido com a idade. Através dos dados presentes, os autores foram incapazes de determinar se essa alteração reflete uma alteração de número atual de vasos ou meramente uma mudança no número de vasos patentes.

A influência do fumo nas características vasculares em indivíduos periodontalmente saudáveis foi estudada por PERSSON; BERGSTRÖM ${ }^{86}$,1998. Participaram do estudo 14 alunas de Odontologia, por 
um período de 11 semanas. A média de idade foi de 30,4 anos (25-38 anos). Sete das estudantes eram fumantes de 10 a 25 cigarros/dia. 0 padrão de higiene oral entre as participantes foi alto. Fotodocumentação foi executada em quatro ocasiões com auxílio de um método estereofotográfico. As características dos vasos gengivais foram avaliadas de acordo com um índice vascular semi-quantitativo, baseado na morfologia e número de vasos dentro de cada área da gengiva marginal. Os resultados indicaram que a densidade vascular não foi estatisticamente diferente entre fumantes e nãofumantes. Além disso, a densidade vascular permaneceu estável em ambos os grupos. Esses resultados sugeriram que a densidade vascular em gengiva marginal não é influenciada pelo fumo moderado desde que prevaleçam condições de saúde gengival.

HANIOKA et al. ${ }^{53}, 2000$, objetivaram comparar a saturação de oxigênio da hemoglobina $\left(G_{S}{ }^{2}\right)$ de fumantes e não-fumantes com periodontite leve a moderada, para avaliar o efeito crônico de fumar na função microcirculatória gengival. Cento e dez sítios da gengiva papilar de 62 fumantes e 100 sítios de 60 não-fumantes da área de incisivos, caninos e pré-molares superiores foram sondados. Os autores não encontraram diferenças significantes na $\mathrm{GSo}^{2}$ entre fumantes e não-fumantes. No modelo estatístico da ANOVA, a idade e profundidade de sondagem tiveram efeitos significantes na GSo ${ }^{2}$. Efeitos não significantes foram encontrados no status de fumar e no índice gengival modificado (MGI), indicando que o efeito do status de fumar na saturação de oxigênio da hemoglobina $\left(\mathrm{GSo}^{2}\right)$ deveria 
ser comparado em cada nível de escore do índice Gengival Modificado (MGI). GSo $^{2}$ em gengiva saudável foi significantemente mais baixo em fumantes que em não-fumantes, enquanto fumantes mostraram maior GSo $^{2}$ que não-fumantes em gengiva moderadamente inflamada. O $\mathrm{GSo}^{2} \mathrm{em}$ gengiva inflamada foi significativamente menor, comparado com a gengiva sadia em não-fumantes, enquanto fumantes não mostraram diferença significante entre gengiva sadia e inflamada. GSo $^{2}$ em fumantes foi consistentemente e significantemente mais baixo do que aquele de gengiva sadia em não-fumantes. Os autores concluíram que os fumantes exibiram possibilidade mais baixa de função de suficiência de oxigênio em gengiva sadia e habilidade reduzida de adaptar a função em gengiva inflamada do que não-fumantes, sugerindo que fumantes tiveram prejuízo funcional na microcirculação gengival.

BERGSTRÖM; BOSTRÖM ${ }^{15}$, 2001, estudaram a influência do cigarro na reação hemorrágica periodontal em 2 diferentes populações de pacientes. A população 1 incluiu um total de 243 pacientes, 168 homens e 75 mulheres, selecionados da lista de espera do Departamento de Periodontologia, Instituto Karolinska, Huddinge, Sweden. A idade variou entre 30-86 anos, com média de 55 anos. Os pacientes apresentavam periodontite moderada a avançada com sondagem de bolsa de $6 \mathrm{~mm}$ ou mais e radiografia de perda óssea. Foram selecionados apenas pacientes fumantes ou nunca fumantes. Os que relataram ter deixado o hábito de fumar foram excluídos da pesquisa. Entre os fumantes, a média de consumo 
era de 20 cigarros/dia por um período de 27 anos. A população 2 incluiu um total de 95 pacientes, 54 homens e 41 mulheres, entre 26-88 anos, com média de 57 anos de idade. Estes pacientes foram selecionados dos arquivos da School of Dentstry, Karolinska Institutet, Huddinge, Sweden, por examinação e/ou tratamento de desordens orais ou dentais durante 5 anos antes do estudo. Foram incluídos apenas pacientes com documentação sem dúvidas em relação ao hábito ou não de fumar. A média de cigarros fumados era de 10/dia por um período de 30 anos. Na população 1 , a reação hemorrágica dos pacientes foi encontrada clinicamente, através de leve sondagem dos sítios bucal, distal, lingual e mesial, com sonda de Hilming com diâmetro de $0.5 \mathrm{~mm}$ e expressada como freqüência relativa dos locais que sangravam (\%) após 30 segundos de sondagem com força de $0,25 \mathrm{~N}$ (índice de sangramento gengival-GBI). A profundidade de sondagem também foi medida nos mesmos locais do GBI. Sítios com profundidade de $4 \mathrm{~mm}$ ou mais foram definidos como doentes, e a freqüência relativa de sítios doentes (DS) foi expressa em \% do número total de sítios. A placa supragengival foi considerada presente ou ausente nas superfícies vestibulares, distais, linguais e mesiais de todos os dentes. O nível de placa $(P L)$ foi dado pela freqüência de superfícies positivas de placa com \% do número de superfícies examinadas.Na população 1, toda a avaliação clínica periodontal foi realizada por um único examinador, enquanto na população 2, os exames apesar de descritos com os mesmos critérios clínicos que para a população 1, foram coletados dos arquivos, realizados por um grande número de examinadores não calibrados com força de sondagem não conhecida. Os autores relataram que fumantes exibiram uma reação 
hemorrágica menor do que não-fumantes, porém este efeito foi mais claramente detectável nos pacientes periodontais que no grupo de pacientes dos arquivos do Hospital Dental. O efeito da dose-reação para severidade de doença periodontal foi tipicamente evidente na população 1, quando levado em conta a severidade da doença periodontal, contudo, o efeito do cigarro tornou-se claramente detectável também na população 2. Os autores concluíram que fumar cigarro está associado com reação hemorrágica suprimida no periodonto.

\subsection{Influência do tabaco nas reações celulares inflamatórias e imunes do periodonto}

EICHEL; SHAHRIK ${ }^{36}, 1969$, apud RIVERA ${ }^{100}, 1986$,relataram a perda da função leucocitária em humanos por causa do fumo. Eles descobriram que um único cigarro pode inibir completamente a ação dos PMN salivares "in situ", devido à toxicidade do tabaco.

KENNEY, SAXE, BOWLES ${ }^{67}, 1975$, testaram a hipótese de que variações no potencial de oxi-redução (Eh), na região gengival e cavidade oral, seriam indicativos de anaeróbios na área. O fumo causaria diminuição do Eh e aumentaria as bactérias anaeróbias na placa. Os valores Eh na região gengival diminuiriam significativamente depois de fumar 1 cigarro. Esta redução foi acompanhada por pequeno, mas significativo aumento no 
pH. Culturas aeróbias e anaeróbias, em fumantes e não-fumantes, falharam em revelar alguma diferença estatisticamente significante. Na proporção de culturas anaeróbias contudo, houve maior proporção para fumantes.

O estudo de KENNEY et. $\mathrm{al}^{66}, 1977$, incluiu fumantes e nãofumantes, com semelhantes idade e saúde gengival, para avaliar o efeito de fumar cigarro nos Leucócitos polimorfonucleares orais(PMN).As células foram colhidas pelo enxágüe de boca com solução salina. Os PMN foram testados para sua habilidade de fagocitar esferas de látex e para eliminar o azul de tripano. Testes foram realizados para fumantes e não-fumantes em três dias consecutivos, com procedimentos idênticos, exceto que todo participante fumou um cigarro no segundo dia, imediatamente antes de coletar as células. Os PMN de fumantes foram menos vitais para o teste de eliminação da solução e foram menos capazes de fagocitar partículas em cada dia experimental. Fumar um cigarro imediatamente antes da coleta das células resultou em diminuição da viabilidade e atividade de fagocitose de PMN. Similarmente, a quimiotaxia "in vivo" e a migração associada à inflamação gengival em PMN também foram diminuídas pelo fumo.

Com o propósito de delinear os efeitos da nicotina nas funções antimicrobianas de neutrófilos e monócitos "in vitro", PABST et al. ${ }^{84}, 1995$, analisaram a atividade bactericida contra os patógenos orais e a habilidade para produzir oxigênio reativo microbicida (radicais de oxigênio) destas células. A exposição de neutrófilos sangüíneos humanos a altas 
concentrações de nicotina $(0,01 \%$ a $0,3 \%)$ inibiu sua habilidade bactericida para Actinomyces naeslundii, Actinobacillus actinomycetemcomitans, e Fusobacterium nucleatum. A nicotina interferiu na liberação de oxigênio reativo pelos neutrófilos. O principal metabólito da nicotina, cotinina, demonstrou uma habilidade similar para inibir a produção de radicais de oxigênio pelos neutrófilos. A nicotina não teve efeito inibitório quando a avaliação da capacidade bactericida foi realizada em um ambiente anaeróbico, implicando que a nicotina afetou preferencialmente mecanismos na inibição de bactérias dependentes de oxigênio. A droga teve dois efeitos na liberação de oxigênio reativo: bloqueio da tomada do oxigênio e da síntese de superóxido e peróxido; e absorção direta de algum superóxido que foi produzido. Esses dois efeitos devem ser sinérgicos, permitindo que concentrações baixas de nicotina interferissem na morte bacteriana aeróbica. Os autores concluíram que a inibição da função antimicrobiana aeróbica de neutrófilos e monócitos pela nicotina pode alterar a ecologia microbiológica da cavidade oral, e isto deve ser um mecanismo pelo qual a nicotina compromete a saúde oral dos usuários dos produtos de tabaco. Nesses usuários, a inibição de funções de fagócitos pela nicotina poderia comprometer sua habilidade bactericida para os patógenos periodontais, ou a sinalização da presença de infecção para outras células do sistema.

A proposta do trabalho de BERNZWEIG et al. ${ }^{23}, 1998$, foi investigar em indivíduos não-fumantes com periodontite do adulto, o efeito da nicotina na secreção de mediadores, reabsorvendo osso, interleukina-1 $\beta$ 
$(\mathrm{IL}-1 \beta)$ e de prostaglandina $\mathrm{E}_{2} \quad\left(\mathrm{PGE}_{2}\right)$, por células mononucleares sangüíneas (monócitos e linfócitos) periféricas(PMBC) e gengivais (GMC). Foi retirado sangue periférico e do tecido gengival adjacente à crista alveolar. O estudo indicou que a nicotina pode estimular as PBMC para secretar $\mathrm{PGE}_{2}$, mas que a ativação de células mononucleares gengivais pode não ocorrer, possivelmente devido à estimulação prévia máxima na lesão de periodontite.

A influência de fumar na atividade de neutrófilos gengivais, em jovens adultos, periodontalmente sadios, foi estudada por PERSSON et al. ${ }^{87}$, 1999. A atividade de neutrófilos foi medida em termos de fluido sulcular gengival (GCF) para níveis de elastase, lactoferrina (LF), $\alpha$-1-antitripsina ( $\alpha$ 1AT), $\alpha-2-$ macroglobulina ( $\alpha-2-M G$ ) e proteína. Participaram do estudo 30 estudantes de Odontologia sem sinais clínicos de periodontite, sendo 15 fumantes (8 mulheres e 7 homens) idade de 20-32 anos e 15 não-fumantes (7 mulheres e 8 homens) idade de 22-31 anos. A condição gengival foi registrada em 6 locais e o volume GCF foi coletado dos mesmos locais. O volume GCF foi medido com Periotron 6000. A atividade de elastase foi medida com um substrato molecular baixo cromogênico e os níveis LF, níveis $\alpha-2-M G$ e $\alpha-1-A T$ foram determinados com ELISA. Os resultados demonstraram um volume GCF mais baixo e estatisticamente significante entre os fumantes, quando comparados aos não-fumantes. Nenhuma diferença significante foi encontrada na atividade elastase/ $\mu$ l entre os fumantes e não-fumantes, mas houve uma grande variação interindividual . 
Nem as concentrações de LF, $\alpha-1-A T, \alpha-2-M G$ e proteína por $\mu$ de GCF diferiram significantemente entre os 2 grupos. Os resultados sugeriram que a influência do fumo nos fatores examinados associados com atividade de neutrófilos é limitada sob condições de gengiva levemente inflamada ou sadia, produzindo somente pequena diminuição na quantidade de fluido sulcular gengival (GCF).

Em 2001, PERSSON et al. ${ }^{88}$ investigaram a influência de fumar tabaco nos níveis de elastase do fluido sulcular gengival (GCF), lactoferrina (LF), $\quad \alpha$-1-antitripsina $\quad(\alpha-1-A T), \quad$ e $\quad \alpha-2-m a c r o g l o b u l i n a ~(\alpha-2-M G)$ sob condições de periodontite. Participaram da pesquisa 15 fumantes (5 mulheres e 10 homens) com idade de 34 a 69 anos e 17 não-fumantes (5 mulheres e 12 homens) com idade de 31 a 81 anos. Foram realizados registro clínico do índice gengival $(\mathrm{Gl})$, índice de placa $(\mathrm{PI})$ e profundidade de sondagem. Amostragens de GCF foram feitas em 3 locais com lesões severas e em 3 locais com lesões moderadas em cada indivíduo. A atividade da elastase foi medida com um substrato molecular baixo cromogênico e o LF, $\alpha-1-A T$, e concentrações de $\alpha-2-M G$ com ELISA. Os resultados demonstraram que, em relação à lesão severa, fumantes tiveram significantemente concentrações mais baixas de $\alpha-2-M G$ e as quantidades totais de $\alpha-2-M G$ e $\alpha-1-A T$ do que não-fumantes. Com relação a lesões moderadas, fumantes tenderam a exibir uma concentração mais baixa de $\alpha$ 2-MG, mas a diferença não foi estatisticamente significante. Comparando lesões severas e moderadas, fumantes não exibiram aumento de LF e $\alpha$-2- 
MG com a severidade da doença em contraste aos não-fumantes, que demonstraram significantemente ou quase significantemente níveis aumentados de LF e $\alpha-2-M G$ em lesões severas, quando comparadas a lesões moderadas. Os resultados indicaram que os níveis de $\alpha-2-\mathrm{MG}$ e $\alpha-1$ AT foram suprimidos em fumantes com periodontite, sugerindo que o fumo interfere nestes inibidores de protease. Esse pode ser um mecanismo pelo qual o fumo afeta a resposta inflamatória.

\subsection{Influência do tabaco na microbiota periodontal}

BASTIAAN;WAITE ${ }^{12}$, 1978, estudaram 2 grupos de indivíduos entre 17 e 29 anos a fim de comparar o nível de formação de placa. Relataram que houve uma tendência de maior formação de placa em fumantes, porém não sendo estatisticamente significante. Os autores também descobriram percentagem maior de bactérias Gram-positivas que Gram-negativas em fumantes. No desenvolvimento da placa, as bactérias Gram-negativas foram mais suscetíveis ao fumo que as Gram-positivas. Nos estágios iniciais de formação de placa (terceiro dia) houve predominância de Gram-positivas para fumantes e não-fumantes, mas, por volta do sétimo e décimo dia, o percentual foi similar para ambos os grupos. O significado deste achado não ficou claro.

BARDELL ${ }^{11}, 1981$, apud RIVERA ${ }^{100}$ estudou “in vitro" seis espécies de bactérias orofaríngeas depois da exposição ao cigarro. Esta exposição resultou em marcada diminuição quanto ao número de bactérias 
viáveis. As espécimes de bactérias Gram-negativas(Branhamella catarrhalis, Neisseria perflaxia, Neisseria sicca)eram mais susceptíveis ao fumo do que as Gram-positivas (Streptococcus mitis, Streptococcus salivares, Streptococcus sanguis) e descobriu-se que cigarros sem filtro provocaram efeito mais deletério às bactérias.

PREBER; BERGSTROM; LINDER ${ }^{94}$, 1992, estudaram 142 indivíduos com periodontite de adulto para analisar o efeito do cigarro na microbiota subgengival. O estudo mostrou que contagens de Actinobacillus actinomycetemcomitans, Bacteróides gingivalis (Porphyromonas gingivalis) e Bacteróides intermedius (Prevotella intermedia) não foram significantes entre fumantes e não-fumantes. Os resultados foram baseados em amostra de placa simples de bolsas com profundidade $\geq 6 \mathrm{~mm}$.

Em 1993,STOLTENBERG et al. ${ }^{109}$ encontraram resultados semelhantes ao de PREBER; BERGSTROM; LINDER ${ }^{94}$, 1992, Os autores avaliaram amostras de placa subgengival do sextante posterior em 615 adultos para a presença de $A$. Actinocetamcomitans, $P$. gingivalis, $P$. intermedia, Eikenella corrodens e Fusobacterium nucleatum. Não foram encontradas diferenças significantes na prevalência de nenhuma das espécies testadas entre fumantes e não-fumantes A presença de cada espécie e o fumo foram associados com o aumento do risco da média de profundidade de bolsa $\geq 3.5 \mathrm{~mm}$, sendo o fumo o maior indicador de risco para o aumento da profundidade de sondagem. 
PREBER; LINDER; BERGSTRÖM ${ }^{97}, 1995$, monitoraram os efeitos microbiológicos e clínicos da terapia não cirúrgica em fumantes e não-fumantes. $O$ estudo incluiu 32 indivíduos entre 32 e 61 anos de idade, sendo 11 homens e 21 mulheres com periodontite moderada à severa, dos quais 17 fumantes ( $\geq 15$ cigarros/dia) e 15 não-fumantes. Todos os pacientes foram submetidos à terapia periodontal não cirúrgica realizada por higienista dental. Variáveis periodontais (índice de placa, índice gengival e profundidade de sondagem) foram registradas. Amostras bacterianas foram coletadas antes e 2 meses após o tratamento. $\mathrm{O}$ tratamento resultou em reduções significantes de placa e índice gengival, semelhantes em fumantes e não-fumantes. Embora a profundidade de sondagem tenha reduzido em ambos os grupos, a redução da profundidade de bolsa à sondagem foi significantemente menor em fumantes do que em nãofumantes. Microbiologicamente, a mesma eficácia terapêutica foi atingida em ambos os grupos, indicando uma erradicação quase total de Actinobacillus actinomycetemcomitans e Porphyromonas gingivalis. Os resultados sugeriram uma resposta clínica menos favorável da terapia não cirúrgica em fumantes do que em não-fumantes, independente do fato de que a terapia tenha sido equivalentemente efetiva com relação a reduzir os periopatógenos $A$. actinomycetemcomitans, $P$. gingivalis e $P$. intermédia.

Em 1996 ZAMBON et al. ${ }^{115}$ examinaram 798 indivíduos fumantes ou ex-fumantes e 638 não-fumantes, com idade entre 25 e 74 
anos. Houve constatação da presença de Bacteróides forsythus em número de 2 a 3 vezes maior nos indivíduos fumantes em relação aos não-fumantes ou ex-fumantes. Os autores observaram que, quando os indivíduos eram portadores de semelhantes níveis de doença periodontal, o número de bactérias com potencial patogênico era maior em fumantes, quando comparados aos não-fumantes. Os autores concluíram que o fumo do cigarro aumenta a probabilidade de infecção subgengival, devido ao achado de uma microbiota compatível com certas doenças periodontais nestes indivíduos. Isso, segundo os autores, explicaria parcialmente um maior risco de ocorrência de periodontite em fumantes.

O estudo de LIE et al. ${ }^{68}, 1998$, objetivou investigar a microbiota oral em fumantes e não-fumantes com gengivite estabelecida, monitorando sua composição e avaliar se esta composição da microbiota estaria associada com diferentes níveis de inflamação gengival durante a gengivite experimental. Participaram da pesquisa 25 estudantes universitários, entre 19 e 25 anos (média 22 anos). Os indivíduos deveriam apresentar 24 dentes ou mais, presença de gengivite (> $30 \%$ de sangramento a sondagem), ausência de bolsas $\geq 5 \mathrm{~mm}$, ausência de perda de inserção interproximal, boa saúde geral e não ter tomado antibiótico nos últimos 6 meses. Foram selecionados 11 indivíduos fumantes que consumiam em média 15,6 cigarros por dia e 14 não-fumantes. Após atingir a saúde gengival através de instruções de higiene oral e profilaxia profissional, eles foram submetidos à gengivite experimental por 14 dias, abstendo-se de higiene oral. Índice de 
placa e de sangramento foram avaliados na linha base, no dia 0 , no $5^{\circ}$ dia, e $14^{\circ}$ dia do experimento. As amostras microbiológicas de locais de mucosa e placa dental foram analisadas para a presença de espécies de Actinomyces, Actinobacillus actinomycetemcomitans, Bacteróides forsythus, Campylobacter rectus, Fusobacterium nucleatum, Peptostreptococcus micros, Porphyromonas gingivais, Prevotella intermedia e Streptococcus. No $14^{\circ}$ dia do período experimental, o nível de formação de placa não foi diferente entre os fumantes e não-fumantes, mas os escores de sangramento foram de $15 \%$ em fumantes e $30 \%$ nos não-fumantes. A alteração de gengiva saudável para gengivite induzida experimentalmente foi quantitativa na microbiota cultivável em ambos os grupos. Estas alterações foram mais predominantes na transição da saúde gengival para a gengivite experimental, sendo encontradas as espécies de Actinomyces , C. Rectus, F. nucleatum, e P. intermédia. Nenhuma relação com uma espécie bacteriana pôde ser estabelecida, a qual provavelmente explicaria as diferenças nos níveis de inflamação. Os autores concluíram que em adultos jovens, o nível de gengivite, desenvolvido em resposta ao acúmulo de placa, diferiu entre fumantes e não-fumantes, sendo maior em não-fumantes. Também as diferenças na resposta para gengivite experimental foram quantitativas e não qualitativas em relação à microbiota.

KAMMA, NAKOU, BAENI ${ }^{64}, 1999$, revisaram alguns dos fatores que têm se mostrado divergentes em relação ao fumo. Eles notaram que fumar reduziu a atividade funcional de macrófagos e leucócitos, assim como 
diminuiu a quimiotaxia e fagocitose de PMN. O potencial de oxi-redução na placa dental mostrou estar aumentado pelo fumo, possivelmente estimulando o crescimento de bactérias anaeróbicas ${ }^{66}$. O fumo mostrou diminuir a produção de anticorpos lgG2 em sujeitos com periodontite de início precoce. Desde que estes anticorpos favorecem a uma maior resposta sérica para os patógenos periodontais, esta diminuição poderia afetar a composição da placa subgengival. Estes efeitos indesejáveis do cigarro poderiam levar à potencialização de mudanças prejudiciais na microbiota de fumantes. Desta maneira, resultando em diferenças nos aspectos clínicos, imunológicos e locais entre fumantes e não-fumantes. Assim, a expectativa seria de que fumantes poderiam ter uma microbiota mais anaeróbica em relação aos não-fumantes.

A investigação de HAFFAJEE; SOCRANSKY ${ }^{51}, 2001$,teve como propósito entender as diferentes conclusões sobre a relação de fumar com a placa subgengival. Estas diferenças poderiam ser explicadas por diferentes populações, número de indivíduos, número de amostras avaliadas, espécies examinadas, método de enumeração expressão, e evolução bacteriana. $\mathrm{O}$ estudo examinou a prevalência, proporções e níveis de espécies subgengivais em indivíduos fumantes usuais, ex-fumantes e nunca fumantes. Um total de 272 adultos, entre 20-86 anos, com no mínimo 20 dentes, foram selecionados. Os dados clínicos foram obtidos de 6 sítios por dente de todos os dentes, excluindo os terceiros molares. As amostras de placa foram obtidas das superfícies mesiais de todos os dentes. Análises uni 
e multi variáveis foram usadas para procurar associações entre categorias de fumantes e contagens, proporções e prevalência de espécies subgengivais. Grandes diferenças foram observadas para a prevalência das espécies teste nos 3 grupos. Membros dos complexos laranja e vermelho incluindo $E$. nodatum, $F$. nucleatum ss vincentii, $P$. intermedia, $P$. micros, $P$. nigrescens, $B$. forsythus, $P$. gingivalis e $T$. denticola foram significativamente mais prevalentes em fumantes usuais do que nos outros 2 grupos. $\mathrm{O}$ achado mais importante do estudo foi que patógenos periodontais suspeitos ou conhecidos foram mais prevalentes, por exemplo, colonizaram mais sítios, em fumantes usuais do que em ex-fumantes ou não-fumantes. A diferença na prevalência entre fumantes e não-fumantes foi devida a maior colonização de sítios com profundidade de sondagem $>4 \mathrm{~mm}$. A diferença na prevalência das espécies ajuda a explicar a maior severidade de destruição em fumantes do que em não-fumantes, desde que mais sítios estão em risco por estarem colonizados por patógenos potenciais, em indivíduos fumantes. As diferenças nos padrões de colonização entre fumantes usuais e nunca fumantes foram maiores na maxila que na mandíbula.

\subsection{Influência do tabaco na atividade de fibroblastos}

RAULIN et al. ${ }^{98}, 1988$, examinaram o efeito da nicotina na inserção do fibroblasto "in vitro" em superfície radicular humana não doente. Fibroblastos humanos (HFF) foram tripsinizados, e encubados com cortes radiculares humanos, autoclavados em concentrações de nicotina de 
zero (controle), 25, 50, 100, 200 , ou $400 \mathrm{ng} / \mathrm{ml}$. Os cortes radiculares foram examinados para inserção do fibroblasto em 24, 48, e 72 horas pelo microscópio óptico e microscopia eletrônica de varredura (SEM). HFF tripsinizados adicionalmente foram incubados em superfícies de vidro com as mesmas concentrações da nicotina e examinados em uma semana pelo microscópio óptico. HFF inseriram e cresceram no vidro e superfícies radiculares em todas as concentrações de nicotina. Controles nas superfícies de vidro exibiram uma monocamada normal de fibroblastos em forma de fusiformes com um alinhamento paralelo e sobreposicionamento mínimo. HFF tratados com nicotina exibiram uma disposição prejudicial com sobreposição celular e vacuolização do citoplasma. Sob o SEM, os controles tinham superfícies regulares e apareceram firmemente inseridos à superfície radicular. HFF expostos à nicotina se projetaram longe da superfície radicular. Esses encontros sugeriram que a natureza da inserção do fibroblasto ao vidro e superfície radicular é alterada pela nicotina. Um distúrbio similar na inserção do fibroblasto pode ocorrer em humanos que usam produtos contendo nicotina, fazendo-os mais suscetíveis à destruição do periodonto e menos responsivos às novas inserções após a terapia periodontal.

Objetivando analisar " in vitro" a interferência da nicotina sobre a capacidade de adesão de fibroblastos, PEACOCK et al ${ }^{85}, 1993$, estudaram o comportamento de fibroblastos gengivais humanos mantidos em cultura. Os autores observaram se alguns efeitos vistos no crescimento de 
fibroblastos gengivais humanos persistiriam após a remoção da nicotina, e se a nicotina teria algum impacto sobre a inserção do fibroblasto. Foram utilizadas concentrações de nicotina de $0,025,0,05,0,1,0,2$ e 0,4 $\mu \mathrm{m}$. O efeito da exposição contínua de nicotina na reprodução de fibroblasto foi determinado pela incubação de culturas celulares em meio contendo nicotina por mais de 48 horas. A toxidade residual foi determinada pela préincubação de células com nicotina por 1 a 6 horas. Suspensões de HGF e concentrações aumentadas de nicotina foram colocadas juntas para determinar o efeito na inserção. Os resultados mostraram um maior efeito da nicotina na inserção dos HGF, com maior número de células de inserção com o aumento das concentrações de nicotina, comparados ao controle. Baixas concentrações de nicotina tiveram efeito estimulatório na replicação celular, enquanto altas concentrações de nicotina pareceram não ter efeito significante na reprodução dos fibroblastos gengivais humanos.Os resultados revelaram que a nicotina aumenta a capacidade de adesão dos fibroblastos, porém, em baixa concentração estimularia a proliferação e em concentrações maiores não pareceu ter efeito significativo. Os autores ainda relataram que a resposta fibroblástica pode persistir, mesmo após exclusão da droga.

O estudo de JAMES et al. ${ }^{59}, 1999$, investigaram os efeitos da nicotina e cotinina na inserção e crescimento dos fibroblastos derivados de ligamento periodontal humano (PDL). Culturas primárias foram preparadas da raiz de pré-molar extraído. Culturas foram expostas ao meio de cultura 
suplementado com: 1) soro de bezerro fetal a 15\% (FCS) somente; 2) FCS a $1 \%$ somente; 3 ) FCS a $1 \%$ e nicotina (escala de concentração $5 \mathrm{ng} / \mathrm{ml}$ para $10 \mathrm{mg} / \mathrm{ml}$ ); ou 4) FCS a $1 \%$ e cotinina (escala de concentração $0,5 \mathrm{ng} / \mathrm{ml}$ para $10 \mu \mathrm{g} / \mathrm{ml}$ ). Os autores encontraram que a nicotina inibiu significantemente a inserção e o crescimento de fibroblastos em concentrações $>0,5 \mathrm{mg} / \mathrm{ml}$ e $>1 \mathrm{mg} / \mathrm{ml}$. A cotinina na concentração mais alta $(10 \mu \mathrm{g} / \mathrm{ml})$, pareceu inibir a inserção e o crescimento de fibroblastos mas, não foi estatisticamente significante. Conclusivamente, os produtos do tabaco inibiram a inserção e o crescimento do fibroblasto do ligamento periodontal humano. Os autores relataram que essas alterações poderiam explicar parcialmente a função dessas substâncias na progressão da periodontite.

CHECCHI et al. ${ }^{28}, 1999$, objetivaram examinar os efeitos da nicotina nos fibroblastos gengivais humanos (HGF) "in vitro", as diferenças entre fumantes que consumiam mais de 10 cigarros por dia por um período de pelo menos 5 anos em relação a não-fumantes, e diferenças entre pacientes de diferentes idades. Quinze pacientes divididos em 4 grupos participaram do estudo, sendo 4 fumantes $\leq 25$ anos; 4 não-fumantes $\leq 25$ anos;3 fumantes $\geq 40$ anos e 4 não-fumantes $\geq 40$ anos. A nicotina foi testada em 3 concentrações diferentes:6 $\mu \mathrm{g} / \mathrm{ml} ; 60 \mu \mathrm{g} / \mathrm{ml}$ e $600 \mu \mathrm{g} / \mathrm{ml}$. As biópsias para avaliar os fibroblastos foram obtidas através de procedimentos cirúrgicos periodontais. O teste vermelho neutro(NR) foi usado para estudar a viabilidade celular e o teste Hoeschst para avaliar a proliferação celular. 
Após 48 horas de exposição à nicotina, os autores encontraram que 600 $\mu \mathrm{g} / \mathrm{ml}$ de nicotina era altamente citotóxica para HGF de todos os grupos, com significantes reduções da proliferação e viabilidade de células quando comparadas ao controle. Em relação à comparação entre grupos de mesma idade, foi encontrado que em HGF não tratados de fumantes $\leq 25$ anos versus não-fumantes $\leq 25$ anos, a proliferação celular, mas não a viabilidade, foi aumentada em fumantes. Em fumantes e não-fumantes $\geq 40$ anos, a viabilidade e proliferação de células controle estiveram aumentadas em fumantes. HGF de não-fumantes $\leq 25$ anos, quando expostos a 600 $\mu \mathrm{g} / \mathrm{ml}$ de nicotina tiveram menos viabilidade e proliferação do que HGF de fumantes de mesma idade. Quando comparados grupos de diferentes idades, o grupo de fumantes com HGF não tratados, tiveram similar viabilidade e proliferação, em relação à idade, mas $600 \mu \mathrm{g} / \mathrm{ml}$ de nicotina matou mais HGF em fumantes $\leq 25$ anos do que em fumantes $\geq 40$ anos. Em não-fumantes $\leq 25$ anos HGF não tratados replicaram menos, mas não foram menos viáveis do que $\geq 40$ anos. O estudo concluiu que a história de fumar e idade do paciente poderiam ser relevantes para avaliação final dos resultados, desde que HGF de fumantes são menos sensitivos à nicotina do que HGF de não-fumantes, e células de doadores mais velhos são mais resistentes à nicotina em relação às de doadores jovens.

GIANNOPOULOU; GEINOZ; CIMASONI ${ }^{41}, 1999$, examinaram o efeito da nicotina nas várias funções do fibroblasto do ligamento periodontal (PDLF): proliferação, inserção, produção de fosfatase alcalina e 
quimiotaxia. Foram testadas concentrações de nicotina, variando de $5 \mathrm{ng} / \mathrm{ml}$ a $250 \mu \mathrm{g} / \mathrm{ml}$. A proliferação das células teve uma inibição dependente da dose observada com concentrações $\geq 100 \mathrm{ng} / \mathrm{ml}$. Resultados similares foram observados, quando estudada a inserção das células na superfície plástica. A inibição da inserção foi até mesmo mais evidente após 6 horas de incubação das células com nicotina. A atividade da fosfatase alcalina foi também significantemente decrescida, quando relacionada à concentração. Finalmente, a quimiotaxia de PDLF foi inibida quando relacionada à dose. $\mathrm{O}$ grau de inibição variou de $15 \%$ com a concentração mais baixa de nicotina (50 ng/ml), para quase $90 \%$ com a mais alta $(5 \mu \mathrm{g} / \mathrm{ml})$.Através destes resultados, os autores demonstraram que a nicotina pode ter efeitos adversos diretos nas várias funções das células periodontais, inibindo a proliferação, inserção, produção de fosfatase alcalina, produção e migração dos fibroblastos do ligamento periodontal humano. Estes achados sugeriram um prejuízo no sistema de defesa do hospedeiro contra a progressão de periodontite. Isso poderia explicar, pelo menos em parte, o aumento da incidência e severidade das doenças periodontais em usuários crônicos de tabaco.

\subsection{Influência do tabaco na condição periodontal}

PINDBORG ${ }^{89}, 1947$, relacionaram fatores como a dieta, cálculo, cárie, restaurações e fumo na etiologia e prevalência das doenças periodontais. Com o objetivo de analisar a existência da relação do fumo com a GUNA, os autores examinaram experimentalmente $1400^{47}$ indivíduos 
e acima de 5600 dois anos mais tarde ${ }^{49}$, concluindo que existia relação entre o consumo de tabaco e depósito de cálculo; o fumo foi um fator na GUNA; houve aumento de depósito de cálculo e gengivite; e aparentemente o tabaco teve efeito "per se" nos tecidos de fumantes.

ARNO et al. ${ }^{5}, 1958$, estudaram 1346 indivíduos de 25 a 55 anos e, constataram que havia relação significante entre consumo de tabaco e presença de gengivite, depois de serem avaliados individualmente por sexo, ocupação, higiene e idade. Num estudo subseqüente, ARNO et al. ${ }^{6}$ 1959, examinaram 728 homens entre 21 e 45 anos e determinaram, radiograficamente, um aumento de perda óssea com o aumento do uso do tabaco, sugerindo que o consumo do mesmo é um fator que complica a doença periodontal, pois exerce efeito "per se" no osso periodontal.

No ano de 1968, SOLOMON; PRIORE; BROSS ${ }^{107}$ avaliaram 9561 pacientes entre 20 e 79 anos, em relação à condição periodontal entre nunca fumantes e fumantes, usando medidas de recessão gengival e reabsorção do osso alveolar. A prevalência de doença periodontal foi maior em fumantes. Nos grupos mais jovens, o alto índice de doença periodontal em mulheres assemelhou-se ao dos homens. Já em grupos mais velhos, a presença da doença periodontal em fumantes femininas assemelhou-se aos não-fumantes. Foi constatado que esta semelhança estaria relacionada à quantidade de cigarros fumados. Isto parecia relatar o fato de que as mulheres na população estudada com mais de 40 anos fumavam menos e 
por menos tempo do que as menores de 40 anos. Não houve diferença entre pacientes femininas e masculinos não-fumantes. Os achados desse estudo indicaram que indivíduos fumantes tiveram maior prevalência de doença periodontal em relação aos não-fumantes, quando equacionados por sexo e idade.

ALEXANDER $^{4}, 1970$, apud RIVERA ${ }^{100}, 1986$, estudou a condição gengival de 400 indivíduos maiores de 18 anos. Não-fumantes tiveram significativamente menos cálculo e menos inflamação gengival que fumantes, enquanto as diferenças na média da placa não foram significantes.

SHEIHAM $^{104}$, em 1971, avaliou a relação da doença periodontal e higiene bucal entre fumantes e não-fumantes. Foram examinados mais de 3000 indivíduos em grandes indústrias inglesas e irlandesas, em relação à quantidade de cálculos e nível de higiene oral. O estudo constatou que nos fumantes, quantidade de cálculo e níveis de inflamação gengival foram maiores. Indivíduos que fumavam acima de meia carteira de cigarro por dia tinham maior prevalência de doença periodontal severa e pior higiene oral. Quando indivíduos equacionados pelo nível de higiene oral foram comparados em relação à severidade de doença periodontal, não foram encontradas diferenças estatisticamente significantes entre fumantes e nãofumantes. 
PREBER; KANT ${ }^{95}$, 1973, apud RIVERA ${ }^{100}, 1986$, avaliaram 193 indivíduos com 15 anos de idade, determinando que higiene oral e status gengival foram piores entre fumantes. Contudo, em grupos com a mesma higiene oral, não houve diferenças evidentes.

BASTIAAN; WAITE ${ }^{12}, 1978$, estudaram a hipótese de que pacientes fumantes tinham uma taxa mais rápida de deposição de placa e desenvolvimento de gengivite. A proporção entre bactérias Gram positivas e Gram negativas também foi avaliada entre fumantes e não-fumantes. Vinte sujeitos participaram do estudo, com idade entre 17 e 29 anos, apresentando sinais clínicos mínimos de inflamação gengival e ausência de doenças sistêmicas. A média de cigarros fumados era de 16 cigarros/dia. Após a remoção inicial de depósitos, as medidas de higiene oral foram negligenciadas por 10 dias. Os níveis de placa e status gengival foram avaliados nos dias 3,7 e 10. As amostras de placas foram coradas pela técnica Gram e examinadas microscopicamente. Os autores relataram que os níveis de placa pareceram ser mais altos em fumantes do que em nãofumantes mas, as diferenças não foram estatisticamente significantes. Nenhuma diferença consistente foi evidente no status gengival dos dois grupos. A análise microbiológica demonstrou um aumento estatisticamente significante no terceiro dia, da porcentagem de bactéria Gram-positiva em relação à Gram-negativa nos fumantes, quando comparados aos nãofumantes. No entanto, essas diferenças não foram mantidas nas amostras de placa realizadas após o terceiro dia. 
MODEER; $\quad$ LAVSTEDT; $\quad \mathrm{AHLUND}^{80}, 1980, \quad$ apud RIVERA $^{100}, 1986$, examinaram 232 crianças escolares entre 13 e 14 anos em relação ao acúmulo de placa/gengivite em fumantes. Os fumantes tiveram aumento de acúmulo de placa e inflamação gengival quando comparados a não-fumantes. Contudo, quando a higiene oral era equacionada, não havia diferença significativa.

PREBER; KANT; BERGSTRÖM ${ }^{96}, 1980$, num estudo com adultos jovens; média de idade 21,9 anos, compararam a higiene oral e status periodontal entre fumantes e não-fumantes. Eles constataram que os fumantes apresentaram maior severidade de gengivite e maior índice de placa que não-fumantes mas, o mesmo número de bolsas profundas e perdas ósseas que não-fumantes. Esses achados similares entre os grupos, poderiam ser considerados como um fator resultante da pouca idade dos participantes do que dos parâmetros usualmente associados ao avanço da doença em pacientes mais velhos.

FELDMAN; BRAVACOS; $\operatorname{ROSE}^{38}, 1983$, estudaram a associação entre diferentes produtos de tabaco (cigarro, charuto/cachimbo) e índices de doença periodontal, nos indivíduos fumantes e não-fumantes do Veterans Administration Hospital. Índices clínicos incluíram depósitos de cálculo, acúmulo de placa, inflamação gengival, profundidade de bolsa periodontal, perda óssea alveolar e mobilidade dentária. Ambos os grupos de fumantes tiveram maior depósito de cálculo porém, foi maior em fumantes 
de cigarro. Quantidade menor de placa foi detectada no grupo de fumantes em relação a não-fumantes mas, foi levemente menor nos fumantes de cigarro. Não houve diferença na inflamação gengival e mobilidade dental entre os grupos. Foi observado que os fumantes de cigarros apresentavam bolsas mais profundas e perdas ósseas maiores, quando comparados aos outros dois grupos. Os autores sugeriram que poderia haver um efeito sistêmico relacionado ao tabaco, induzindo à perda óssea.

BERGSTRÖM; FLODERUS-MYRHED ${ }^{19}, 1983$, investigaram 164 pares de gêmeos suecos, baseados na presença de sangramento gengival. Em cada par de gêmeos, um dos indivíduos era fumante pesado e o outro fumante leve ou não-fumante. Foram analisados o sangramento, índice de placa, altura óssea alveolar e perda dentária. Foi encontrado um maior grau de perda óssea e dentária no grupo de fumantes pesados. A propensão ao sangramento aumentou com o aumento no índice de placa nos não-fumantes. O mesmo não foi relatado nos fumantes, sugerindo que a visão comum segundo a qual a quantidade crescente de placa levava a uma maior probabilidade de sangramento, não vale para fumantes. 0 sangramento gengival foi menor no grupo de fumantes pesados, sugerindo uma ação vasoconstritora do fumo ao nível gengival. Os autores constataram que a validade do sangramento como sinal e sintoma de doença periodontal pode ser reduzida em conseqüência do fumo. 
A relação de variáveis clínicas como sangramento e eritema gengival, profundidade de sondagem e índice de placa foram estudadas entre fumantes e não-fumantes por PREBER; BERGSTRÖM ${ }^{92}, 1985$. Participaram do estudo 20 pacientes com periodontite moderada a avançada, com idade entre 35 e 50 anos; sendo 10 não-fumantes e 10 fumantes de pelo menos 20 cigarros/dia por no mínimo 15 anos. O sangramento gengival e a profundidade de sondagem foram obtidos, utilizando-se sonda periodontal eletrônica de pressão controlada (60g). Os autores relataram que fumantes mostraram sangramento à sondagem significativamente menor em relação a não-fumantes.

Com o objetivo de investigar a influência de fumar cigarro no desenvolvimento da gengivite entre fumantes e não-fumantes, BERGSTRÖM; PREBER ${ }^{21}, 1986$, induziram gengivite experimental em um grupo de 20 estudantes de Odontologia,10 dos quais fumantes usuais. Os fumantes eram periodontalmente sadios, tinham média de idade de 28,4 anos, fumavam há pelo menos 4 anos e consumiam de 10-20 cigarros por dia. Foi solicitado que fumassem 1 cigarro 1 hora antes da investigação. Os não-fumantes tinham média de 27,8 anos. A investigação compreendeu 4 semanas de abstenção de higiene oral na região antero-inferior. Nas outras áreas da dentição, a higiene oral foi mantida. Os parâmetros clínicos estudados foram a quantidade de placa, o sangramento gengival à sondagem, vermelhidão e exsudato gengival. Os registros foram realizados nos dias $0,7,14,21$ e 28 durante o experimento, e após 35 e 42 dias do 
experimento. Os resultados demonstraram que a taxa de formação da placa foi similar em ambos os grupos. No entanto, fumantes demonstraram uma reação inflamatória gengival menos pronunciada, quando comparados aos não-fumantes. Com relação ao sangramento e vermelhidão gengival, a reação em fumantes foi significantemente menor do $14^{\circ}$ ao $28^{\circ}$ dia e a quantidade de exsudato gengival foi significantemente menor do $21^{\circ}$ ao $28^{\circ}$. As diferenças entre os grupos tenderam a aumentar com o tempo. Segundo os autores, esses resultados sugeriram que a resposta gengival inflamatória, pelo acúmulo de placa, pode ser suprimida sob a influência de fumar cigarros.

BERGSTRÖM $^{14}, 1990$, estudou se um padrão de higiene oral habitual e a compreensão de um novo método são diferentes em fumantes e não-fumantes e a influência de fumar cigarro na expressão de gengivite clínica sob um controle de higiene oral experimental. O grupo de estudo compreendeu 68 pacientes de 21-60 anos de idade. Destes, 40 eram nãofumantes e 28 fumantes habituais com média de consumo de 14,6 cigarros ao dia. A média de idade entre fumantes foi de 43,6 e nos não-fumantes de 42,4. O programa incluiu higiene oral com escova dentária elétrica por 12 meses. A limpeza oral foi avaliada de acordo com o índice de porcentagem de placa e gengivite e de acordo com a porcentagem de locais de sangramento. A colaboração com o programa de higiene oral foi similar entre fumantes e não-fumantes, $40 \%$ e $42 \%$ respectivamente. O índice de placa antes do início do experimento (na linha base) foi muito similar em fumantes 
e não-fumantes e permaneceu assim durante o curso da investigação(depois de 1,3 e 12 meses do experimento). Com o andamento do programa de higiene oral, o índice de placa decresceu em ambos os grupos. No início da investigação o índice de placa era de $47,8 \%$ e $51,0 \%$, passando para $22,7 \%$ e $27 \%$,para fumantes e não-fumantes, respectivamente. Os autores relataram não haver diferença estatisticamente significante entre os dois grupos em relação ao índice de placa. Independente da similaridade no índice de placa, o sangramento gengival foi significantemente mais baixo em fumantes $(16,7 \%)$ do que em não-fumantes $(30,25 \%)$ desde o início da investigação, continuando estatisticamente significante até o final. Os resultados sugeriram que fumantes e não-fumantes não diferem com respeito à higiene oral habitual ou novos programas de higiene. Em fumantes, no entanto, a expressão da gengivite clínica na resposta à placa foi suprimida.

GOULTSCHIN et al. ${ }^{43}, 1990$, compararam fumantes e nãofumantes em relação aos níveis CPITN (Commumty Periodontal Index of Treatment Needs). Participaram da pesquisa 344 indivíduos de um Hospital de Jerusalém, dos quais 154 homens e 190 mulheres. O limite de idade para homens ficou entre 18 e 74 anos (média de 41 anos) e de 17 a 66 anos para as mulheres (média de 39 anos). Os indivíduos responderam questionários sobre a saúde geral, incluindo questões de fumo. Os fumantes foram questionados sobre o número de cigarros fumados por dia. Os exames clínicos incluíram taxação de acordo com CPITN, usando sondagem 
periodontal. Foram avaliados 6 segmentos de cada boca. Quando menos de 2 dentes funcionais estavam presentes, o sextante era definido como edêntulo. Cada sextante foi determinado de acordo com a saúde encontrada. Quando nenhuma patologia era encontrada, o CPITN era igual a zero; quando havia gengivite e o sangramento era induzido por sondagem $($ CPITN $=1)$; com cálculo, supra ou subgengival $($ CPITN $=2)$; com bolsas superficiais de 4 para $5 \mathrm{~mm}(\mathrm{CPITN}=3)$, ou bolsas de $6 \mathrm{~mm}$ ou mais(CPITN=4). Não-fumantes apresentaram melhor saúde periodontal e bolsas mais rasas. Não-fumantes tiveram melhor saúde periodontal do que fumantes e houve uma redução no índice de sangramento gengival em fumantes. Os autores atribuíram este último achado a uma redução no fluxo sangüíneo gengival provocado pela nicotina, e sugeriram que os danos causados pelo cigarro deveriam ser incluídos em programas educativos.

BERGSTRÖM; ELIASSON; PREBER ${ }^{18}, 1991$, a fim de elucidar a hipótese de uma influência direta do fumo na saúde periodontal, estudaram a associação entre perda de osso periodontal interproximal em higienistas dentários suíços com boa saúde bucal. O estudo incluiu 210 indivíduos entre 24 a 60 anos, dos quais 30\% fumantes, 32\% fumantes ocasionais e 38\% não-fumantes. A média de idade foi de 33,6 em fumantes e de 36,7 em não-fumantes. A média de consumo entre fumantes foi de 15,0 $\pm 5,9$ cigarros/dia durante um tempo de 10,8 anos a 16,5 anos.A perda óssea interproximal foi mensurada pela distância da junção cemento-esmalte (CEJ) até o septo interdental (IS), através de radiografias interproximais. Os 
resultados revelaram que a distância CEJ -IS foi significativamente maior para fumantes $(1,71 \pm 0,08 \mathrm{~mm})$, quando comparada a fumantes ocasionais $(1,55 \pm 0,05 \mathrm{~mm})$ e não-fumantes $(1,45 \pm 0,04 \mathrm{~mm})$. Esta diferença entre fumantes e não-fumantes com boa higiene oral foi estatisticamente significante. A presença de cálculo foi examinada radiograficamente nos mesmos locais da mensuração óssea. A higiene oral sistematizada foi avaliada em 19 indivíduos: 8 fumantes e 11 não-fumantes. A média no índice da placa(Silness \& Löe) foi de 0,28 e 0,33 para fumantes e não-fumantes, respectivamente, não sendo estatisticamente significativas. Os autores relataram que a relação entre CEJ-IS, fumo e idade, foi estatisticamente significante entre fumantes e não-fumantes. Na relação entre CEJ -IS e consumo/duração do fumo, concluíram que a distância CEJ - IS foi maior para fumantes com maior consumo e maior duração do vício. A diferença entre fumantes com exposição < 100 cigarros/ano e aqueles com > 200 cigarros/ano foi estatisticamente significante. Este aumento foi mais pronunciado em fumantes usuais do que em fumantes ocasionais. Os autores concluíram haver evidências de que o fumo afeta a parte mineral do tecido ósseo, e que a perda progressiva do osso mineral é maior em fumantes. Que este poderia ser um argumento relacionando a influência do fumo nos tecidos periodontais com a infecção da placa, porém, este estudo em indivíduos com boa higiene oral mostrou uma maior perda óssea em fumantes do que em não-fumantes, sugerindo influência direta do fumo na saúde periodontal independentemente da infecção da placa. Ainda, os resultados das análises dos cálculos radiográficos mostraram que $92 \%$ dos 
indivíduos não apresentaram cálculo em nenhuma superfície dentária, não sugerindo relação entre cálculo e fumo.

STOLTENBERG et al. ${ }^{109}, 1993$, realizaram estudo sobre associação entre cigarro, bactérias patogências e condição periodontal. Foram examinadas as superfícies proximais de todos os dentes do sextante superior de 615 adultos, em relação à placa, ao cálculo, à gengivite e à sondagem. Cento e vinte e seis não-fumantes e 63 fumantes, respectivamente, com a mesma idade, sexo, placa e cálculo formaram um grupo acaso dentro do grupo original. Foram comparados os parâmetros clínicos e a microbiota oral nestes dois grupos. Os autores encontraram cinco vezes mais bolsas $\geq 3,5 \mathrm{~mm}$ nos fumantes e não houve diferenças na microbiota de ambos os grupos. Não houve diferenças significativas em relação ao percentual de microorganismos Gram -negativos (A. Actinomycetemcomitans, B. gingivalis, B. intermedius e B. forsythus) em bolsas profundas.

O efeito na mudança do hábito de fumar, foi investigado longitudinalmente por BOLIN et al. ${ }^{25}, 1993$, em 349 pacientes, analisando-se o nível da crista óssea alveolar. Foram utilizadas radiografias periapicais, comparativamente, realizadas em 1970 e 1980. Os indivíduos da pesquisa teriam que apresentar pelo menos 20 dentes. A perda óssea neste período foi medida, utilizando-se como referências altura óssea e comprimento radicular. A perda óssea marginal em não-fumantes ficou com média de 
$3.9 \%$ do comprimento da raiz, enquanto nos fumantes foi de $6.0 \%$.Os indivíduos que ao longo do experimento deixaram de fumar tiveram média de perda óssea de 4,4\%. Esta perda foi significativamente menor quando comparada à dos fumantes usuais. Os autores constataram a existência de interação entre fumo e índice periodontal e que deixar o hábito de fumar, suspende a progressão dos efeitos desfavoráveis sobre o tecido ósseo. Além disso, uma tendência dose-dependente foi achada e quase desapareceu, quando houve controle para o índice periodontal.

A relação entre fumo e doença periodontal foi investigada por LINDEN e MULLALEY ${ }^{69}$, em 1994. Participaram da pesquisa 82 técnicos em higiene dental, com idade entre 20 e 33 anos. Destes indivíduos, 21 eram fumantes que consumiam, em média, 15,4 cigarros/dia por um tempo médio de 11,8 anos. O nível de placa bacteriana foi semelhante entre os grupos. Fumantes apresentaram maior número de cálculos subgengivais, maior profundidade à sondagem, maior número de bolsas e perda de inserção periodontal com conseqüente maior prevalência de periodontite estabelecida. Os autores concluíram que o cigarro é um fator determinante da presença de destruição periodontal em indivíduos na faixa etária examinada.

A fim de investigar o grau de associação entre o hábito de fumar e a perda de inserção periodontal, GONZÁLES et al. $^{42}, 1996$, utilizaram a cotinina para medir os níveis de nicotina no soro sangüíneo e 
correlacionar os níveis séricos deste metabólito com a doença periodontal. Setenta e nove indivíduos com periodontite, entre 25 e 64 anos de idade participaram do estudo por um período de um ano. Os parâmetros clínicos utilizados foram: altura gengival, profundidade de sondagem de bolsa periodontal, nível de inserção clínica e altura da crista óssea alveolar. As amostras de soro foram analisadas pela quantidade de cotinina, através do método ELISA, sendo a diferença dos níveis de cotinina estatisticamente significantes entre os grupos. Os resultados indicaram que os níveis de cotinina sérica, usados como indicador bioquímico para fumantes, estão correlacionados com a severidade da perda de inserção periodontal. O estudo mostrou que os níveis de cotinina são estáveis por todo tempo, e que tais níveis relacionam-se positiva e significativamente com a doença periodontal crônica.

AXELSSON; PAULANDER; LINDHE , 1998, em estudo epidemiológico examinaram a condição periodontal e os hábitos de fumar de 1093 indivíduos, por faixa etária de 35, 50, 65, e 75 anos. As variáveis clínicas foram: número de indivíduos edêntulos, número de dentes faltantes, nível de inserção à sondagem, envolvimento de furca, escores CPITN, placa e taxa de secreção salivar estimulada (SSSR). Os participantes responderam questionário sobre hábitos de tabaco, higiene oral, dieta, etc. A porcentagem de fumantes com $35,50,65$, e 75 anos de idade foi $35 \%, 35 \%$, $24 \%$ e $12 \%$, respectivamente. Nos indivíduos de 75 anos, $41 \%$ dos fumantes eram edêntulos comparados aos $35 \%$ de não-fumantes. A diferença no 
número de dentes faltantes entre fumantes e não-fumantes foi $0,6,1,5,3,5$ e 5,8 nos 4 grupos de idade. Fumantes tiveram média de perda de inserção à sondagem maior em todas as idades. As diferenças entre os fumantes e não-fumantes na média do nível de inserção foi de $0,37,0,88,0,85$ e 1,33 $\mathrm{mm}$ em 35, 50, 65, e 75 anos de idade, respectivamente. As variáveis relacionadas ao CPITN foram maiores em fumantes de todas as faixas etárias, com exceção do índice de placa e higiene oral, que foram similares entre fumantes e não-fumantes. Foi concluído que fumar é um indicador de risco significante para perda dentária e perda de inserção.

BERGSTRÖM; ELIASSON; DOCK ${ }^{17}, 2000$, objetivaram avaliar a saúde periodontal em uma população de músicos profissionais com bons hábitos de higiene oral, de nível sócio-econômico médio. A influência do comportamento de fumar na condição de saúde periodontal foi clinicamente e radiograficamente estudada em 257 adultos dentados, entre 20-69 anos de idade, incluindo 50 fumantes usuais, 61 fumantes ocasionais e 133 nãofumantes. As variáveis clínicas investigadas foram realizadas em locais doentes $\geq 4 \mathrm{~mm}$, sendo realizados índices de sangramento gengival e de placa. Em adição, a altura do osso periodontal foi radiograficamente avaliada como uma porcentagem do comprimento de raiz dental. Todas as variáveis foram baseadas no exame de boca total, incluindo todos os dentes. As observações indicaram uma condição de saúde periodontal inferior associada ao fumo. Isto foi evidenciado por uma freqüência significantemente maior de locais doentes e uma redução significantemente 
maior de altura óssea periodontal nos fumantes usuais, quando comparados a não-fumantes. A condição de fumantes ocasionais foi intermediária entre os fumantes usuais e não-fumantes, sugerindo que os fumantes ocasionais que pararam de fumar, tiveram uma condição de saúde periodontal melhor do que os fumantes usuais, embora pior do que os não-fumantes. Os achados de que fumantes ocasionais exibiram menos doença do que os fumantes usuais, sugerem que parar de fumar pode ser benéfico e diminui os efeitos desagradáveis provocados pelo fumo, permitindo uma normalização em direção às condições de não-fumantes. A exposição pesada ao fumo foi consistentemente associada com uma condição mais severa do que uma exposição leve, sugerindo que a relação entre a exposição do fumo e a morbidade periodontal é dependente da dose. Os autores concluíram que as observações presentes identificaram um impacto negativo do fumo na saúde periodontal e proporcionaram evidência de que o fumo de tabaco é um risco evitável para doença periodontal.

HAFFAJEE; SOCRANSKY ${ }^{52}, 2001$, examinaram características clínicas de doença periodontal e padrões de perda de inserção em sujeitos com periodontite do adulto, em fumantes usuais, ex-fumantes e nunca fumantes. Participaram do estudo 289 indivíduos entre 20 e 86 anos de idade com o mínimo de 20 dentes e com 4 sítios com profundidade de bolsa e/ou um nível de inserção $>4 \mathrm{~mm}$. O índice de placa, gengivite, sangramento à sondagem, supuração, profundidade de sondagem e nível de inserção foram realizados em 6 locais por dente, em todos os dentes, excluindo-se os 
terceiros molares. Os indivíduos foram classificados pela história do fumo e por idade, $<41,41-49,>49$. O estudo mostrou que fumantes usuais tiveram significantemente mais perda de inserção, dentes faltantes, bolsas mais profundas e menos locais exibindo sangramento à sondagem do que ex ou nunca fumantes. Os fumantes usuais tiveram maior perda de inserção em relação aos outros dois grupos. O nível de inserção média em não-fumantes $<41$ anos e fumantes usuais $>49$ anos foi respectivamente 2,49 e $4,10 \mathrm{~mm}$. Os perfis de nível de inserção de boca total indicaram que fumantes tinham mais perda de inserção do que aqueles que nunca fumaram, particularmente nos sítios palatinos superiores e nos dentes antero-inferiores. Os autores concluíram que fumantes usuais tiveram evidência de doença periodontal mais severa do que ex ou nunca fumantes; a diferença no nível de inserção média em locais individuais entre fumantes e nunca fumantes, não foi uniforme e as maiores perdas de inserção observadas em sítios palatinos superiores e antero-inferiores sugeriram possibilidade de um efeito local do fumo do cigarro.

A proposta do estudo de JANSSON; HAGSTRÖM ${ }^{60}$, 2002, foi investigar a relação entre condição periodontal e a tendência de interromper o tratamento periodontal e determinar se esta relação difere significantemente entre fumantes e não-fumantes. A investigação foi conduzida como um estudo retrospectivo em uma amostra de 325 pacientes encaminhados para tratamento. Com o objetivo de investigar algumas correlações entre o status periodontal e fumo ou tratamentos periodontais 
interrompidos, análise de regressão múltipla foi adotada. A idade média da amostra foi 49,7 anos e a maioria eram mulheres (57\%). A freqüência relativa de fumantes foi $52 \%$. A freqüência relativa de interrupção de tratamento periodontal foi $26 \%$ para não-fumantes e $31 \%$ para fumantes. Fumantes que interromperam o tratamento periodontal após a reavaliação tiveram maiores profundidades de sondagem em relação aos que não interromperam o tratamento, independentemente do hábito de fumar. Os resultados demonstraram que os indivíduos sem manutenção periodontal tiveram um maior risco de periodontite recorrente. Os autores afirmaram que o fumo é um fator de risco estabelecido de doença periodontal e fumantes têm alto risco de recorrência de periodontite durante a fase de manutenção. Ainda, que a ausência de controle periodontal e o fumo constituem fatores significantes para o risco de progressão de periodontite. Dessa maneira, reforçaram a importância de reduzir a freqüência do abandono de tratamento a fim de melhorar os prognósticos periodontais.

\subsection{Influência do tabaco na terapia periodontal}

PREBER; BERGSTRÖM ${ }^{92}, 1985$, investigaram as alterações na profundidade de sondagem de bolsas após o tratamento periodontal não cirúrgico em 75 pacientes entre 26 e 49 anos. Quarenta pacientes eram fumantes pesados (20 cigarros ou mais/dia) e 35 não-fumantes. Os pacientes tinham periodontite moderada à avançada. $89 \%$ das bolsas tinham profundidade de sondagem inicial de 4-6 $\mathrm{mm}$ e foram selecionadas para o estudo, nos elementos $16,12,24,36,32$ e 44 . O tratamento consistiu da 
instrução e motivação do paciente e debridamento de placas e cálculos pela instrumentação manual. O número de sessões por paciente foi de 7 ou 8 , e requereu em torno de 1 hora por sessão. $O$ tratamento foi concluído em 5 meses e a profundidade de sondagem foi anotada antes e após 1 mês do término da terapia. O Índice de placa foi reduzido ao mínimo em ambos fumantes $(P I=0,2)$ e não-fumantes $(P I=0,1)$ após o tratamento. Foi observada uma redução média na sondagem de profundidade de bolsa de $1,13 \mathrm{~mm}$ em fumantes e 1,23mm em não-fumantes, apesar de não estatisticamente significante. A pesquisa relatou menor redução na profundidade de sondagem em fumantes do que em não-fumantes para todas as regiões da dentição investigada e uma maior diferença entre os grupos para a região ântero-superior.

CUFF et al. ${ }^{30}, 1989$, realizaram um estudo "in vitro" em raízes de dentes de indivíduos fumantes, extraídos em conseqüência da doença periodontal. Através de análise cromatográfica, determinaram a presença de grande quantidade de nicotina nas superfícies radiculares. Sugeriram que a presença de nicotina no periodonto de inserção poderia prejudicar a regeneração periodontal, e explicaria uma resposta menos favorável a procedimentos não-cirúrgicos.

BAIN; MOY $^{9}, 1992$, avaliaram mais de 1200 implantes osseointegrados e encontraram mais osso tipo IV em fumantes severos do que em fumantes leves e não-fumantes, concluindo que o consumo 
excessivo de cigarros pode predispor os indivíduos à pobre qualidade óssea, e conseqüentemente, reduzir as taxas de sucesso para implantes dentais osseointegrados. No ano seguinte, os mesmos autores ${ }^{10}$,estudaram a associação entre as falhas dos implantes dentais e o hábito de fumar. 0 estudo revisou o resultado de 2194 implantes Branemark, colocados em 540 pacientes por um período superior a seis anos. A taxa total de fracasso de $5,92 \%$ foi consistente com outros estudos. Os critérios para a detecção de falhas foram a remoção dos implantes com mobilidade e mais de $50 \%$ de perda óssea detectada radiograficamente. Quando os pacientes foram divididos em fumantes e não-fumantes, descobriu-se uma porcentagem bem maior de fracassos ocorridos em fumantes $(11,28 \%)$ do que em nãofumantes $(4,76 \%)$. Tais diferenças, foram significativas para todas as áreas, exceto para a mandíbula posterior. Enquanto as taxas de fracasso decaíram com o aumento do comprimento dos implantes, taxas de falhas para cada extensão do implante foram consideravelmente mais altas em fumantes do que em não-fumantes. Os autores ressaltaram a atuação maléfica da nicotina na microvascularização, relacionando-a como o mecanismo mais provável na indução das falhas. A partir deste pressuposto e dos dados obtidos, os mecanismos possíveis de fracasso em fumantes foram discutidos e o protocolo para que o paciente parasse de fumar ao longo da fase cirúrgica dos implantes osseointegrados foi proposto.

O processo de reparo ósseo após a colocação de implantes osseointegrados em relação ao consumo de cigarros foi avaliado por 
JONES; TRIPLETT ${ }^{62}$, em 1992. Os autores concluíram que 10\% dos nãofumantes e $80 \%$ dos fumantes apresentaram problemas no reparo ósseo, demonstrando que o consumo de cigarros foi um fator fortemente associado com o prejuízo no processo de reparação óssea em implantes osseointegrados.

A incidência de falha em implantes osseointegrados em sua fase inicial, anterior à colocação das próteses, quando associada ao consumo de cigarro foi avaliada por DeBRUYN; COLLAERT ${ }^{33}$,em 1994. Quando a qualidade óssea foi similar entre fumantes e não-fumantes, houve taxa de insucesso de $9 \%$ nos fumantes versus $1 \%$ nos não-fumantes, sendo estatisticamente significante. Em fumantes em área com ótima qualidade óssea (osso tipo I) a taxa de insucesso chegou a $31 \%$. Por outro lado, apenas $4 \%$ dos implantes de pacientes não-fumantes se constituíram em falhas, neste caso, devido à pobre qualidade óssea (osso tipo IV).Concluiuse que o fumo é um fator de risco para implantes osseointegrados em sua fase inicial.

O estudo longitudinal de AH et al. ${ }^{1}$,em 1994, avaliou o efeito do fumo na resposta clínica à terapia periodontal cirúrgica e não cirúrgica entre fumantes e não-fumantes. Participaram da pesquisa 74 indivíduos adultos com periodontite moderada a avançada. Destes, 46 eram fumantes de no mínimo 10 cigarros por dia, com idade média de 42,5 anos e 28 eram nãofumantes com idade média de 46,2 anos. Os pacientes foram tratados de 
acordo com o design de boca dividida em 4 quadrantes, envolvendo as seguintes modalidades de tratamento: raspagem coronária (CS), raspagem e aplainamento radicular $(\mathrm{RP})$, raspagem e aplainamento radicular com retalho de Widman modificado, e raspagem e aplainamento radicular com retalho e cirurgia resseccional óssea (FO). Parâmetros clínicos avaliados incluíram profundidade de sondagem, nível de inserção à sondagem, nível de inserção horizontal em locais de furca, recessão, presença de placa supragengival e sangramento à sondagem. Os autores relataram 3 fases. Durante a fase I, os pacientes receberam instruções de higiene oral. Dentes do quadrante CS receberam apenas raspagem coronária e debridamento com instrumentos ultrassônicos e manuais. Os outros três quadrantes receberam raspagem e aplainamento radicular subgengival com ultrassom e curetas. Na fase II, os quadrantes foram submetidos à terapia cirúrgica. $\mathrm{Na}$ fase III, a terapia de manutenção consistiu de reforço de remoção de placa e instrumentação subgengival, exceto para o quadrante CS que recebeu apenas raspagem supragengival. A terapia de manutenção foi realizada trimestralmente por 6 anos. Os dados coletados foram: inicialmente, 4 semanas após a terapia de fase-I, 10 semanas após a terapia de fase-II e anualmente durante 6 anos de manutenção. A análise dos dados demonstrou que os fumantes exibiram significantemente menor redução de profundidade à sondagem e menor ganho do nível de inserção quando comparados a não-fumantes, imediatamente, após terapia ativa e anualmente, durante os 6 anos de manutenção. Os autores ainda relataram que uma maior perda do nível de inserção horizontal foi evidente em fumantes em cada exame anual durante a terapia de manutenção. Não 
houve diferenças entre os grupos nas alterações de recessão. Em geral, esses achados foram verdadeiros para os resultados após todas as 4 modalidades da terapia e foram mais pronunciadas na variável de profundidade de sondagem profunda $(\geq 7 \mathrm{~mm})$. A análise estatística demonstrou uma tendência para fumantes ter levemente mais placa supragengival e sangramento à sondagem. Os autores concluíram que fumantes não responderam tão bem quanto não-fumantes às terapias periodontais cirúrgicas e não cirúrgicas.

TONETTI; PINI-PRATO; CORTELLINI ${ }^{111}$,em 1995, realizaram um estudo retrospectivo sobre o efeito do cigarro na RTG com membrana de teflon. Vinte pacientes com 32 defeitos eram fumantes de mais de dez cigarros ao dia, e 31 eram não-fumantes com 39 defeitos. As medidas clínicas foram obtidas do fundo da bolsa, quando a membrana foi removida um ano depois. Os índices de placa foram sempre maiores em fumantes, apesar da higiene oral ser boa. Não houve diferença significativa no percentual de tecido ganho, quando a membrana foi removida. Porém, após um ano, os fumantes tiveram menor ganho de inserção em comparação aos não-fumantes. Uma correlação variável entre higiene oral e componentes infra-ósseos indicou que fumantes tiveram um fator a mais influenciando no resultado clínico. A análise final indicou que os fumantes apresentavam um risco significativamente maior a desencadear uma redução de ganho de inserção adquirida com a RTG. 
A possível relação entre fumo e o desenvolvimento de periimplantite foi avaliada por HASS et al. ${ }^{47}$,em 1996. Os autores avaliaram 421 pacientes e 1366 implantes. Cento e sete pacientes fumantes com 366 implantes apresentaram maior risco em desenvolver peri-implantite, quando comparados aos 314 pacientes não-fumantes com 1000 implantes. O estudo confirmou o papel deletério do fumo funcionando como co-fator local no prognóstico desfavorável em implantes, principalmente na maxila.

BOSTRÖM;LINDER;BERGSTRÖM ${ }^{26}, 1998$, fizeram um acompanhamento de 5 anos após cirurgia periodontal em 57 pacientes, dos quais 20 fumantes usuais, 20 fumantes ocasionais e 17 não-fumantes entre 37-77 anos ( média de 59,7 anos).O programa terapêutico consistiu de uma fase primária, sem cirurgia, incluindo instruções de higiene oral, raspagem e alisamento radicular. A segunda fase incluiu cirurgia com retalho de Widman modificado em sítios com lesões intra-ósseas persistentes. As regiões selecionadas para cirurgia foram radiografadas e avaliadas em relação ao nível ósseo periodontal. As características clínicas avaliadas foram placa supragengival, sangramento gengival, profundidade de bolsa e nível ósseo. Posteriormente, a ocorrência de patógenos Actinobacillus actinomycetemcomitans (Aa), Porphyromonas gingivalis (Pg) e Prevotella intermédia (Pi) e os níveis de fator alfa de tumor de necrose (TNF- $\alpha$ ) foram avaliados no fluido sulcular gengival (GCF). O índice de placa foi $28,5 \%$ na linha base e $32,9 \%$ posteriormente, indicando um bom padrão de higiene oral. O sangramento gengival foi $31,7 \%$ e $24,9 \%$, respectivamente, na linha 
base e posteriormente, sugerindo um nível baixo a moderado de inflamação gengival. Em regiões selecionadas para cirurgia, a profundidade de sondagem de bolsa decresceu significantemente de uma média de 5,6 mm para 4,3 mm e o nível ósseo aumentou significantemente de uma média de $62,5 \%$ para $67,5 \%$. Em termos de nível ósseo, o resultado foi menos favorável entre os fumantes comparado a não-fumantes. Houve uma predominância de fumantes exibirem perda do nível ósseo após os 5 anos de manutenção. Nenhuma associação significante foi encontrada entre o resultado terapêutico e a placa supragengival ou a ocorrência subgengival de patógeno. As associações entre os níveis GCF e TNF- $\alpha$ e profundidade de sondagem e nível ósseo não foram claras, contudo o nível de TNF- $\alpha$ foi significantemente elevado em fumantes.

RENVERT;DAHLÉN;WIKSTRÖN ${ }^{99}, 1998$, estudaram os efeitos clínicos e microbiológicos após seis meses de terapia periodontal não cirúrgica em fumantes e não-fumantes com profundidade de sondagem $\geq$ 6mm. Participaram da pesquisa 28 pacientes entre 40 e 60 anos, 13 fumantes( $\geq 15$ cigarros/dia) e 15 não-fumantes, com doença periodontal avançada não tratada. Os indivíduos receberam instruções de higiene oral e foram tratados com terapia periodontal não cirúrgica por um higienista dental. Valores da linha base com relação aos dados clínicos não diferiram significantemente entre os grupos. Após seis meses de terapia, o escore de sangramento de boca total entre os fumantes foi $36,5 \%$, quando comparado a $22,7 \%$ para não-fumantes. A profundidade de sondagem foi reduzida em 
1,9 $\mathrm{mm}$ para fumantes e 2,5 $\mathrm{mm}$ para não-fumantes. Esta diferença foi estatisticamente significante. $O$ nível do $P$. gengivalis $e$ do P.intermédia/nigrescens foi reduzido em ambos os grupos como comparado na linha base. No entanto, o A.actinomycetemcomitans demonstrou um leve aumento nos valores médios em 6 meses. Isto foi especialmente notável para os fumantes no qual este patógeno foi mais difícil de erradicar. Os autores concluíram que a resposta microbiológica encontrada no estudo, parece estar em conformidade com a resposta clínica, tendo pouca influência nos hábitos do fumo.

NOCITI Jr. et al. ${ }^{82}, 2002$, investigaram em estudo animal a influência da inalação intermitente de cigarro na osseointegração e nova formação óssea em implantes rosqueados. Quarenta Ratos machos Wistar foram incluídos no estudo. Após anestesia geral, a superfície da tíbia foi exposta, recebendo bilateralmente, implantes de 4,0 $\mathrm{mm}$ de comprimento e 2,2 $\mathrm{mm}$ de diâmetro. Os animais foram divididos em grupo 1, controle e grupo 2, expostos à inalação intermitente de fumaça de cigarros, contendo 13 mg de nicotina (10 cigarros) por 8 minutos, três vezes ao dia. Os animais de ambos os grupos foram sacrificados após 60 dias. O grau de osso em contato com implante $(\mathrm{BIC})$ e área óssea $(\mathrm{BA})$ contendo os implantes rosqueados foi mensurado na área óssea cortical I(zona A) e trabecular (zona B). Os autores notaram uma leve diferença no osso em contato com o implante (BIC) entre os grupos, mas não estatisticamente significante nem na zona cortical nem na trabecular. Em contraste, a área óssea (BA) 
próxima ao implante decresceu significativamente em ambas as áreas para o grupo $2(84,73 \%$ versus $79,85 \%$, na zona $A$, e $32,01 \%$ versus $20,71 \%$, na zona B nos grupos 1 e 2 respectivamente). Desta maneira, os autores concluíram que a inalação intermitente de fumaça de cigarro pode resultar em uma qualidade óssea pobre em volta de implantes de titânio inseridos em ratos.

Com o objetivo de comparar a associação entre fumantes e não-fumantes e o envolvimento de lesões em bifurcações de molares, MARTELLI Jr. et al. ${ }^{72}$, 2003, selecionaram 60 pacientes, 30 fumantes e 30 não-fumantes com idade entre 20 e 60 anos, que apresentavam no mínimo 15 dentes em cada arcada. Os pacientes foram avaliados clinicamente em relação aos primeiros e segundos molares inferiores e as lesões de bifurcação classificadas em três diferentes graduações I,II e III( HAMP et al.,1975), utilizando para tal, sonda Periodontal de Nabers. Além dos dados semiológicos e clínicos, foram incluídas informações relacionadas à quantidade de cigarros consumida por dia e à longevidade do hábito de fumar. Os resultados obtidos revelaram uma média de 13,53 cigarros/dia para fumantes. No sexo masculino ocorreu maior consumo diário e no feminino, a maior duração do hábito. A maior parte das lesões encontradas foi classificada como grau I, em ambos os grupos. A porcentagem de lesões foi maior nos pacientes fumantes, quando comparada a não-fumantes, tanto para valores absolutos como quando classificadas em diferentes graduações clínicas. 


\subsection{Tabagismo como fator de risco periodontal}

Com o intuito de investigar o cigarro como fator de risco para doença periodontal crônica,BERGSTRÖM ${ }^{13}, 1989$, avaliou pacientes admitidos na Escola de Odontologia de Estocolmo, durante os anos de 1980 a 1982. Os 134 pacientes foram separados por idade( 30,40 ou 50 anos), sexo e em fumantes e não-fumantes. A média geral de consumo de cigarro foi de 15,3 cigarros por dia. Variáveis periodontais foram a profundidade de sondagem $>4 \mathrm{~mm}$, índice gengival, e índice de placa. $\mathrm{O}$ índice gengival e de placa não diferiram entre os grupos. O autor encontrou uma taxa de risco de 2,5 para fumantes em relação à doença periodontal. Esses resultados sugeriram maior prevalência e severidade de doença periodontal em fumantes, sendo o hábito de fumar um fator de risco para doença periodontal crônica.

HABER et al. ${ }^{49}$, 1993, em estudo seccional, analisaram o papel do fumo como um fator de risco para periodontites em diabéticos(IDDM) e não diabéticos. Os pacientes foram divididos por idade de 19 a 30 e 31 a 40 anos e por sexo. O número de participantes foi de 227, dos quais 132 IDDM e 95 não diabéticos. 0 exame clínico incluiu mensuração de bolsa gengival (GPD), perda de inserção (AL), placa, sangramento à sondagem, vermelhidão gengival e supuração em 6 sítios dentários (mesio-vest., distovest., centro da vestibular, mesio-lingual, disto-lingual e centro da lingual) de todos os dentes, excluindo os $3^{\text {os }}$ molares. $\mathrm{O}$ indivíduo era classificado com periodontite positiva se possuísse ao mesmo tempo 1 sítio com $5 \mathrm{~mm}$ de 
bolsa(GPD) e 2mm de perda de inserção (AL). Para todas as análises, diabéticos e não diabéticos, foram avaliados separadamente, por idade e utilização de fumo (nunca, ocasionais, usuais). A prevalência de periodontite positiva entre não diabéticos de 19 a 30 anos foi menor em nunca fumantes e tendeu a aumentar com o consumo de cigarro e com a idade. Quando comparados sítios com GPD no grupo de 19 a 30 anos e 31 a 40 anos, o percentual foi maior em fumantes usuais comparado com fumantes ocasionais e nunca fumantes. Estas diferenças entre o grupo de 19 a 40 anos de fumantes usuais e nunca fumantes foram altamente significantes. Fumantes usuais tiveram uma proporção maior de bolsas de $5 \mathrm{~mm}$ do que os outros 2 grupos. O percentual de sítios com perda de inserção maior que $2 \mathrm{~mm}$ foi maior em fumantes usuais do que em nunca fumantes, sugerindo que a periodontite foi mais severa e comum em fumantes usuais do que em nunca fumantes. Entre 19 a 40 anos, não diabéticos e IDDM, as mulheres tiveram menor prevalência de periodontite do que os homens. Os autores relataram que como esperado, ambas, prevalência e severidade da doença, aumentaram com a idade. As associações entre fumantes usuais e condição periodontal na população de diabéticos foram similares aos não diabéticos e indicaram que fumantes usuais estavam associados com maior prevalência e aumento de periodontite severa, quando comparados a não-fumantes. Os riscos percentuais atribuídos à periodontite sugeriram que os fumantes representaram o grupo de maior risco periodontal e que o fumo poderia ser o fator de risco mais simples para a periodontite. Os autores sugeriram que uma substancial proporção dos casos de periodontite estava associada ao fumo de cigarro. 
BERGSTRÖM; PREBER ${ }^{22}$,1994, em publicação sobre o tabaco como fator de risco, revisaram conhecimentos sobre a influência do tabaco na saúde e doença periodontal. De acordo com os autores, estudos avaliaram pacientes com alto nível de higiene oral e confirmaram que existe associação entre tabaco e perda óssea radiograficamente, depois do controle da placa. Um número de investigações, usando diferentes populações e variedade de métodos de mensuração de sintomas e classificação da doença, acharam riscos similares relativos para a associação entre doenças destrutivas e o fumo. A associação do fumo com a microbiota patogênica foi negativa. Pacientes fumantes com doença severa não foram diferentes de outros não-fumantes em relação aos microorganismos. As terapias não cirúrgicas, raspagem e alisamento radicular profissional, redução de sangramento gengival e redução de bolsa periodontal, foram menos eficientes em fumantes, quando comparados aos não-fumantes. Os estudos a este respeito, tiveram limitações por serem relativamente curtos, 12 meses ou menos, com exceção, de um estudo que avaliou anualmente, por mais de 6 anos o tratamento. Os resultados indicaram pouca redução de bolsa, pouco ganho no nível de inserção, e maior perda nos níveis de inserção horizontal em furcas em fumantes. Estes resultados sugeriram maior discrepância entre pacientes fumantes e nãofumantes e maior risco de fracasso da terapia associada ao fumo. Este foi considerado fator marcante em doenças recorrentes. Outro estudo revisado, foi um sueco, relacionando doença periodontal e tabaco longitudinalmente, envolvendo pessoas entre 21 a 76 anos, com alto nível de educação e boa condição odontológica. Foram examinados 258 indivíduos em 1982 e 257 
em 1992. Fatores como a higiene oral foram similares entre os grupos nos dois períodos.Apesar do fato do nível de saúde oral ter melhorado nos últimos 10 anos, a condição nos fumantes foi significativamente inferior nos fumantes de1992. Os autores sugeriram que o fumo estava associado à progressão e falha no controle da doença e que foi vantajoso parar de fumar.

Os autores finalizaram a revisão, relacionando a associação da diminuição do fumo com a doença periodontal. Os resultados sugeriram que o aumento do fumo esteve associado ao aumento do risco de recessões gengivais em áreas expostas ao tabaco. Contudo, a ocorrência de bolsa periodontal ou formas severas de doença periodontal, pareceram não ser relatadas.

GROSSI et al. ${ }^{45}$, 1995, em estudo longitudinal com 1.361 indivíduos, 696 mulheres e 665 homens, entre 25 e 74 anos, constataram os vários problemas periodontais em fumantes. Na tentativa de delinear o potencial de risco para perda do osso alveolar, foram examinadas variáveis demográficas, sistêmicas e microbiológicas. Para o propósito da análise, a idade foi dividida em 5 décadas: 25 a 34; 35 a 44; 54,55 a 64,65 a 74, os sexos separados, assim como a raça (preta, branca ou outras que incluíram americanos nativos); a educação foi dividida em níveis (concluído o $3^{\circ} \mathrm{grau}$ ou menos); a renda familiar em moderada ou alta. A história de fumo incluiu número de cigarros fumados por dia e o número de anos fumados, resultando na quantidade de pacotes/ano (Packyears). $O$ número de Packyears observado foi de 1 a 150. Os indivíduos foram divididos em 5 categorias:1. não-fumantes;2. muito leves ou ocasionais ( $>$ o a 5,2 
packyears); 3 . leves (5,3 a 15,0 packyears); 4 . moderado (15,1 a 30,0 packyears); 5 fumantes pesados (30,1 a 150 packyears).Os resultados revelaram que a associação entre fumantes e perda óssea foi estatisticamente significante. Os fumantes foram associados com a severidade de perda óssea alveolar de maneira similar à associação com perda de inserção, ou seja, o aumento de perdas ósseas severas esteve diretamente relacionado ao aumento do consumo do fumo. O risco de perda óssea em fumantes foi, contudo, maior do que para perda de inserção. Os autores também inferiram sobre efeitos tóxicos do tabaco no periodonto, reduzindo a atividade funcional dos leucócitos e macrófagos, diminuindo a fagocitose dos leucócitos PMN e promovendo aumento na proporção de bactérias anaeróbicas na placa dental. Fumantes também foram associados à diminuição na absorção intestinal do cálcio e portanto, aumento da taxa de perda óssea em mulheres pós-menopausa saudáveis. Ainda, segundo os autores, a grande associação observada entre idade e severidade de perdas ósseas poderia ser explicada pelo efeito que a idade tem na redução da atividade de osteoblastos, resposta para mitoses e estimulação da formação e reparo ósseo.

A relação entre consumo do tabaco com doença periodontal foi relatada por MARTINEZ-CANUT; LORCA; MAGAN ${ }^{73}$, em 1995. O estudo mostrou que o aumento no número de cigarros fumados esteve relacionado com aumento na severidade da doença periodontal. Pacientes que fumavam menos de 10 cigarros por dia não apresentavam diferença significante, 
comparados a não-fumantes, considerando a perda de suporte periodontal. Por outro lado, fumantes que fumavam entre 10 e 20 cigarros ou mais por dia, apresentaram, comparados a não-fumantes, aumento de perda de inserção de $5 \%$ e 10\%, respectivamente. Contudo, o estudo não especificou a duração do hábito de fumar do grupo de fumantes.

AXELSSON; PAULANDER; $\quad$ LINDHE $^{7}, 1998$, em estudo epidemiológico examinaram a condição periodontal e os hábitos de fumar de 1093 indivíduos, por faixa etária de 35, 50, 65, e 75 anos. As variáveis clínicas foram: número de indivíduos edêntulos, número de dentes faltantes, nível de inserção à sondagem, envolvimento de furca, escores CPITN, placa e taxa de secreção salivar estimulada (SSSR). Os participantes responderam questionário sobre hábitos de tabaco, higiene oral, dieta, etc. A porcentagem de fumantes com $35,50,65$, e 75 anos de idade foi $35 \%$, $35 \%, 24 \%$ e $12 \%$, respectivamente. Nos indivíduos de 75 anos, $41 \%$ dos fumantes eram edêntulos, comparados aos $35 \%$ de não-fumantes. A diferença no número de dentes faltantes entre fumantes e não-fumantes foi $0,6,1,5,3,5$ e 5,8 nos 4 grupos de idade. Fumantes tiveram média de perda de inserção à sondagem maior em todas as idades. As diferenças entre os fumantes e não-fumantes na média do nível de inserção foram de 0,37, 0,88, 0,85 e 1,33 mm em 35, 50, 65, e 75 anos de idade, respectivamente. As variáveis relacionadas ao CPITN foram maiores em fumantes de todas as faixas etárias, com exceção do índice de placa e higiene oral, que foram similares entre fumantes e não-fumantes. Foi 
concluído que fumar é um indicador de risco significante para perda dentária e perda de inserção. 
3 Proposição

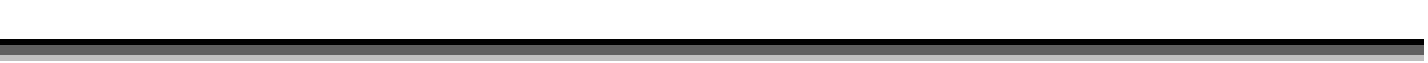




\section{Proposição}

Baseado nos aspectos abordados na literatura a respeito da inter-relação tabagismo-doença periodontal, este trabalho teve como objetivos:

1- Analisar comparativamente as condições periodontais entre fumantes e não-fumantes, utilizando parâmetros clínicos clássicos: profundidade de sondagem, recessão gengival, nível de inserção clínica, índice gengival, índice de placa e índice de sangramento gengival;

2- Analisar comparativamente as condições histomorfológicas do tecido conjuntivo gengival de área de bolsa periodontal de fumantes e não - fumantes;

3- Analisar comparativamente as condições histomorfométricas do tecido conjuntivo gengival de área de bolsa periodontal de fumantes e não - fumantes;

4- Correlacionar as condições clínicas com os dados histomorfométricos de fumantes e não - fumantes.

5- Comparar entre fumantes e não-fumantes, o total de dentes perdidos e correlacionar no grupo de fumantes os aspectos de: número de cigarros por dia e tempo de duração do vício. 


\section{Material e Métodos}




\section{Material e Métodos}

Este trabalho foi submetido à apreciação e aprovado pelo Comitê de Ética em Pesquisa da Faculdade de Odontologia de Bauru, Universidade de São Paulo, sob o n019/2002/FOB. Os pacientes foram instruídos quanto à natureza da pesquisa e, após darem seu Consentimento Livre e Esclarecido, foram selecionados para o estudo.

\subsection{SELEÇÃO DA AMOSTRA}

Os candidatos à pesquisa foram encaminhados por CirurgiõesDentistas, Universidade do Oeste do Paraná (UNIOESTE), ABO-Cascavel e por matéria divulgada em jornal e televisão.

Os critérios para seleção dos pacientes foram os seguintes:

> não-fumantes e fumantes entre 30 e 50 anos de idade na época da seleção, sem distinção de raça e/ou sexo.

$>$ fumantes de aproximadamente 1 carteira ou mais de cigarros/dia.

$>$ residentes em Cascavel-PR, pela facilidade de atendimento em consultório particular neste município.

ausência de alterações sistêmicas ou periodontais agudas que pudessem interferir nos resultados.

não ter se submetido a tratamento periodontal nos últimos 6 meses, a fim de evitar alterações nos resultados das análises.

não ter feito uso de antibioticoterapia nos últimos 8 meses. 
$>$ presença de pelo menos uma região com bolsa periodontal em dente posterior de $5 \mathrm{~mm}$ ou mais (Periodontite Crônica).

Três profissionais previamente calibrados, sendo uma aluna do Mestrado Interinstitucional em Odontologia, disciplina de Periodontia e dois cirurgiões-dentistas realizaram anamnese e sondagem preliminar em dentes posteriores de 160 indivíduos, com sonda periodontal tipo Michigan (HuFriedy P-15), para a confirmação dos critérios de seleção.

\subsection{PALESTRA}

Dos 160 indivíduos examinados, 30 fumantes e 30 nãofumantes que preencheram os requisitos da seleção; foram selecionados e convidados a participar de palestra sobre doença periodontal, tabaco como fator de risco na cavidade bucal e explicação sobre o Projeto de pesquisa. Nesta fase, os indivíduos não receberam qualquer informação sobre higiene e fisioterapia oral a fim de não comprometer a coleta de dados clínicos.

\subsection{REGISTRO DAS CONDIÇÕES PERIODONTAIS}

Após a palestra, os indivíduos foram agendados para uma consulta em consultório particular com objetivo de exame periodontal minucioso, que foi realizado unicamente pela aluna autora do projeto. A avaliação foi feita em todos os dentes presentes. Os parâmetros clínicos avaliados foram os seguintes:

$>$ Profundidade de sondagem(PS);

> Índice gengival-IG (LÖE $\left.{ }^{70}, 1967\right)$;

> Índice de sangramento gengival-ISG (AINAMO; BAY $\left.{ }^{3}, 1975\right)$; 
> Índice de placa-IP (SILNESS \& LÖE $\left.{ }^{105}, 1964\right) ;$

Nível de inserção clínica(NI) e recessão gengival(R).

Todos os parâmetros foram obtidos em sessão única e anotados em ficha clínica, especialmente formulada para a ocasião. Do total de indivíduos examinados, permaneceram na pesquisa 55, sendo 29 fumantes e 26 não-fumantes.

\subsubsection{Profundidade de sondagem}

A profundidade de sondagem correspondeu à distância da margem gengival ao ponto mais apical do fundo do sulco/bolsa. Esta tomada foi realizada com sonda periodontal manual milimetrada (marcação de Willians), tipo Michigan (HU-FRIEDY P15) com leve pressão (aproximadamente 25g) o mais paralelo possível do longo eixo do dente, em 6 sítios de cada dente (distovestibular, centro da face vestibular, mesiovestibular, distolingual, centro da face lingual e mesiolingual).

Como regra geral, na leitura da sonda, quando não houve coincidência com as marcas milimetradas, arredondou-se para mais até o próximo milímetro.

\subsection{2 Índice gengival- IG (LÖE $\left.{ }^{70}, 1967\right)$}

Baseou-se no sangramento à exploração do sulco gengival, após a realização da medida da profundidade de sondagem clínica pela inserção e deslizamento da sonda periodontal ao longo da parede mole do sulco gengival e/ou bolsa e em áreas com sinais visíveis de inflamação da 
margem gengival (mudança de cor, edema, brilho...),estabelecendo escores de 0 a 3 . Os tecidos ao redor de cada dente foram divididos em quatro unidades gengivais mensuráveis: papila distovestibular, margem vestibular, papila mesiovestibular e toda a margem lingual. Para minimizar a variabilidade do exame na avaliação, a superfície lingual não foi subdividida, uma vez que foi vista indiretamente com espelho bucal. Os critérios de avaliação foram:

Grau 0: gengiva clinicamente saudável.

Grau 1: inflamação leve: gengiva com ligeira alteração na cor, pouco edema, sem sangramento à sondagem.

Grau 2: inflamação moderada: gengiva edemaceada, brilhante, avermelhada ou azulada, e com sangramento à sondagem.

Grau 3: inflamação severa: gengiva com rubor intenso, edema marcante, ulcerações da margem e tendência ao sangramento espontâneo.

\subsection{3 Índice de placa - IP ( SILNESS \& LÖE ${ }^{105}, 1967$ )}

As avaliações foram feitas nos mesmos locais que o IG: as superfícies proximais (distais, mesiais) e livres (vestibulares e linguais) foram avaliadas para cada dente selecionado. Os critérios para avaliação foram os seguintes:

Grau 0: Sem placa na região gengival.

Grau 1: Sem placa visível a olho nu, mas visível na extremidade da sonda, após movê-la pela superfície 
na entrada do sulco gengival.

Grau 2: Acúmulo moderado de resíduos moles dentro da bolsa gengival, na margem gengival e/ou na superfície adjacente do dente e que pôde ser visível a olho nu.

Grau 3: Abundância de matéria mole dentro da bolsa gengival e/ou na margem gengival e na superfície adjacente do dente.

\subsection{4. Índice de sangramento gengival- ISG (AINAMO; $B A Y,{ }^{3}$ 1975).}

O ISG referiu-se à presença ou ausência de sangramento após delicada sondagem do sulco gengival com sonda periodontal, mesmo sem características clínicas visíveis de alterações marginais. Quando ocorreu sangramento em até 10 segundos após a sondagem, considerou-se ISG positivo. O número de achados positivos foi expresso como uma percentagem do número de margens gengivais examinadas.

\subsubsection{Nível de Inserção Clínica / Recessão Gengival}

O nível de inserção clínica foi avaliado com a mesma sonda HU-FRIEDY P15 e traduzido como a distância em milímetros da junção cemento-esmalte até o fundo do sulco gengival ou da bolsa nos 6 sítios correspondentes à sondagem.

A recessão gengival correspondeu à distância da margem gengival até a junção cemento-esmalte. 


\subsection{PROCEDIMENTO DE BIÓPSIA}

Dos 55 pacientes examinados, 5 não-fumantes e 5 fumantes foram selecionados para a realização de biópsia em área de bolsa periodontal posterior, com maiores índices gengivais e indicação cirúrgica. Nenhum procedimento prévio de preparo básico e/ou de higiene fisioterapia foi realizado. O acesso ao sítio em questão foi feito pela técnica de bisel inverso com lâmina de bisturi 15 e recolhido por leve descolamento de apical para coronal. O fragmento gengival da parede mole da bolsa, que seria naturalmente descartado, foi aproveitado como biópsia para o exame histológico.

\subsubsection{Processamento histológico}

As peças biopsiadas foram mantidas em formol a $10 \%$ em tampão fosfato por uma semana. Todo o material foi processado no Departamento de Ciências Biológicas/ Histologia da FOB-USP, conforme a seqüência abaixo:

a) lavagem em água destilada por 24 horas;

b) banho em etanol $70 \%$ até o dia seguinte;

c) banho de uma hora em etanol a $80 \%$;

d) banho de uma hora em etanol a 90\%;

e) banho de uma hora em etanol a 95\%;

f) dois banhos de uma hora cada em etanol a 100\%;

g) banho de etanol a $100 \%$ durante 24 horas;

h) banho de trinta minutos em xilol;

i) banho de uma hora em xilol; 
j) banho em Histosec (parafina + resina) por uma hora;

k) banho em Histosec por 8 horas;

I) inclusão em Histosec realizada de maneira que a peça pudesse ser cortada, apresentando de um lado o epitélio juncional e ou seu espaço e do outro, o epitélio oral.

m) cortes semi-seriados de $5 \mu \mathrm{m}$ de espessura obtidos em um micrótomo Jung Leica e corados pela técnica da hematoxilina-eosina.

\subsubsection{Determinações morfométricas}

\subsubsection{Casualização dos campos microscópicos}

Todos os métodos estereológicos são baseados em princípiosgeométrico-estatísticos, derivados da probabilidade em que imagens da estrutura na secção histológica coincidam com um sistema-teste apropriado. Deste modo, o ponto central nesses métodos está na casualização das amostras, ou seja, a escolha das amostras do tecido a serem confrontadas com o sistema-teste, deve ser realizada por um método que elimine a ocorrência de vício na amostragem. Isto é conseguido pela aplicação de procedimento de casualização em todos os estágios do experimento, desde a escolha dos participantes, a seleção dos blocos histológicos em cada lâmina e principalmente a seleção dos campos microscópicos a serem utilizados nas quantificações.

De cada biópsia foram obtidas 10 lâminas contendo 6 cortes semi-seriados cada uma. Através de sorteio foram escolhidas 5 lâminas para serem utilizadas e de cada lâmina selecionado um (1) corte histológico. 
Para a escolha dos 10 campos microscópicos por corte, utilizou-se um esquema de casualização sistemática segundo as indicações de WEIBEL ${ }^{114}$ (1969). Saliente-se que nesse esquema os campos microscópicos foram escolhidos em intervalos regulares, de maneira que todas as regiões do corte histológico fossem representadas. A seleção dos campos iniciou-se no conjuntivo gengival, lateralmente ao epitélio juncional, seguindo em direção ao epitélio oral da gengiva livre, evitando-se o fundo da bolsa, onde o processo inflamatório poderia comprometer os dados.

\subsubsection{Determinação da densidade de volume (\%)}

A densidade de volume de TN(tecido normal) e TI(tecido inflamado) foi determinada em um sistema de análise de imagem digitalizada, composto por um microscópio Zeiss Axioskop 2 com objetiva de imersão 100X, câmera CCD-IRIS RGB - Sony e software Kontron KS300 (Kontron Electronic GMBM), instalado em um computador IBM. Para tanto, foram capturadas 25 imagens por biópsias, selecionadas por amostragem sistemática (WEIBEL $\left.{ }^{114}, 1969\right)$. Para cada imagem obtida, foi sobreposta a imagem do retículo de integração Zeiss II, composto por 10 linhas paralelas e 100 pontos (Fig1) e anotados os pontos que caíram sobre cada tipo de estrutura a ser analisada (i) e sobre a estrutura toda (P). A densidade de volume (d) foi calculada pela seguinte relação $d=i / P$.

\subsubsection{Número total de células}

O número de células de inflamatórias como um todo e de fibroblastos foi determinado pelo método de Aherne II, usando uma objetiva 
de imersão de 100x e um gratículo de integração II Zeiss, colocado em uma ocular Kpl 8X, composta de 10 linhas paralelas e 100 pontos numa área quadrangular. A imagem do gratículo foi superposta sucessivamente a 50 campos histológicos escolhidos por amostragem sistemática (Weibel,1969), e os seguintes dados foram anotados: a) número de intersecções (c) do núcleo com as linhas do gratículo; e b) número de núcleos (ni) de cada estrutura. Conhecendo-se a área total analisada (A), a distância entre as linhas do gratículo (d) e a espessura do corte (t); o número total de núcleos de cada tipo celular foi calculado pela fórmula $\mathrm{Ni}=2 \mathrm{n} / \mathrm{A}[(\mathrm{c} / \mathrm{n}) \cdot \mathrm{d}+2 \mathrm{t}]$.

\subsection{ANÁLISE ESTATÍSTICA}

Foram utilizados o Teste de Comparação "t" de Student e o Coeficiente de Correlação de Pearson para as análises estatísticas. 
5 Resultados 


\section{$5 \quad$ Resultados}

Neste capítulo estão expressos os resultados estatísticos comparativos (Teste "t" de Student) dos dados clínicos e histomorfométricos, a análise histomorfológica bem como o Coeficiente de correlação de Pearson de dados clínicos e histomorfométricos, entre indivíduos fumantes e não-fumantes.

Os parâmetros clínicos abordados foram: profundidade de sondagem(PS), Recessão gengival(R), Nível de Inserção clínica(NI), Índice Gengival(IG), Índice de Sangramento gengival(ISG) e Índice de Placa(IP).

Os dados histomorfométricos foram referentes à densidade de volume (\%) de tecido conjuntivo gengival adjacente à bolsa periodontal, número de células inflamatórias e fibroblastos. 


\subsection{RESULTADOS CLÍNICOS}

Tabela 1: Análise comparativa (Teste " $\mathrm{t}$ " Student) da profundidade de sondagem (PS) por área (anterior e posterior), por face (vestibular, lingual/palatina, proximais) e por arcada (superior e inferior) entre os grupos de fumantes(n.29) e não-fumantes(n.26)

\begin{tabular}{|c|c|c|c|c|c|c|}
\hline \multirow[b]{2}{*}{ Regiões } & \multicolumn{2}{|c|}{ Fumantes } & \multicolumn{2}{|c|}{ Não-fumantes } & \multirow[b]{2}{*}{$\mathbf{t}$} & \multirow[b]{2}{*}{$\mathbf{p}$} \\
\hline & $\bar{x}(\mathrm{~mm})$ & $d p$ & $\bar{x}(\mathrm{~mm})$ & $d p$ & & \\
\hline Ps & 3,36 & 0,81 & 2,97 & 0,69 & 1,862 & 0,068 \\
\hline AS & 3,02 & 0,93 & 2,64 & 0,89 & 1,525 & 0,133 \\
\hline $\mathrm{PI}$ & 2,91 & 0,75 & 2,64 & 0,86 & 1,215 & 0,229 \\
\hline $\mathrm{Al}$ & 2,76 & 0,92 & 2,37 & 0,90 & 1,609 & 0,113 \\
\hline PsFP & 3,75 & 0,97 & 3,35 & 0,82 & 1,611 & 0,113 \\
\hline PsFV & 2,13 & 0,72 & 2,04 & 0,65 & 0,477 & 0,634 \\
\hline PsFL & $3,04^{*}$ & $1,01^{*}$ & $2,36^{*}$ & $0,59^{*}$ & $2,922^{*}$ & $0,005^{*}$ \\
\hline PIFP & 3,14 & 0,81 & 2,89 & 0,97 & 1,052 & 0,297 \\
\hline PIFV & 2,08 & 0,81 & 1,86 & 0,70 & 1,072 & 0,288 \\
\hline PIFL & 2,82 & 0,79 & 2,45 & 0,83 & 1,650 & 0,104 \\
\hline ASFP & 3,37 & 1,11 & 2,98 & 1,03 & 1,347 & 0,183 \\
\hline ASFV & 1,79 & 0,46 & 1,62 & 0,63 & 1,130 & 0,263 \\
\hline ASFL & 2,86 & 1,08 & 2,33 & 0,95 & 1,906 & 0,061 \\
\hline AlFP & 3,12 & 1,06 & 2,69 & 1,04 & 1,518 & 0,134 \\
\hline AIFV & 1,88 & 0,76 & 1,67 & 0,72 & 1,063 & 0,292 \\
\hline$\overline{A I F L}$ & 2,22 & 0,80 & 1,78 & 0,81 & 2,002 & 0,050 \\
\hline
\end{tabular}

Ps: postero-superior AS: antero-superior PI: postero-inferior Al: antero-inferior FP: faces proximais FV: face vestibular FL: face lingual/palatina 


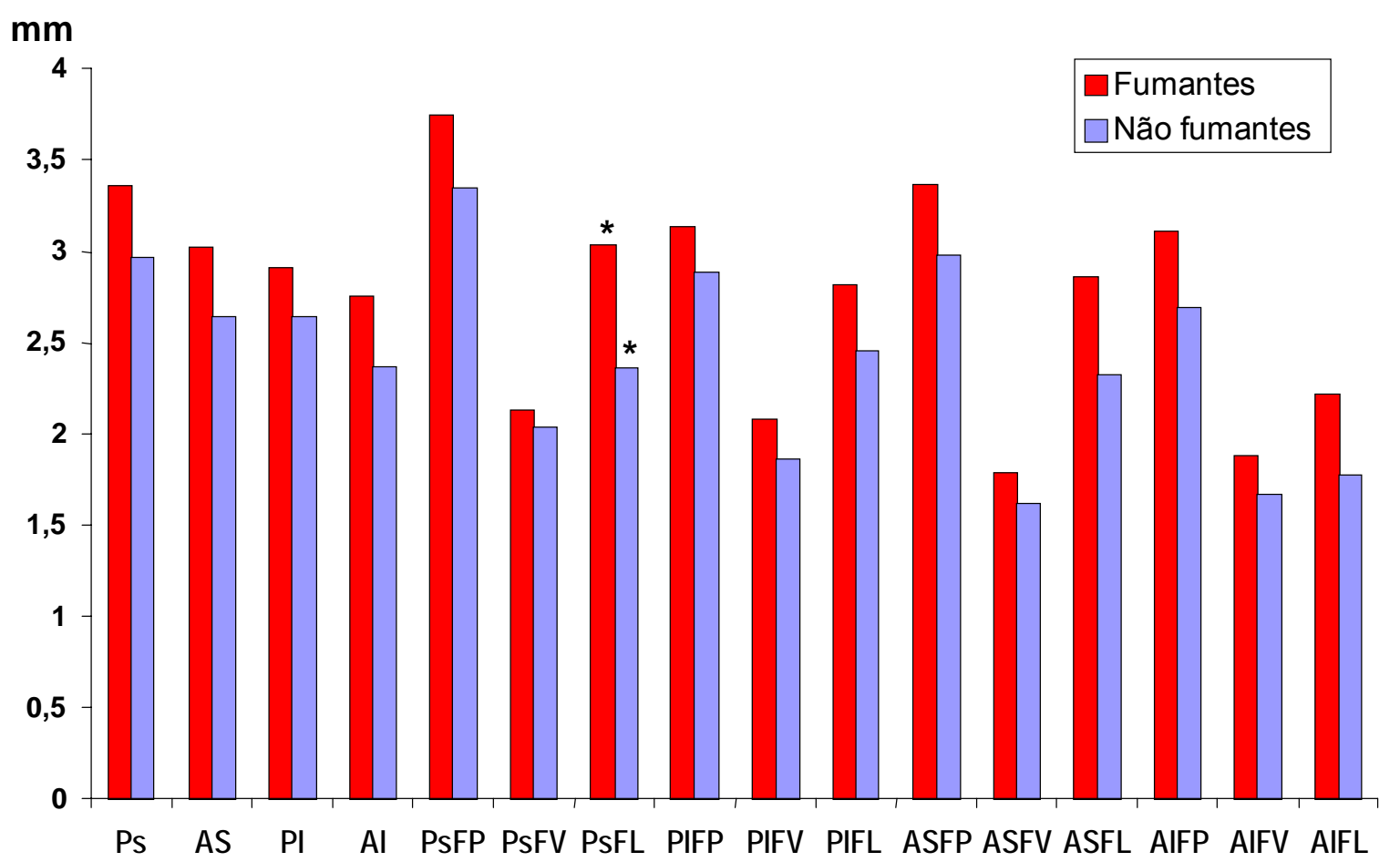

\section{Profundidade de sondagem}

Figura 1: Gráfico da profundidade de sondagem (PS) por área (anterior e posterior), por face (vestibular, lingual/palatina, proximais) e por arcada (superior e inferior) entre os grupos de fumantes $\left(n^{\circ} 29\right)$ e nãofumantes $\left(n^{\circ} 26\right)$

$\mathrm{Na}$ Tabela 1 e Figura 1 onde se fez a análise comparativa entre os grupos de fumantes ( $\left.n^{\circ} 29\right)$ com o grupo de não-fumantes ( $\left.n^{\circ} 26\right)$, quanto à profundidade de sondagem (PS), pôde-se verificar que para todas as situações avaliadas, seja por área, face ou arcada, sempre houve tendência a menores médias de PS para o grupo de não-fumantes, embora apenas nas faces palatinas posteriores essa diferença tenha sido estatisticamente significante $\left(^{*}\right)$. 
Tabela 2: Análise comparativa (Teste "t" Student) da recessão gengival (RG) por área (anterior e posterior), por face (vestibular, lingual/palatina, proximais) e por arcada (superior e inferior) entre os grupos de fumantes (n.29) e não-fumantes (n.26)

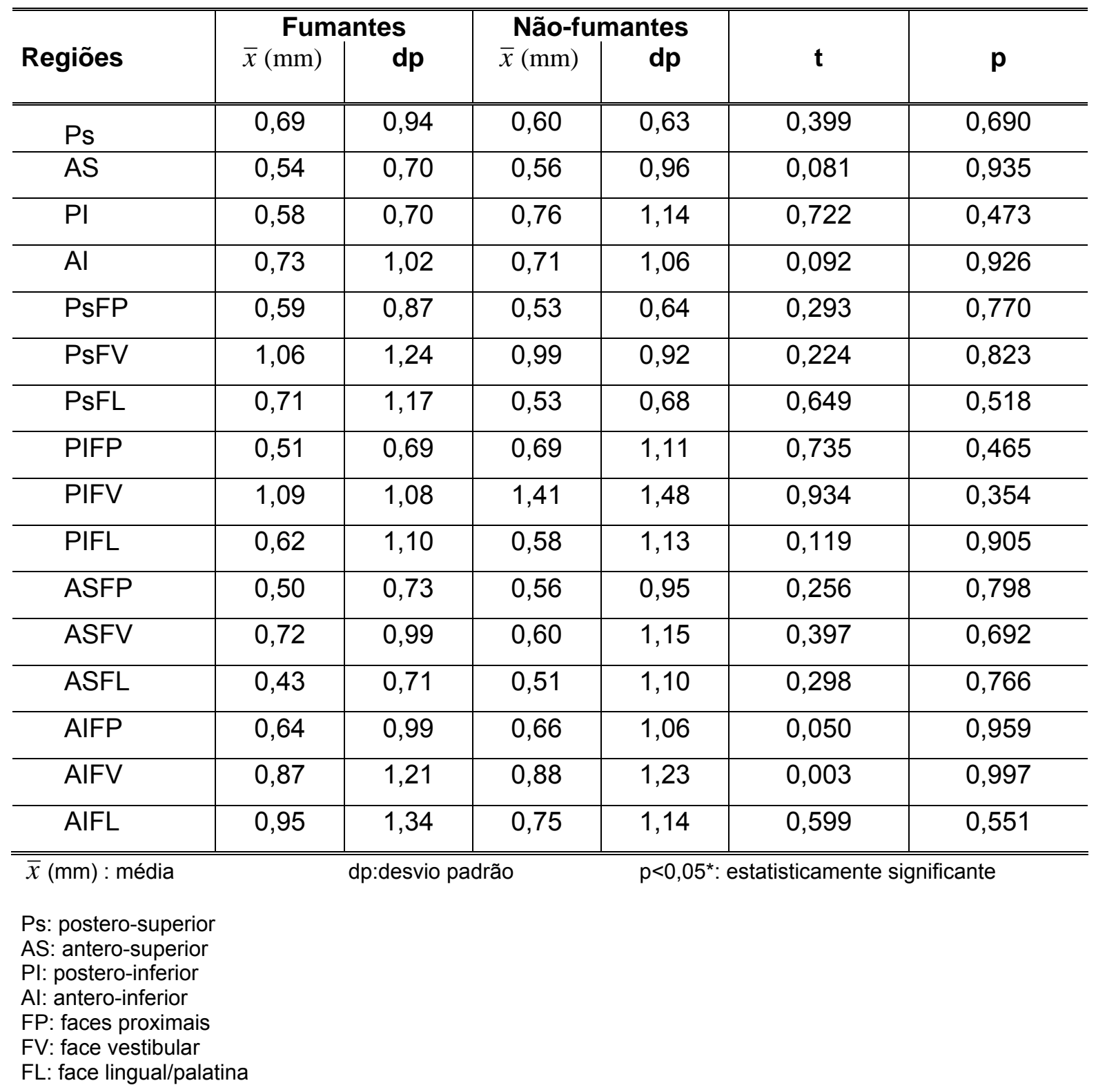




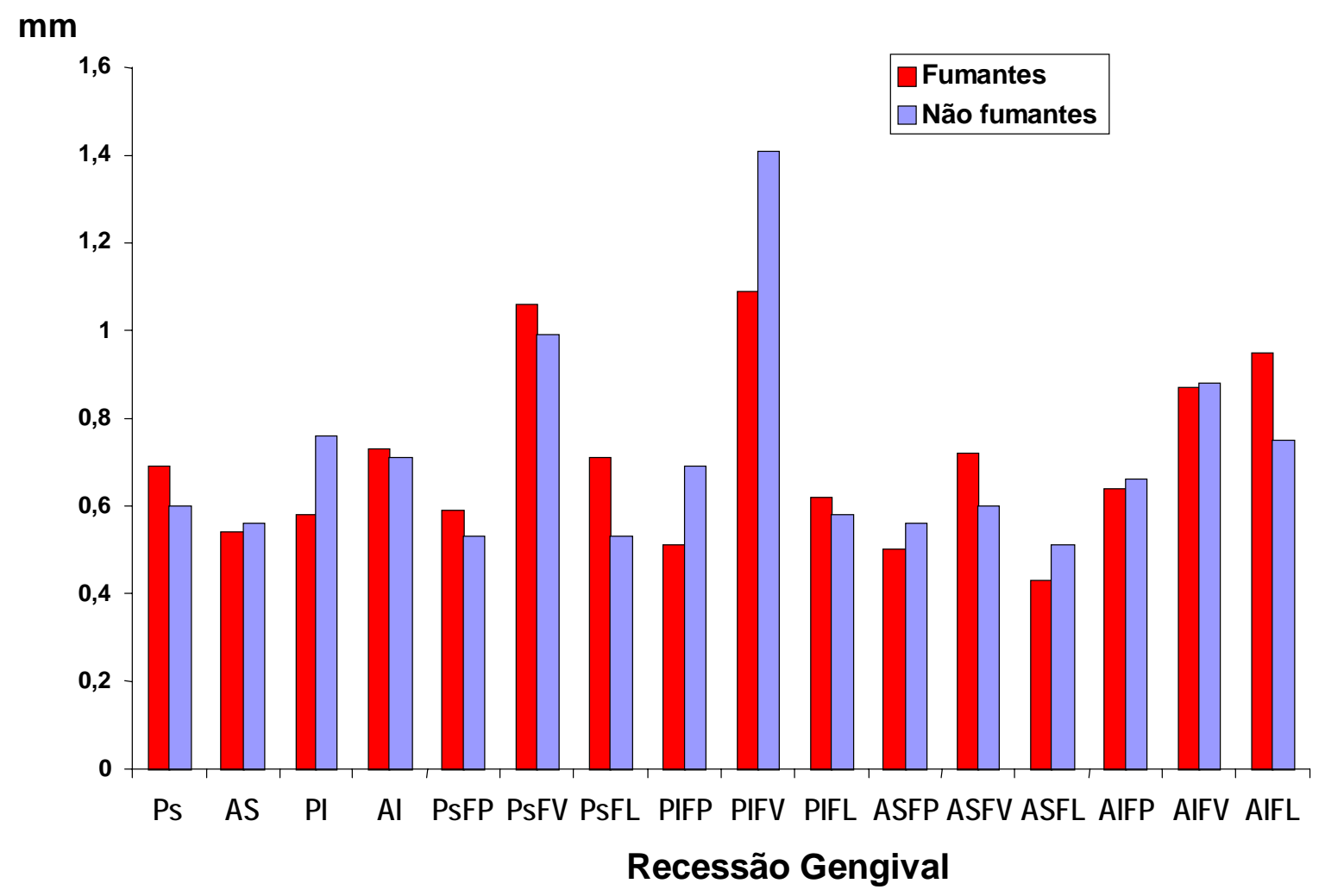

Figura 2: Gráfico da recessão gengival (RG) por área (anterior e posterior), por face (vestibular, lingual/palatina, proximais) e por arcada (superior e inferior) entre os grupos de fumantes $\left(n^{\circ} 29\right)$ e nãofumantes $\left(n^{\circ} 26\right)$

Na Tabela 2 e Figura 2, é apresentada a análise comparativa entre fumantes e não-fumantes, quanto às recessões gengivais(RG), podendo-se constatar que não ocorreu constância de maiores valores para fumantes ou não-fumantes e em nenhuma das situações houve diferenças estatisticamente significantes. 
Tabela 3: Análise comparativa (Teste "t" Student) do nível de inserção clínica (NI) por área (anterior e posterior), por face (vestibular, lingual/palatina, proximais) e por arcada (superior e inferior) entre os grupos de fumantes $\left(n^{\circ} 29\right)$ e não-fumantes $\left(n^{\circ} 26\right)$

\begin{tabular}{l|c|c|c|c|c|c}
\hline \multirow{2}{*}{ Regiões } & \multicolumn{2}{|c|}{ Fumantes } & \multicolumn{2}{c|}{ Não-fumantes } & \multirow{2}{*}{ t } & $\mathbf{p}$ \\
\hline \hline Ps & $\bar{x}(\mathrm{~mm})$ & $\mathbf{d p}$ & $\bar{x}(\mathrm{~mm})$ & $\mathbf{d p}$ & & \\
\hline AS & 4,01 & 1,45 & 3,51 & 0,99 & 1,433 & 0,157 \\
\hline PI & 3,55 & 1,44 & 3,20 & 1,61 & 0,846 & 0,401 \\
\hline AI & 3,48 & 1,11 & 3,41 & 1,68 & 0,171 & 0,864 \\
\hline PsFP & 3,50 & 1,53 & 3,07 & 1,81 & 0,941 & 0,350 \\
\hline PsFV & 4,30 & 1,51 & 3,82 & 1,08 & 1,308 & 0,196 \\
\hline PsFL & 3,13 & 1,51 & 3,02 & 1,22 & 0,309 & 0,757 \\
\hline PIFP & $3,71^{*}$ & $1,75^{*}$ & $2,81^{*}$ & $0,94^{*}$ & $2,297^{*}$ & $0,025^{*}$ \\
\hline PIFV & 3,17 & 1,13 & 3,54 & 1,76 & 0,162 & 0,871 \\
\hline PIFL & 3,33 & 1,48 & 3,05 & 1,63 & 0,680 & 0,499 \\
\hline ASFP & 3,86 & 1,62 & 3,53 & 1,72 & 0,728 & 0,469 \\
\hline ASFV & 2,50 & 1,15 & 2,23 & 1,35 & 0,807 & 0,423 \\
\hline ASFL & 3,29 & 1,60 & 2,85 & 1,81 & 0,970 & 0,336 \\
\hline AIFP & 3,76 & 1,67 & 3,34 & 1,95 & 0,865 & 0,390 \\
\hline AIFV & 2,75 & 1,42 & 2,51 & 1,44 & 0,613 & 0,542 \\
\hline AIFL & 3,18 & 1,51 & 2,58 & 1,83 & 1,330 & 0,189 \\
\hline \hline
\end{tabular}

Ps: postero-superior

AS: antero-superior

PI: postero-inferior

$\mathrm{Al}$ : antero-inferior

FP: faces proximais

FV: face vestibular

FL: face lingual/palatina 


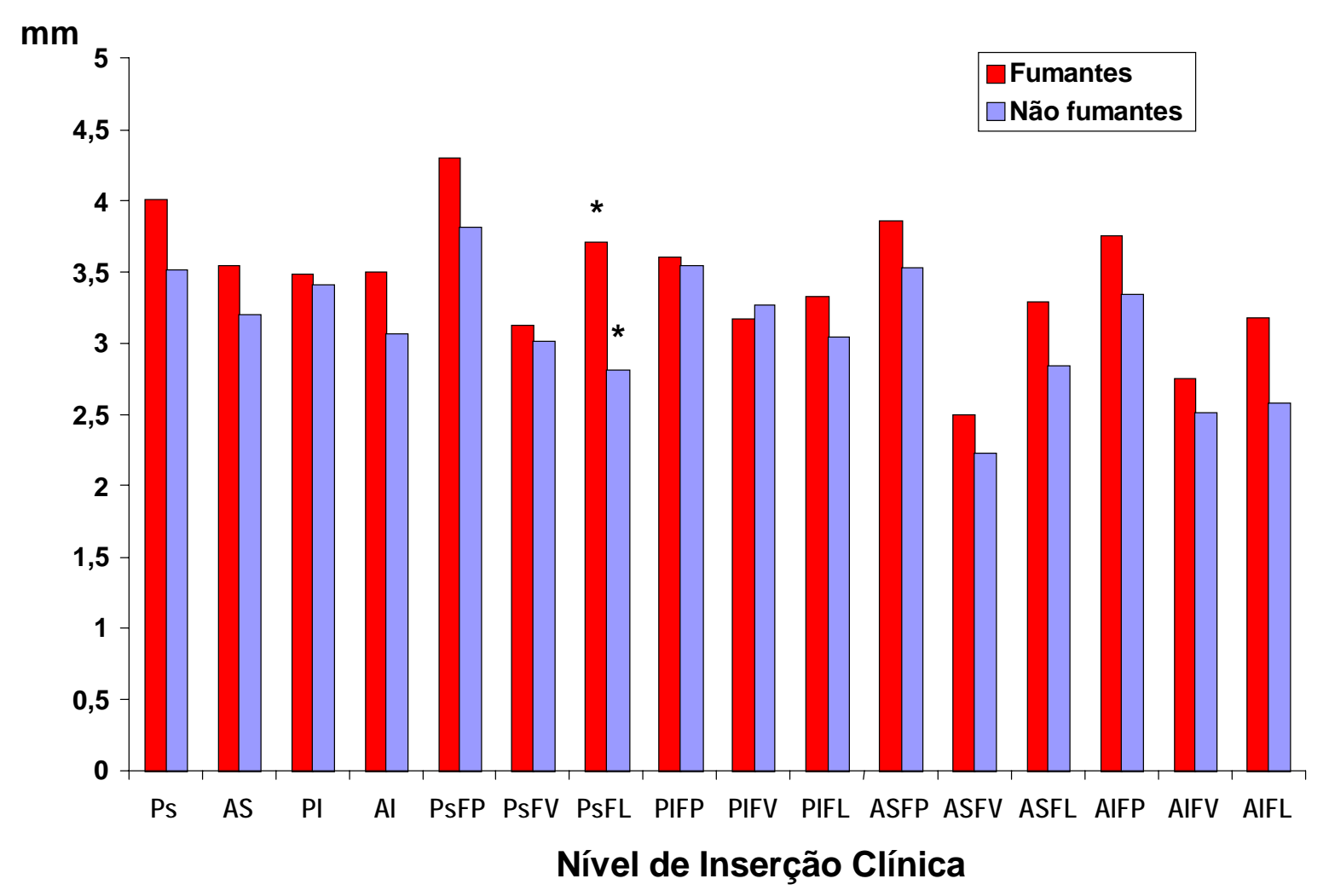

Figura 3: Gráfico do nível de inserção clínica (NI) por área (anterior e posterior), por face (vestibular, lingual/palatina, proximais) e por arcada (superior e inferior) entre os grupos de fumantes $\left(n^{\circ} 29\right)$ e não-fumantes $\left(n^{\circ} 26\right)$

Quando da análise do nível de inserção clínica(Tabela 3 e

Figura 3), dentre as múltiplas situações avaliadas, pôde-se verificar uma situação muito semelhante à profundidade de sondagem(PS), ocorrendo valores sempre maiores no grupo de fumantes, exceto para as faces vestibulares posteriores inferiores. Entretanto, semelhante à PS, ocorreu significância estatística apenas nas faces palatinas posteriores superiores, com média maior para o grupo de fumantes. 
Tabela 4: Análise comparativa (Teste "t" Student) do índice gengival(IG) por área (anterior e posterior), por face (vestibular, lingual/palatina, proximais) e por arcada (superior e inferior) entre os grupos de fumantes $\left(n^{\circ} 29\right)$ e não-fumantes $\left(n^{\circ} 26\right)$

\begin{tabular}{|c|c|c|c|c|c|c|}
\hline \multirow[b]{2}{*}{ Regiões } & \multicolumn{2}{|c|}{ Fumantes } & \multicolumn{2}{|c|}{ Não-fumantes } & \multirow[b]{2}{*}{$\mathbf{T}$} & \multirow[b]{2}{*}{$\mathbf{p}$} \\
\hline & $\bar{x}$ & dp & $\bar{x}$ & dp & & \\
\hline Ps & $0,57^{*}$ & $0,59^{*}$ & $1,19^{*}$ & $0,67^{*}$ & $3,639^{*}$ & $0,000^{*}$ \\
\hline AS & $0,48^{*}$ & $0,63^{*}$ & $1,17^{*}$ & $0,65^{*}$ & $3,908^{*}$ & $0,000^{*}$ \\
\hline $\mathrm{PI}$ & $0,61^{*}$ & $0,61^{*}$ & $1,12^{*}$ & $0,80^{*}$ & $2,655^{*}$ & $0,104^{*}$ \\
\hline $\mathrm{Al}$ & $0,63^{*}$ & $0,73^{*}$ & $1,04^{*}$ & $0,70^{*}$ & $2,096^{*}$ & $0,407^{*}$ \\
\hline PsFP & $0,59^{*}$ & $0,61^{*}$ & $1,20^{*}$ & $0,75^{*}$ & $3,278^{*}$ & $0,001^{*}$ \\
\hline PsFV & $0,51^{*}$ & $0,57^{*}$ & $1,16^{*}$ & $1,21^{*}$ & $2,580^{*}$ & $0,127^{*}$ \\
\hline PsFL & $0,58^{*}$ & $0,68^{*}$ & $1,46^{*}$ & $0,78^{*}$ & $4,435^{*}$ & $0,000^{*}$ \\
\hline PIFP & 0,57 & 0,63 & 0,92 & 0,68 & 1,968 & 0,542 \\
\hline PIFV & 0,52 & 0,59 & 0,77 & 0,66 & 1,506 & 0,137 \\
\hline PIFL & $0,80^{*}$ & $0,83^{*}$ & $1,40^{*}$ & $0,61^{*}$ & $3,003^{*}$ & $0,004^{*}$ \\
\hline ASFP & $0,48^{*}$ & $0,65^{*}$ & $1,41^{*}$ & $0,88^{*}$ & $4,458^{*}$ & $0,000^{*}$ \\
\hline ASFV & $0,34^{*}$ & $0,54^{*}$ & $0,99^{*}$ & $0,81^{*}$ & $3,504^{*}$ & $0,000^{*}$ \\
\hline ASFL & $0,61^{*}$ & $0,84^{*}$ & $1,47^{*}$ & $0,86^{*}$ & $3,721^{*}$ & $0,000^{*}$ \\
\hline AIFP & 0,65 & 0,78 & 0,95 & 0,79 & 1,453 & 0,151 \\
\hline AIFV & 0,57 & 0,74 & 0,82 & 0,81 & 1,209 & 0,231 \\
\hline AIFL & $0,67^{*}$ & $0,82^{*}$ & $1,16^{*}$ & $0,72^{*}$ & $2,354^{*}$ & $0,222^{*}$ \\
\hline
\end{tabular}

$\bar{X}$ : média em escore de 1 a 3

Ps: postero-superior

AS: antero-superior

PI: postero-inferior

Al: antero-inferior

FP: faces proximais

FV: face vestibular

FL: face lingual/palatina 


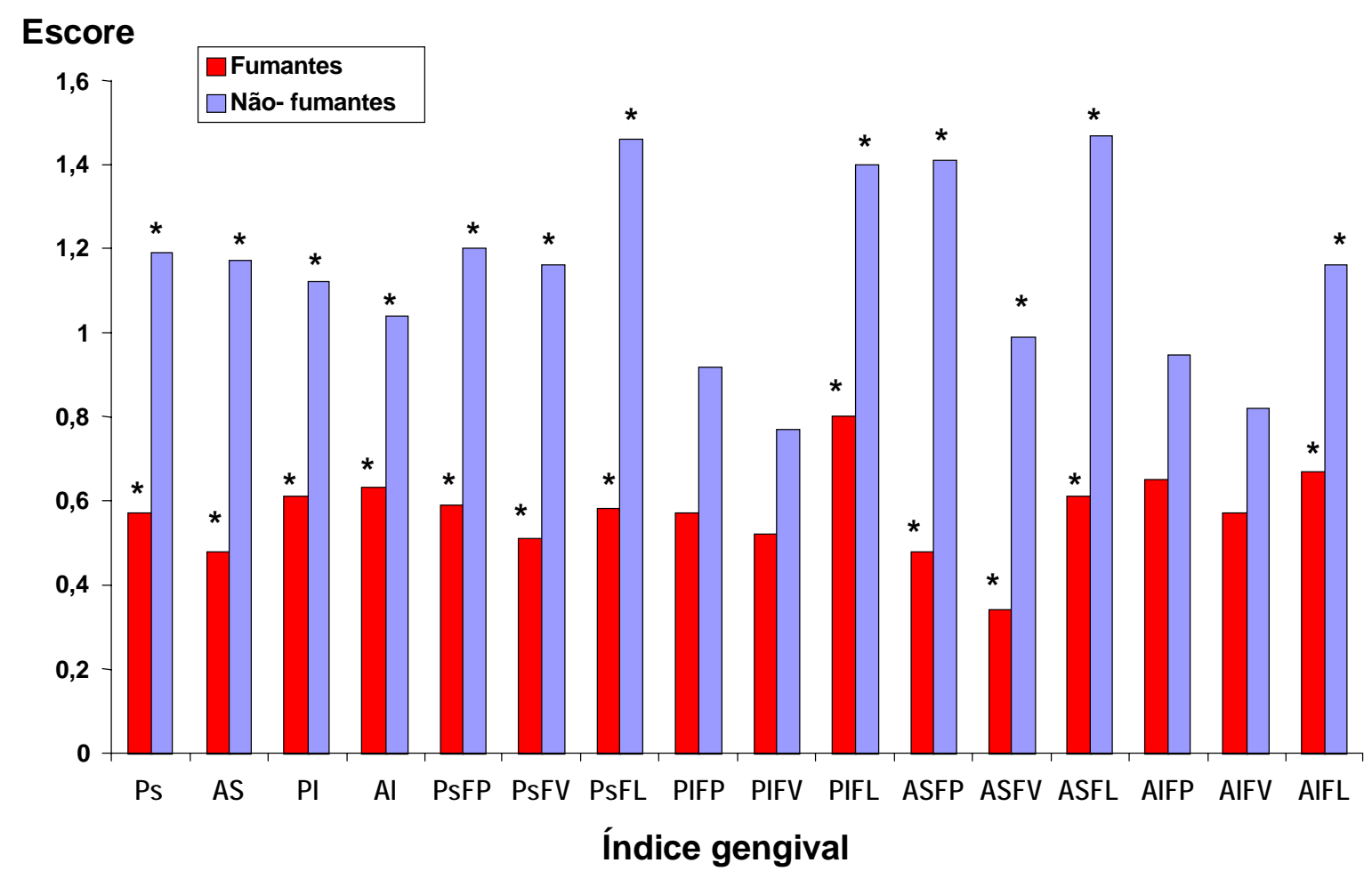

Figura 4: Gráfico do índice gengival(IG) por área (anterior e posterior), por face (vestibular, lingual/palatina, proximais) e por arcada (superior e inferior) entre os grupos de fumantes $\left(n^{\circ} 29\right)$ e não-fumantes $\left(n^{\circ} 26\right)$

Comparando o índice gengival (IG) nas situações analisadas (Tabela 4 e Figura 4), pôde-se verificar que em todas elas, os valores foram maiores para o grupo de não-fumantes, tendo havido significância estatística para a grande maioria das regiões.

Quando se avaliou por face, houve significância para todas as faces (proximais, vestibulares e palatinas) dos dentes superiores, tanto nos posteriores, quanto nos anteriores. Nos dentes inferiores, houve significância nas faces linguais de posteriores e anteriores, não havendo significância para as faces proximais e vestibulares de dentes inferiores. 
Tabela 5: Análise comparativa (Teste "t" Student) do índice de sangramento gengival(ISG) por área (anterior e posterior), por face (vestibular, lingual/palatina, proximais) e por arcada (superior e inferior) entre os grupos de fumantes $\left(n^{\circ} 29\right)$ e não-fumantes $\left(n^{\circ} 26\right)$

\begin{tabular}{|c|c|c|c|c|c|c|}
\hline \multirow[b]{2}{*}{ Regiões } & \multicolumn{2}{|c|}{ Fumantes } & \multicolumn{2}{|c|}{ Não-fumantes } & \multirow[b]{2}{*}{$\mathbf{T}$} & \multirow[b]{2}{*}{$\mathbf{p}$} \\
\hline & $\bar{x}$ & dp & $\bar{X}$ & $d p$ & & \\
\hline Ps & 0,60 & 0,25 & 0,63 & 0,22 & 0,419 & 0,676 \\
\hline AS & 0,46 & 0,27 & 0,58 & 0,24 & 1,614 & 0,112 \\
\hline $\mathrm{PI}$ & 0,53 & 0,25 & 0,53 & 0,29 & 0,595 & 0,952 \\
\hline $\mathrm{Al}$ & 0,48 & 0,29 & 0,57 & 0,31 & 1,112 & 0,270 \\
\hline PsFP & 0,60 & 0,31 & 0,60 & 0,24 & 0,067 & 0,946 \\
\hline PsFV & 0,44 & 0,30 & 0,46 & 0,29 & 0,243 & 0,808 \\
\hline PsFL & 0,75 & 0,29 & 0,83 & 0,19 & 1,080 & 0,285 \\
\hline PIFP & 0,50 & 0,28 & 0,46 & 0,33 & 0,488 & 0,627 \\
\hline PIFV & 0,58 & 0,90 & 0,42 & 0,38 & 0,806 & 0,423 \\
\hline PIFL & 0,70 & 0,34 & 0,76 & 0,29 & 0,647 & 0,519 \\
\hline ASFP & 0,46 & 0,31 & 0,62 & 0,31 & 1,891 & 0,064 \\
\hline ASFV & 0,25 & 0,31 & 0,31 & 0,31 & 0,670 & 0,505 \\
\hline ASFL & 0,68 & 0,36 & 0,75 & 0,25 & 0,788 & 0,433 \\
\hline AIFP & 0,47 & 0,32 & 0,56 & 0,35 & 0,994 & 0,324 \\
\hline AIFV & 0,36 & 0,32 & 0,43 & 0,39 & 0,759 & 0,451 \\
\hline AIFL & 0,62 & 0,34 & 0,69 & 0,30 & 0,895 & 0,374 \\
\hline
\end{tabular}

$\begin{array}{ll}\bar{X} & \text { : média em escore de } 0 \text { a } 1 \quad \text { dp:desvio padrão }\end{array}$

$p<0,05^{\star}$ : estatisticamente significante

Ps: postero-superior

AS: antero-superior

PI: postero-inferior

Al: antero-inferior

FP: faces proximais

FV: face vestibular

FL: face lingual/palatina 


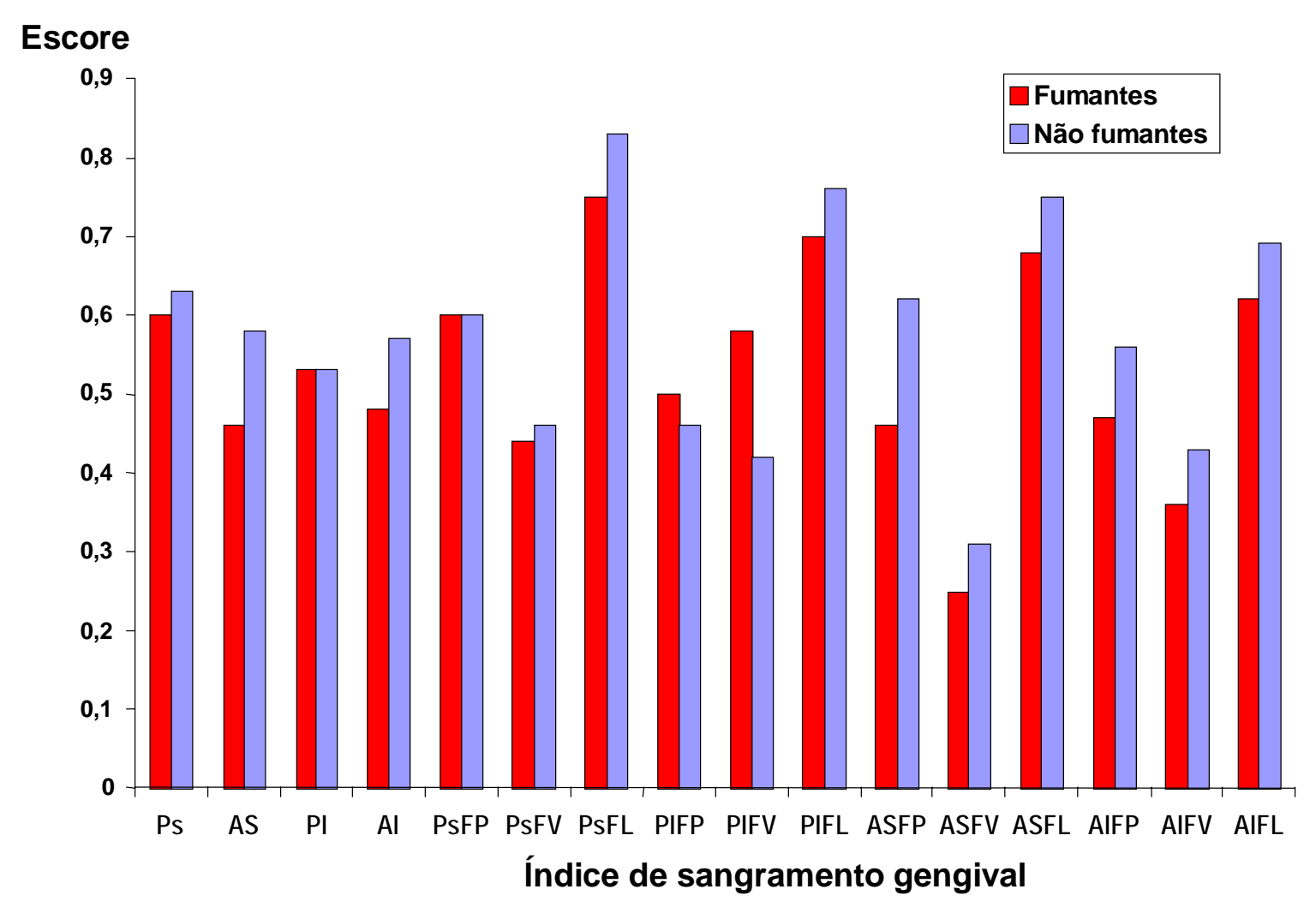

Figura 5: Gráfico do índice de sangramento gengival (ISG) por área (anterior e posterior), por face (vestibular, lingual/palatina, proximais) e por arcada (superior e inferior) entre os grupos de fumantes $\left(n^{\circ} 29\right)$ e nãofumantes $\left(n^{\circ} 26\right)$

Analisando-se o Índice de sangramento gengival (ISG), verifica-se na Tabela 5 e Gráfico 5 que, embora não tenham ocorrido diferenças estatisticamente significantes entre os grupos de fumantes e nãofumantes, houve uma tendência geral a maiores valores, quase sempre, para os não-fumantes. 
Tabela 6: Análise comparativa (Teste " $\mathrm{t}$ " Student) do índice de placa (IP) por área (anterior e posterior), por face (mesial, centro da vestibular,distal, lingual/palatina) e por arcada (superior e inferior) entre os grupos de fumantes $\left(n^{\circ} 29\right)$ e não-fumantes $\left(n^{\circ} 26\right)$

\begin{tabular}{|c|c|c|c|c|c|c|}
\hline \multirow[b]{2}{*}{ Regiões } & \multicolumn{2}{|c|}{ Fumantes } & \multicolumn{2}{|c|}{ Não-fumantes } & \multirow[b]{2}{*}{$\mathbf{T}$} & \multirow[b]{2}{*}{$\mathbf{p}$} \\
\hline & $\bar{x}$ & Dp & $\bar{x}$ & dp & & \\
\hline Ps & 1,49 & 0,72 & 1,22 & 0,61 & 1,449 & 0,153 \\
\hline AS & 1,04 & 0,61 & 0,88 & 0,63 & 0,947 & 0,347 \\
\hline $\mathrm{PI}$ & 1,46 & 0,57 & 1,21 & 0,70 & 1,459 & 0,150 \\
\hline $\mathrm{Al}$ & 1,45 & 0,79 & 1,02 & 0,82 & 1,997 & 0,509 \\
\hline PsFM & 1,41 & 0,81 & 1,14 & 0,60 & 1,375 & 0,174 \\
\hline PsFV & 1,43 & 0,78 & 1,12 & 0,62 & 1,601 & 0,115 \\
\hline PsFD & 1,39 & 0,83 & 1,24 & 0,58 & 0,776 & 0,440 \\
\hline PsFL & 1,68 & 0,83 & 1,39 & 0,82 & 1,314 & 0,194 \\
\hline PIFM & 1,20 & 0,64 & 1,00 & 0,71 & 1,092 & 0,279 \\
\hline PIFV & 1,19 & 0,62 & 0,94 & 0,72 & 1,374 & 0,175 \\
\hline PIFD & 1,26 & 0,63 & 1,16 & 0,71 & 0,567 & 0,573 \\
\hline PIFL & $2,18^{*}$ & $0,65^{*}$ & $1,72^{*}$ & $0,89^{*}$ & $2,180^{*}$ & $0,033^{*}$ \\
\hline ASFM & 0,92 & 0,64 & 0,82 & 0,63 & 0,571 & 0,570 \\
\hline ASFV & 0,92 & 0,62 & 0,81 & 0,65 & 0,631 & 0,530 \\
\hline ASFD & 0,93 & 0,63 & 0,83 & 0,70 & 0,569 & 0,571 \\
\hline ASFL & 1,38 & 0,83 & 1,06 & 0,72 & 1,540 & 0,129 \\
\hline AIFM & 1,26 & 0,83 & 0,92 & 0,83 & 1,497 & 0,140 \\
\hline AIFV & 1,25 & 0,84 & 0,84 & 0,83 & 1,801 & 0,077 \\
\hline AIFD & 1,28 & 0,78 & 0,93 & 0,93 & 1,480 & 0,144 \\
\hline AIFL & $2,21^{*}$ & $0,72^{*}$ & $1,38^{*}$ & $0,89^{*}$ & $3,807^{*}$ & $0,000^{*}$ \\
\hline
\end{tabular}




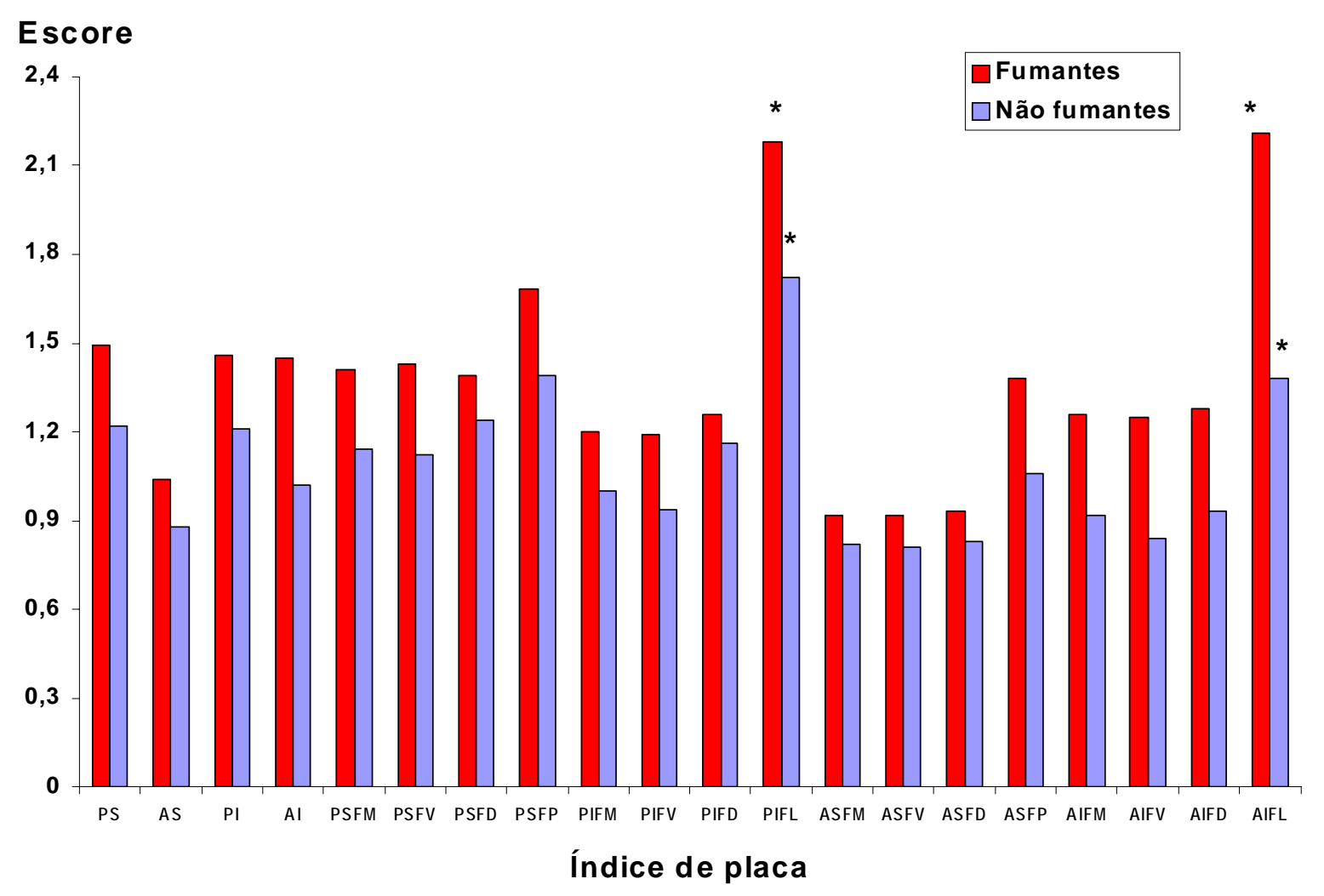

Figura 6: Gráfico do índice de placa (IP) por área (anterior e posterior), por face (mesial, centro da vestibular, distal, lingual/palatina) e por arcada (superior e inferior) entre os grupos de fumantes $\left(n^{\circ} 29\right)$ e não-fumantes $\left(n^{\circ} 26\right)$

Quanto à média do índice de placa (IP) entre os grupos fumantes e não-fumantes, em todas as situações analisadas (tabela 6 e gráfico 6), pôde-se sempre verificar uma constância de maior acúmulo de placa para o grupo de fumantes; entretanto, pôde-se constatar significância estatística apenas nas faces linguais de dentes inferiores, posteriores e anteriores. 


\subsection{RESULTADOS MORFOLÓGICOS}

\section{a) Pacientes fumantes}

A análise histológica da gengiva marginal dos pacientes fumantes mostrou dois quadros bem distintos.

O primeiro quadro, com características próximas da normalidade, apresentou vertente externa, revestida pelo epitélio característico da região, ou seja, escamoso, estratificado, ceratinizado, constituído por células firmemente unidas umas às outras e arranjadas em camadas ou estratos distintos (Figura 7). As papilas na sua grande maioria mostraram-se alinhadas, enfileiradas perpendiculares à superfície do epitélio oral (Figura 7). O tecido conjuntivo da camada papilar superficial mostrou-se constituído por fibras colágenas finas e frouxamente arranjadas, numerosos fibroblastos e pequenos vasos, e o da camada reticular por fibras colágenas arranjadas em feixes espessos, menor número de fibroblastos e vasos homogeneamente distribuídos (Figuras 8 e 9). Ao redor de alguns feixes vasculares, ocorreu presença de macrófagos e células inflamatórias, principalmente linfócitos (Figura 9). O sulco apresentou-se revestido por epitélio estratificado, pavimentoso, não ceratinizado, com moderada hiperplasia, levando a um substancial aumento da sua espessura (Figuras 7 e 8). O tecido conjuntivo próximo ao epitélio juncional exibiu intenso infiltrado inflamatório de característica linfoplasmocitária, com predominância de linfócitos, desde a faixa limitante do sulco e por e toda a extensão da bolsa (Figura 10), caminhando em menor intensidade pelo interior da lâmina própria até as proximidades do limite da vertente externa. 
O segundo quadro histológico, devido ao processo inflamatório mais intenso próximo à bolsa, exibiu hiperplasia do epitélio sulcular com formação de projeções papilares em forma de espículas e fragmentação do epitélio juncional, ver Figuras 11 e 12. A lâmina própria da vertente dentária, próxima ao epitélio, exibiu intenso infiltrado inflamatório linfoplasmocitário, com presença de neutrófilos, degradação das fibras colágenas e intensa hiperemia vascular com extravasamento de leucócitos para o conjuntivo subjacente (Figuras 13 e 14). 


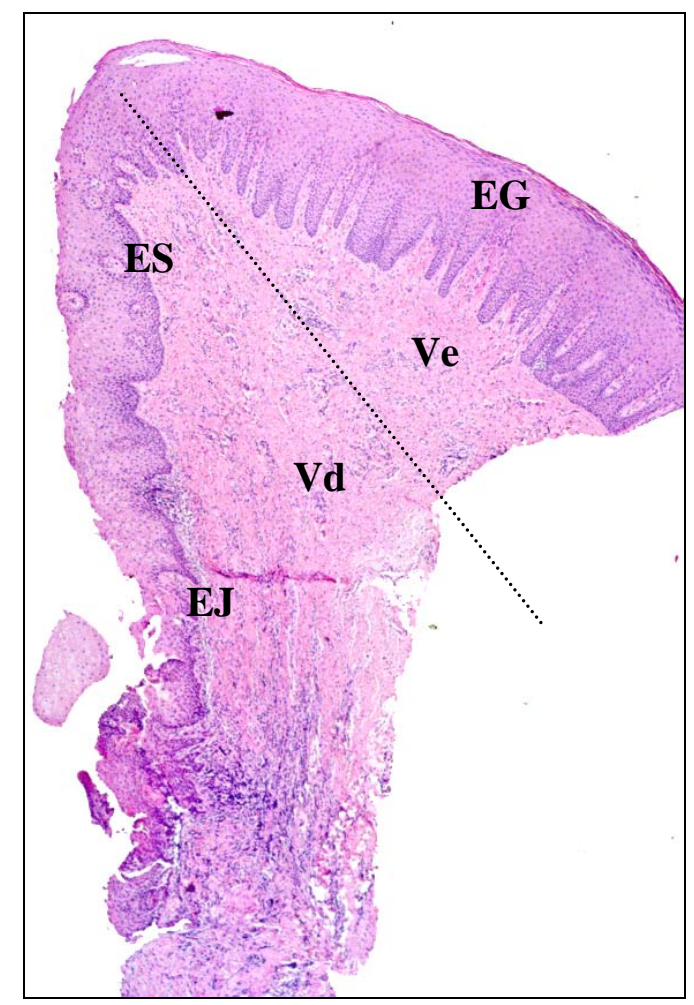

Figura 7: Visão panorâmica da gengiva marginal de paciente fumante. Observar na vertente externa (Ve) epitélio gengival (EG) normal e na vertente dentária (Vd) o epitélio sulcular (ES) e juncional (EJ) com moderada hiperplasia. Intenso infiltrado inflamatório desde a faixa limitante entre o sulco e durante toda a extensão da bolsa. HE, 38X.

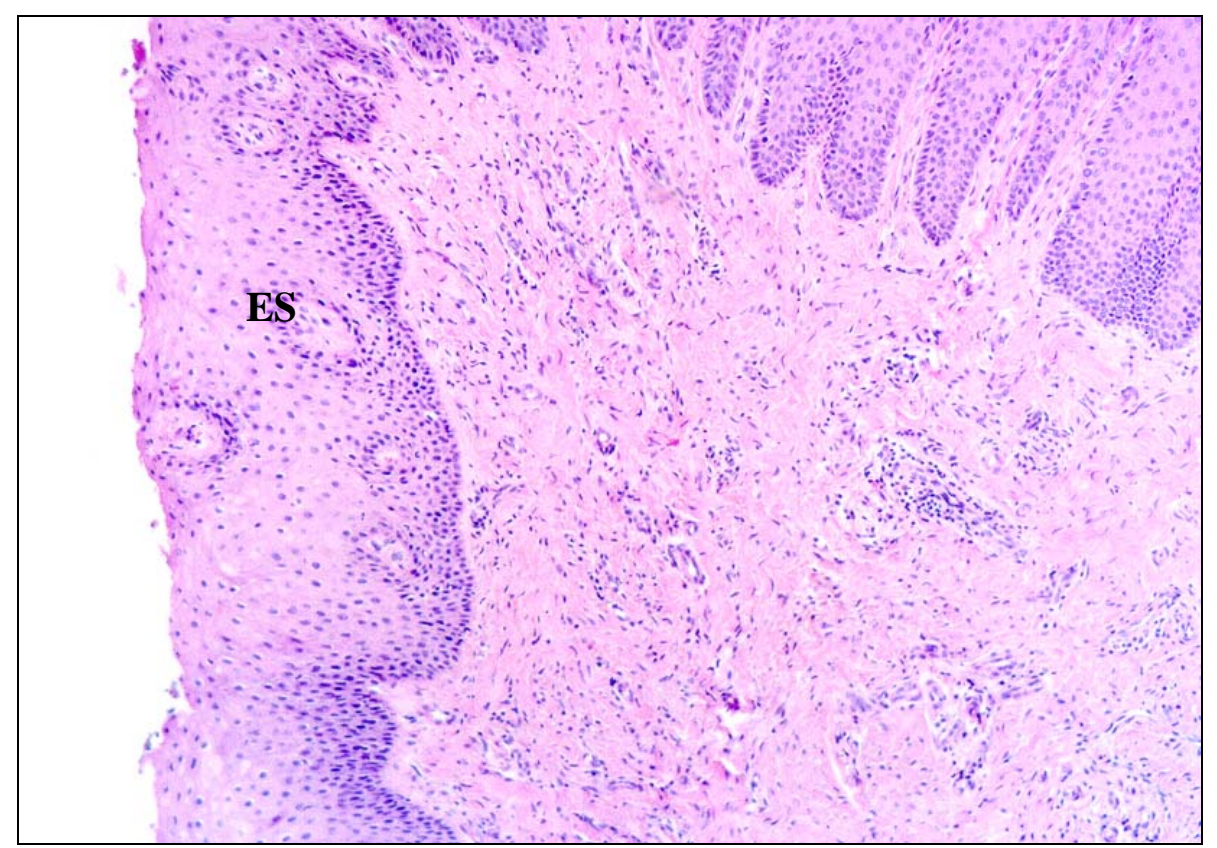

Figura 8: Detalhe da figura anterior (paciente fumante), mostrando hiperplasia do epitélio sulcular (ES), sem projeções epiteliais. HE, 96X. 


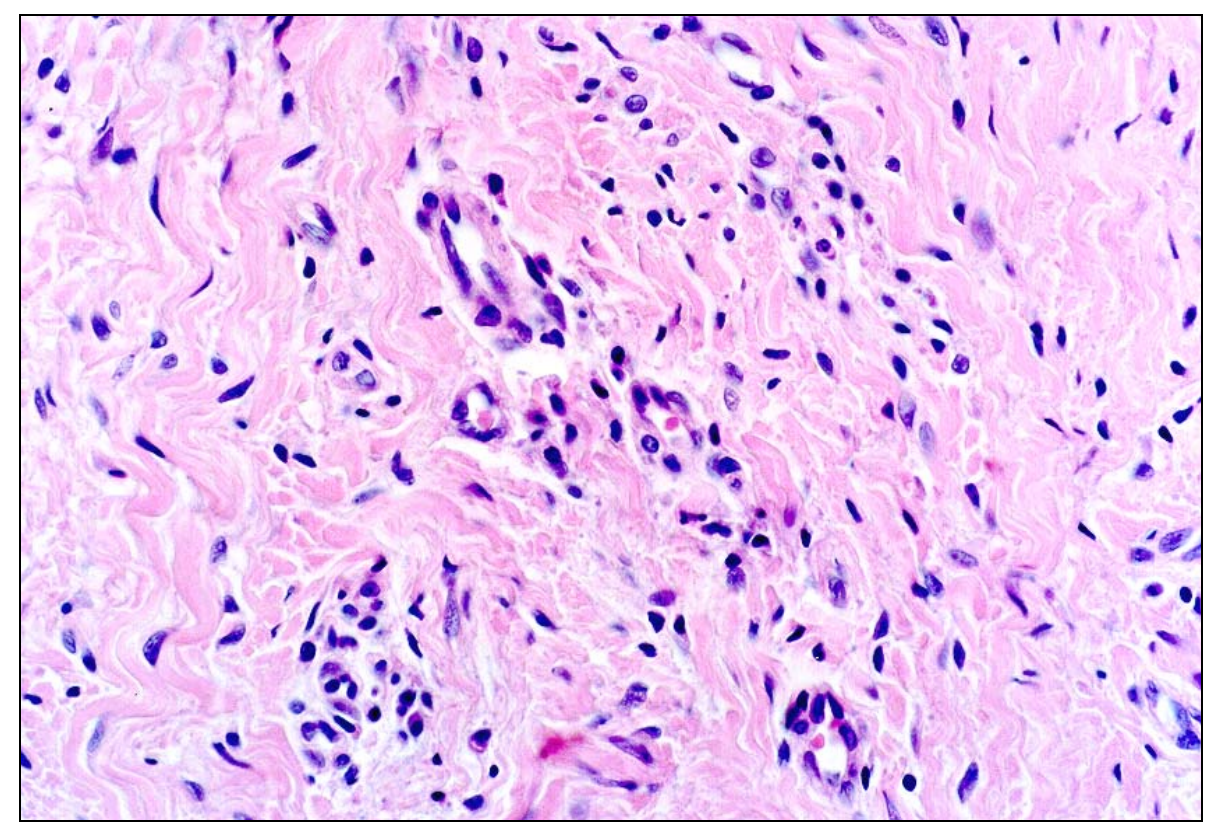

Figura 9: Detalhe da figura anterior (paciente fumante) na região da lâmina própria do epitélio sulcular, exibindo fibras colágenas densas (asterisco), fibroblastos (setas largas) e raras células inflamatórias (setas), na maioria linfócitos, localizados na região próxima de vasos. HE, 384X.

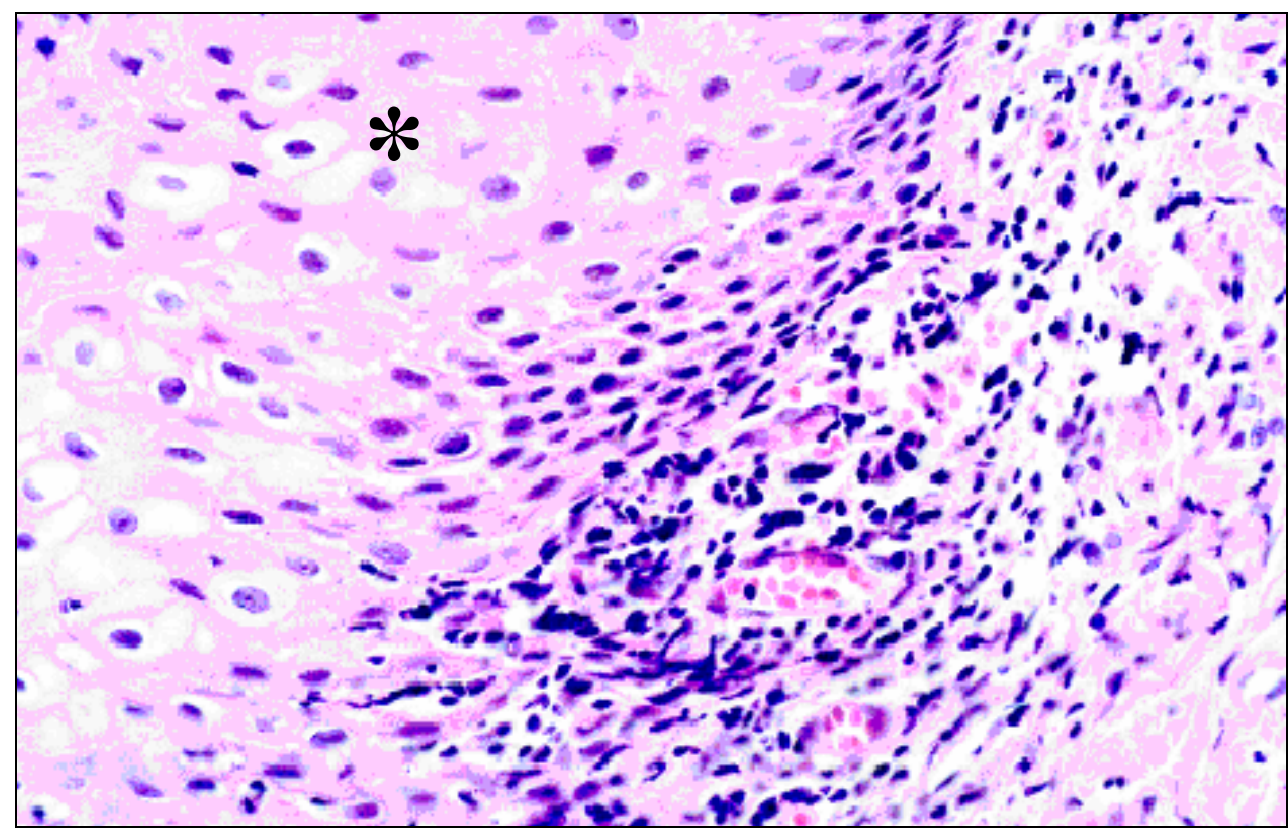

Figura 10: Região mais cervical do epitélio juncional (paciente fumante) mostra hiperplasia do extrato suprabasal (asterisco). A lâmina própria associada ao epitélio apresenta intenso infiltrado inflamatório. HE, $384 \mathrm{X}$. 


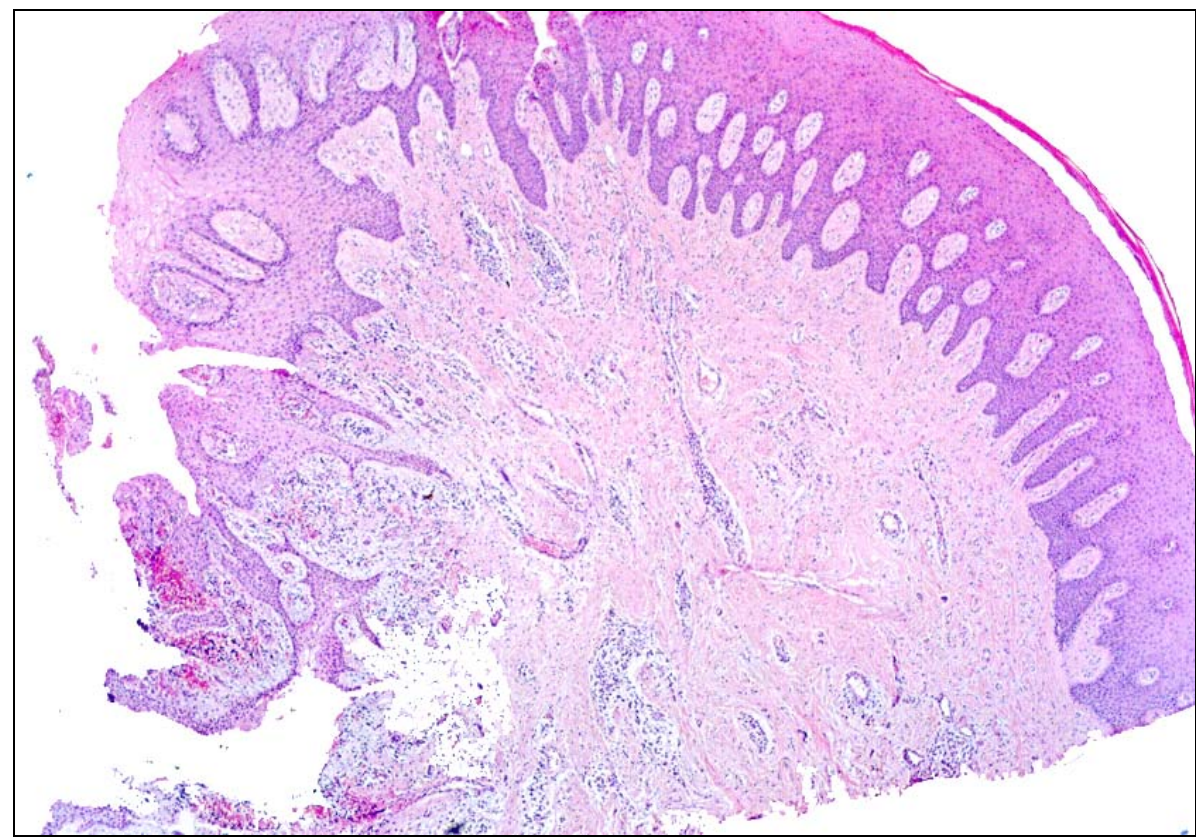

Figura 11: Visão panorâmica da gengiva marginal de paciente fumante. Observar epitélio sulcular (ES) hiperplásico com projeções epitélias em forma de espículas (setas) e fragmentos de epitélio juncional (EJ) associadas à intensa área inflamatória (asterisco) HE, 38X

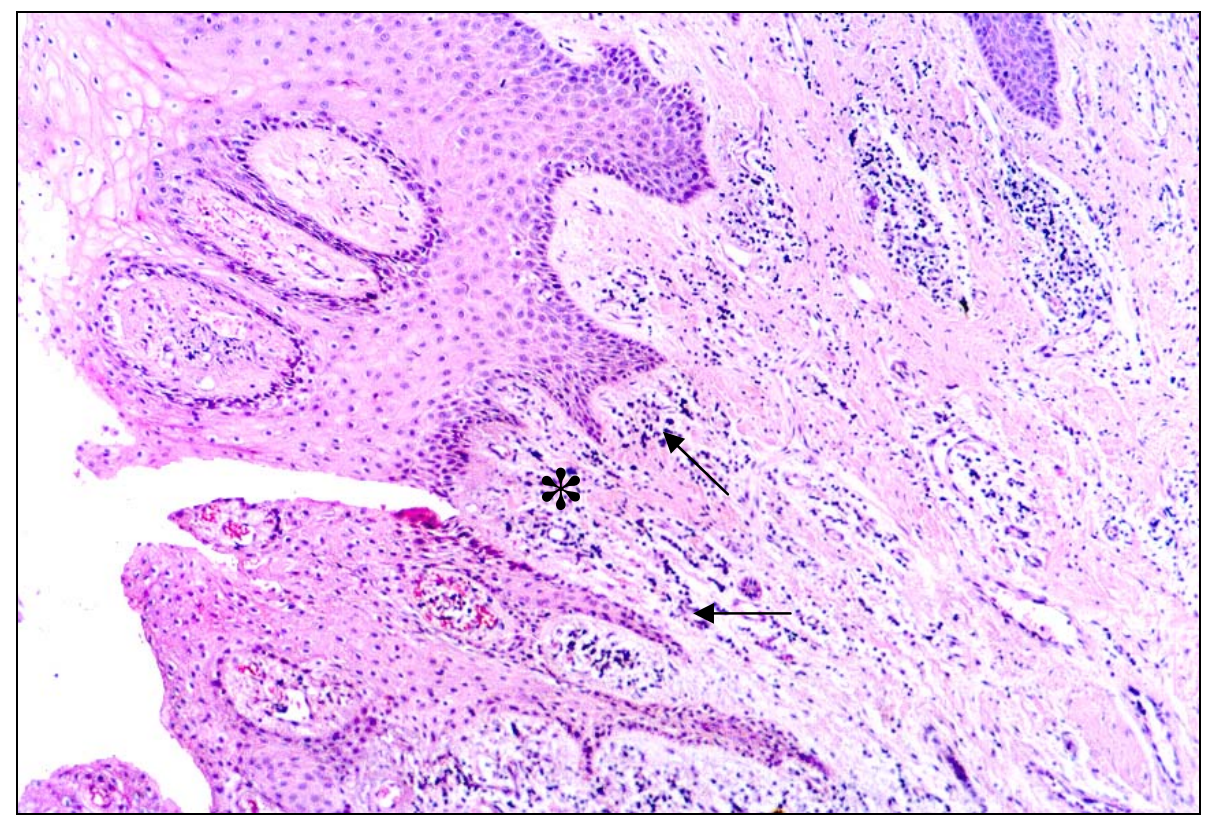

Figura 12: Detalhe da figura anterior (paciente fumante), mostrando desorganização do epitélio juncional da vertente dentária com inúmeras projeções irregulares do epitélio em forma de espículas (setas) associadas a áreas de infiltrado inflamatório (asterisco). HE, 96X. 


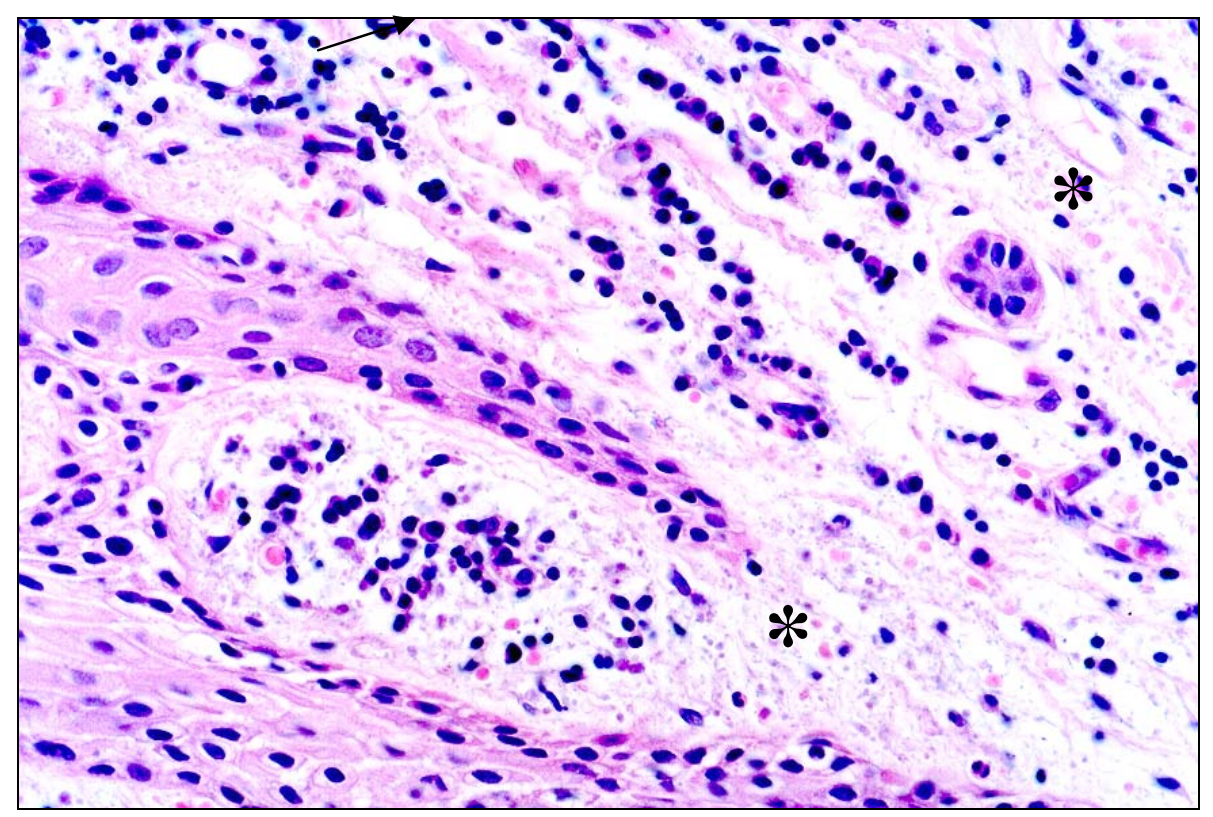

Figura 13 Detalhe da figura anterior (paciente fumante), mostrando intenso infiltrado inflamatório linfoplasmocitário (setas) e degradação das fibras colágenas (asterisco), HE, 384X.

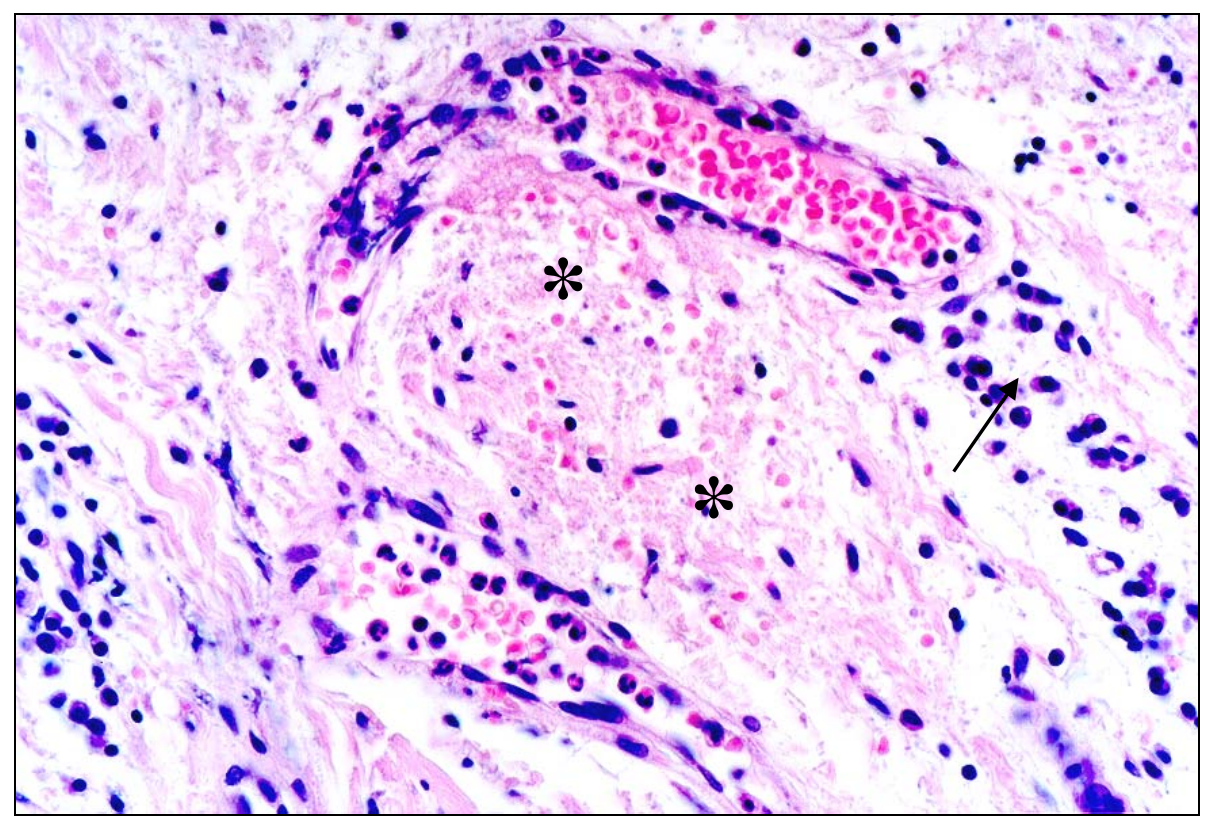

Figura 14: Detalhe do infiltrado inflamatório(paciente fumante), exibindo fibras colágenas dissociadas (asteriscos), hiperemia vascular e células inflamatórias (seta) perivascular. HE, 384X. 


\section{b) Pacientes não-fumantes}

A análise histológica da gengiva marginal dos pacientes nãofumantes mostrou na grande maioria (3 biópsias) quadro inflamatório mais acentuado que a do grupo dos fumantes.

Em geral, apresentou vertente externa, revestida pelo epitélio escamoso estratificado ceratinizado com hiperplasia e papilas de arranjo desorganizado (Figura 15). O tecido conjuntivo da lâmina própria mostrou-se constituído por fibras colágenas espessas, grande número de vasos hiperêmicos e células inflamatórias de arranjo difuso. $O$ epitélio do sulco exibiu-se estratificado, pavimentoso, não ceratinizado, com intensa hiperplasia, levando ao substancial aumento da sua espessura e a formação de projeções epiteliais (Figura 16). Associado a esta camada, presenciou-se tecido conjuntivo denso com inúmeras células inflamatórias com arranjo difuso ou em formações granulomatosas (Figuras 16 e 17). O processo inflamatório apresentou gradativo aumento ao longo do sulco em direção ao epitélio juncional (comparar Figura 18 com 19) com inúmeros linfócitos, plasmócitos e macrófagos concentrados principalmente próximos a vasos sanguíneos (Figura 20).

Dois outros pacientes apresentaram quadro histopatológico mais brando em relação ao epitélio, mas com discreta hiperplasia e com processo inflamatório mais intenso no tecido conjuntivo próximo ao epitélio sulcular e juncional, com algumas células inflamatórias invadindo o epitélio. No tecido conjuntivo da lâmina própria mais profunda, presença de áreas dispersas de tecido inflamatório com predominância de linfócitos e plasmócitos e degradação das fibras colágenas (Figuras 21 e 22). 

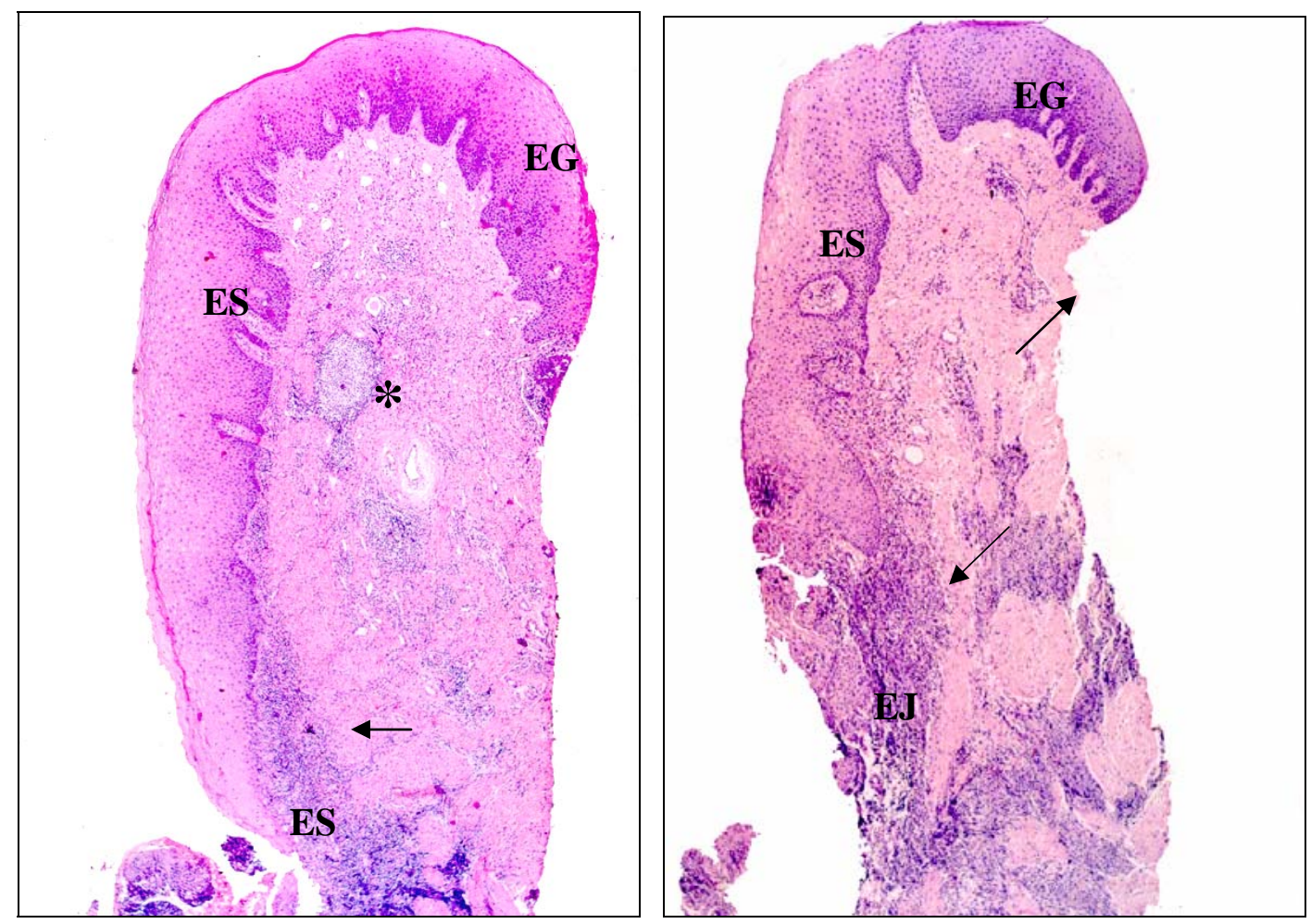

Figura 15: Visão panorâmica da gengiva marginal de 2 pacientes não-fumantes. Observar na vertente externa o epitélio gengival (EG) com ausência das características papilares, o epitélio sulcular (ES) hiperplásico e juncional (EJ) associado a áreas de infiltrado inflamatório (setas) que ao longo da lâmina própria apresentou-se em arranjo, alguns difusos com algumas formações granulomatosas (asterisco). HE, 38X.

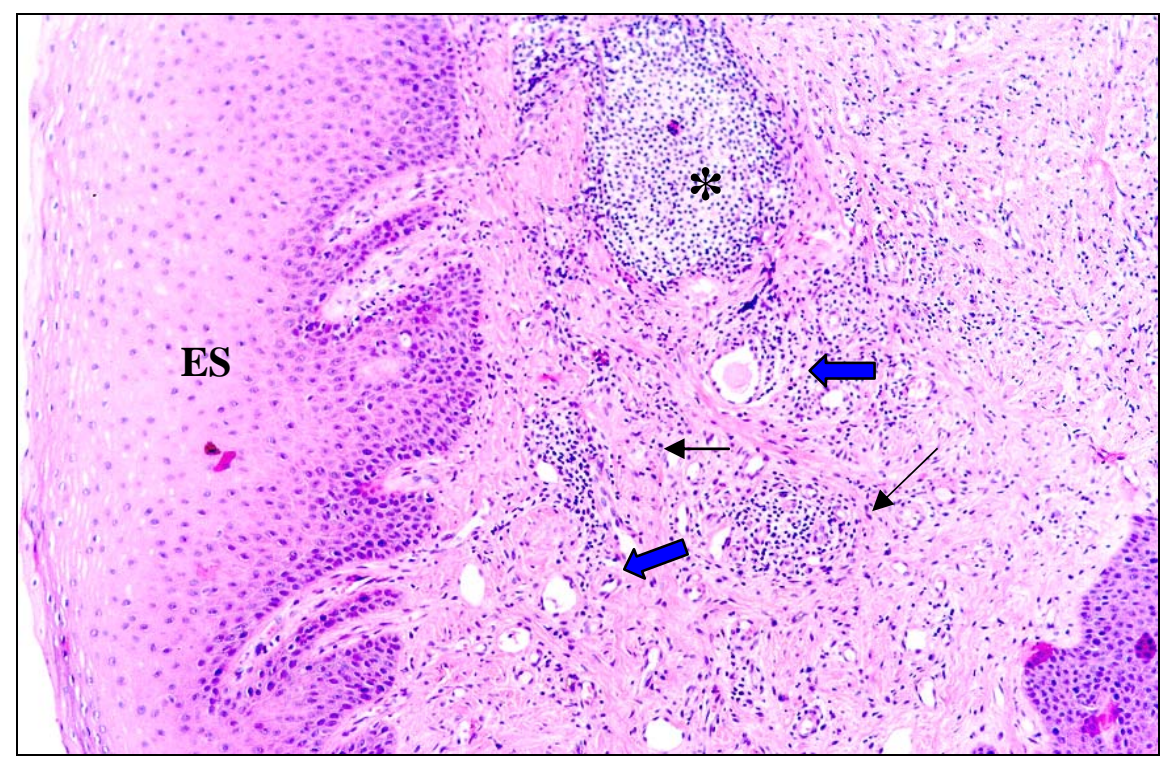

Figura 16: Detalhe da figura anterior, mostrando hiperplasia do epitélio do sulco, áreas de infiltrado inflamatório (setas) dispersos na lâmina própria e presença de formações granulomatosas (asterisco). Notar a presença de inúmeros vasos hiperêmicos (setas largas). HE, 96X 


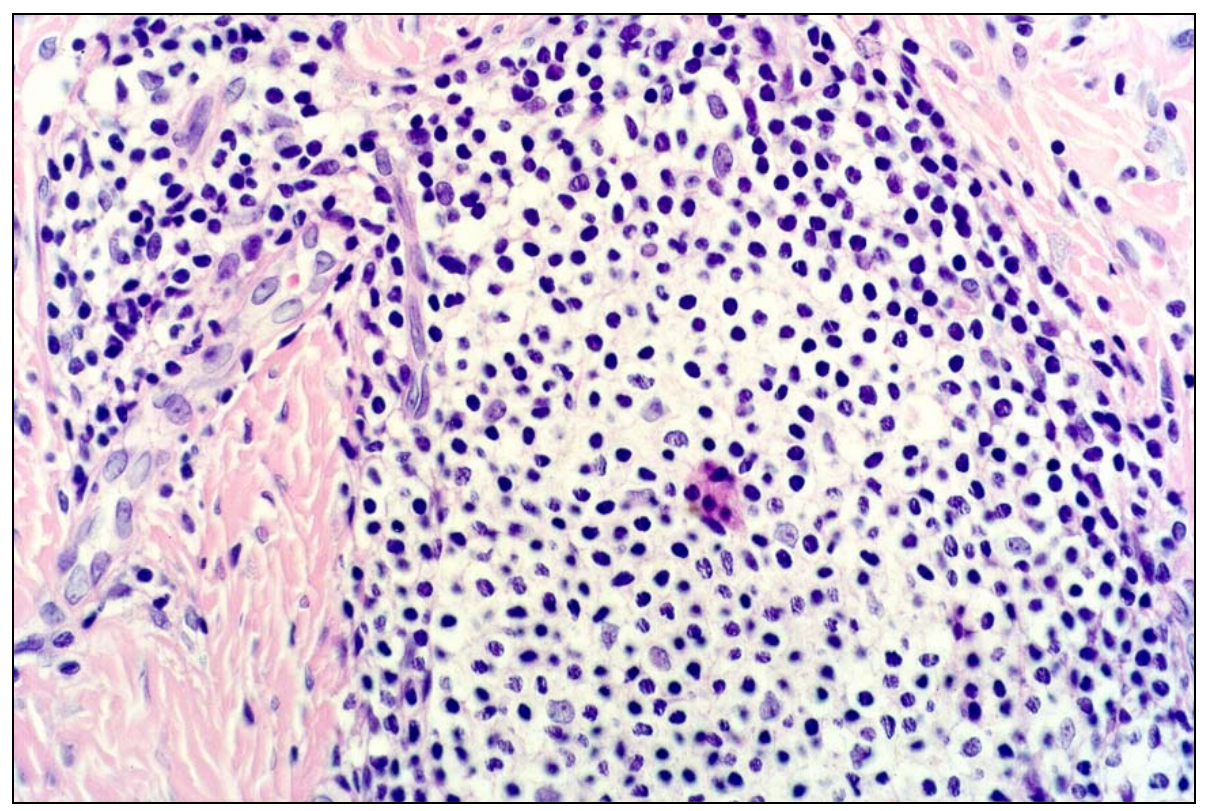

Figura 17: Detalhe da formação granulomatosa no interior da lâmina própria(paciente não fumante) com presença de linfócitos e macrófagos. HE, 384X

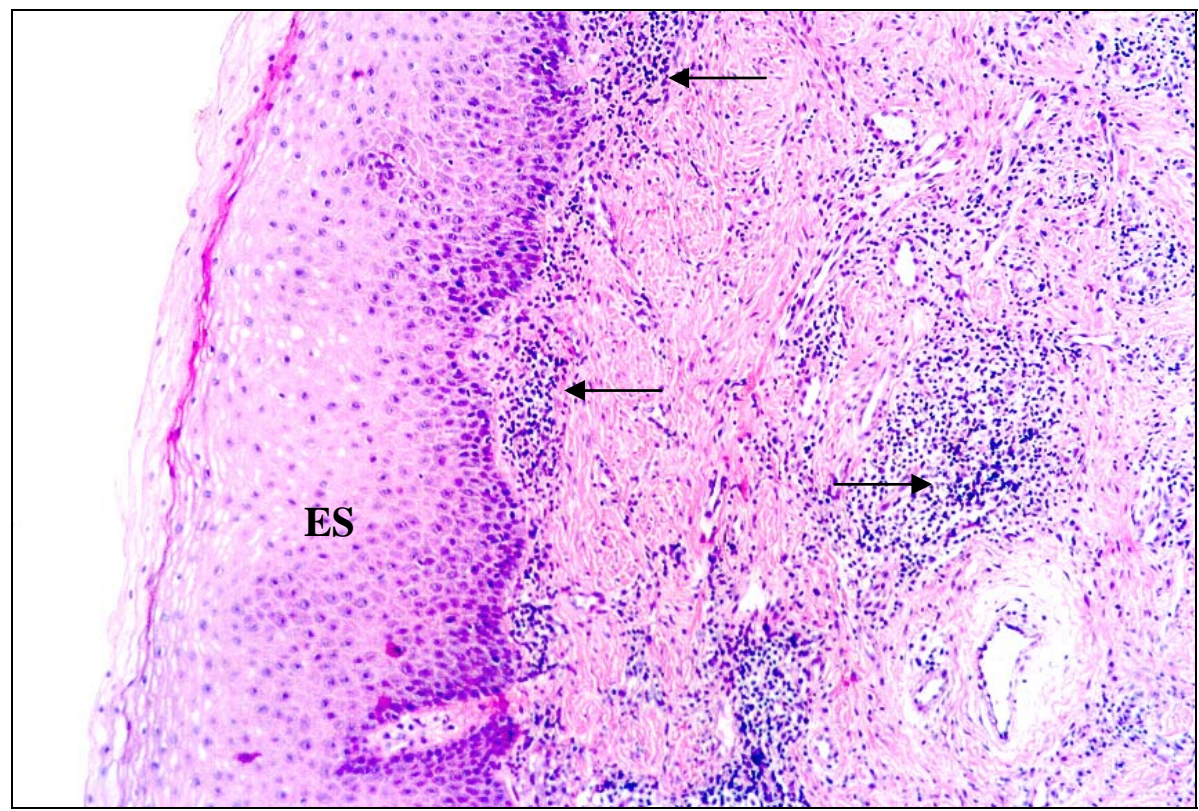

Figura 18: Detalhe( paciente não fumante) do infiltrado inflamatório (setas) disperso por todo o tecido conjuntivo da lâmina própria do epitélio sulcular (ES). HE, 96X. 


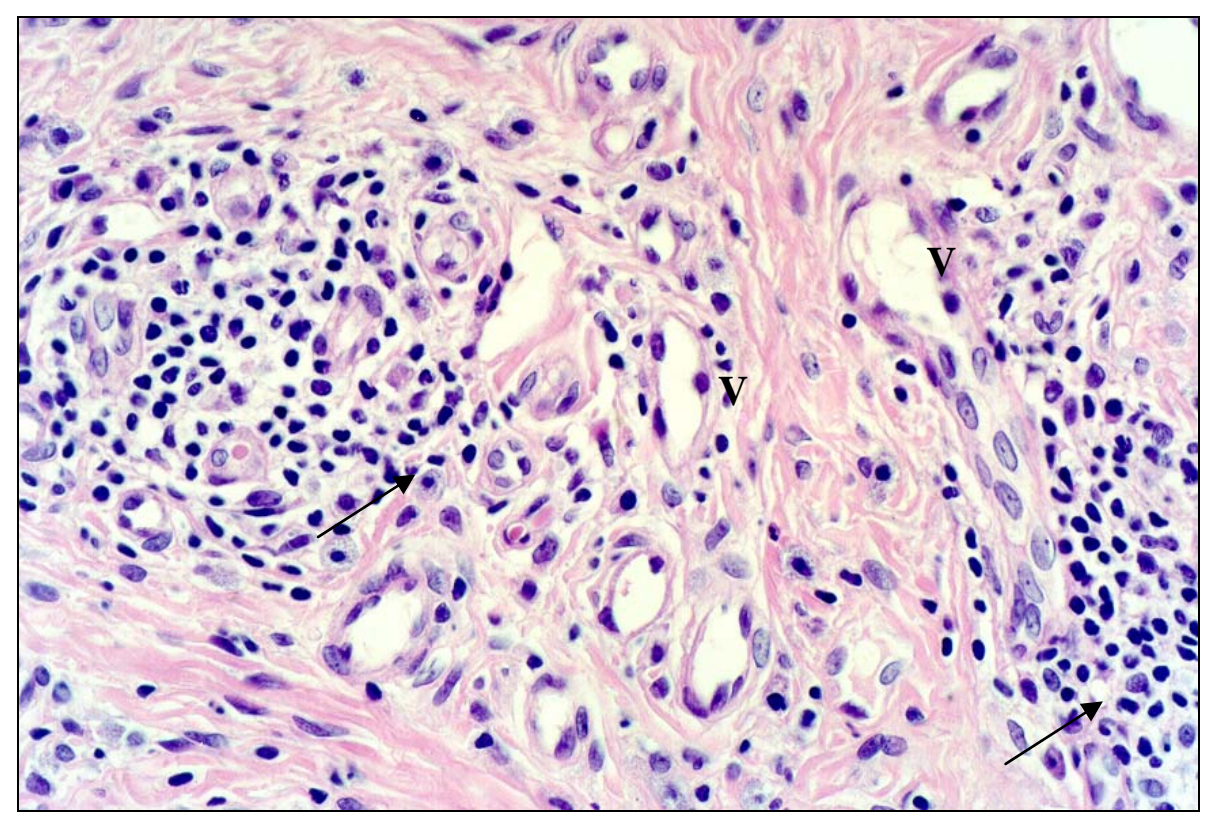

Figura 19: Lâmina própria de paciente não fumante, apresentando áreas densamente vascularizadas $(V)$ com células inflamatórias na região perivascular. HE, 384X

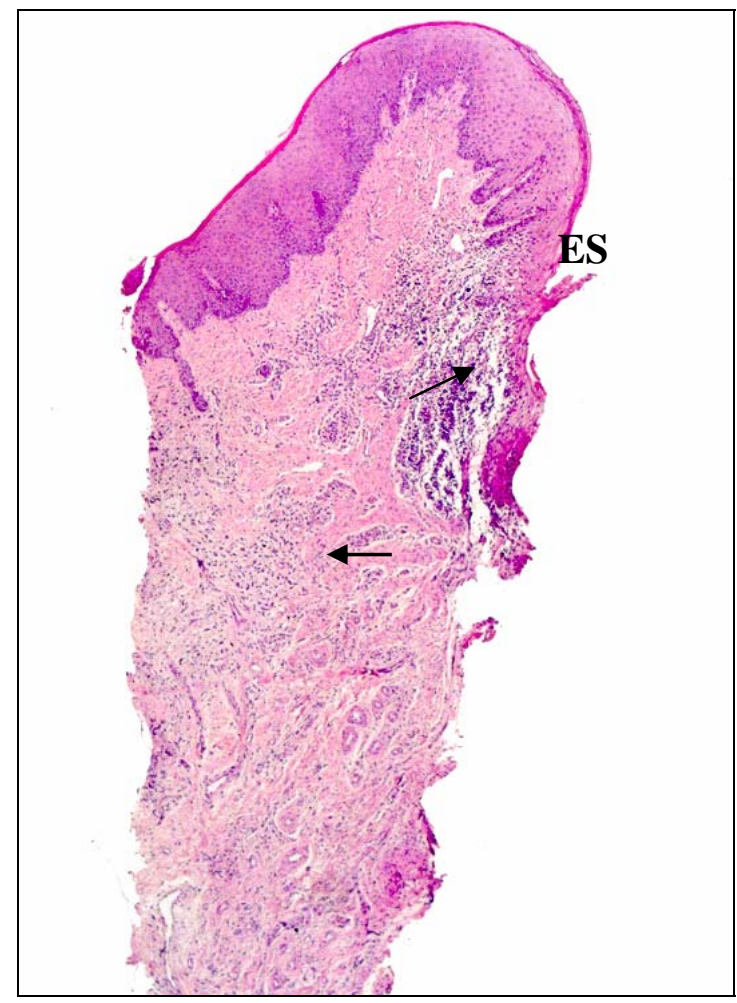

Figura 20: Gengiva de paciente não fumante. Observar neste caso intenso infiltrado inflamatório (setas) no tecido conjuntivo próximo ao epitélio do sulco (ES) e também, dispersos por toda a lâmina própria desde a vertente dentária até a vertente externa. $\mathrm{HE}, 38 \mathrm{X}$. 


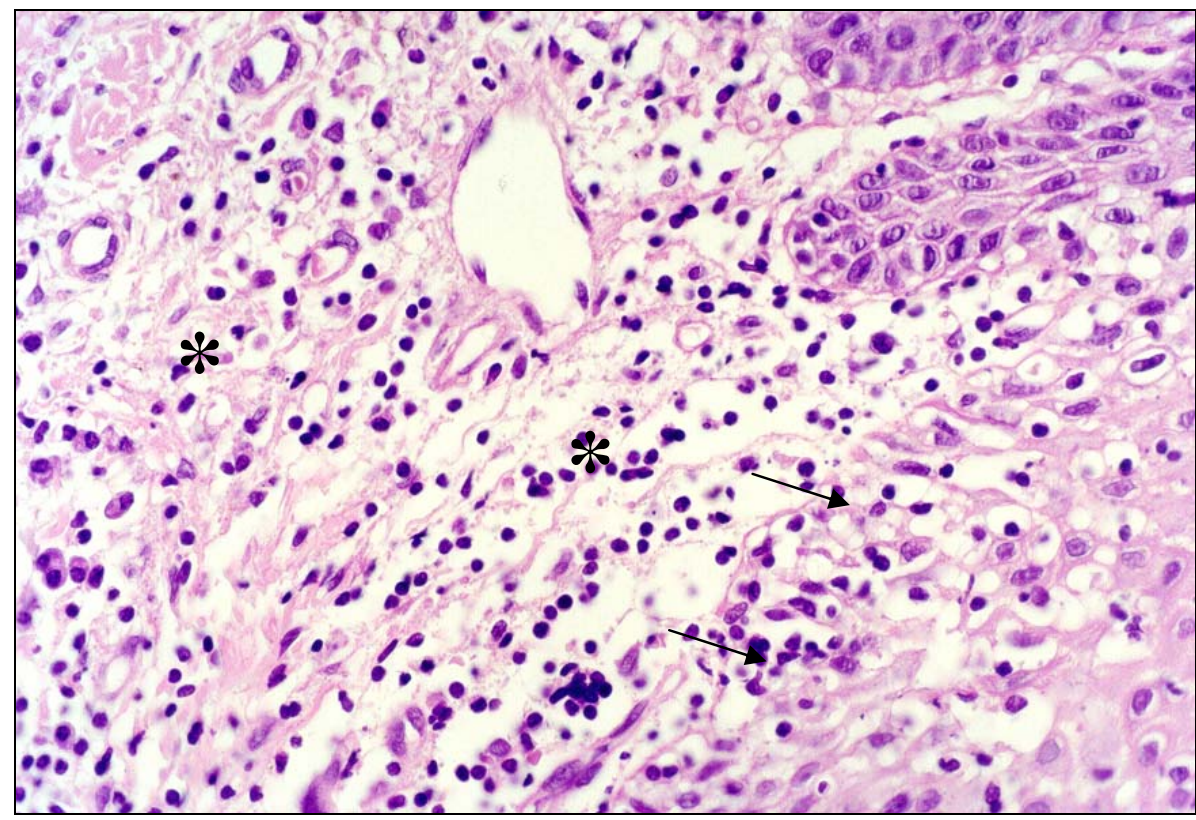

Figura 21: Detalhe do processo inflamatório próximo ao epitélio com degradação das fibras colágenas (asterisco) e invasão de células inflamatórias (setas) para o interior do epitélio. HE, 384X.

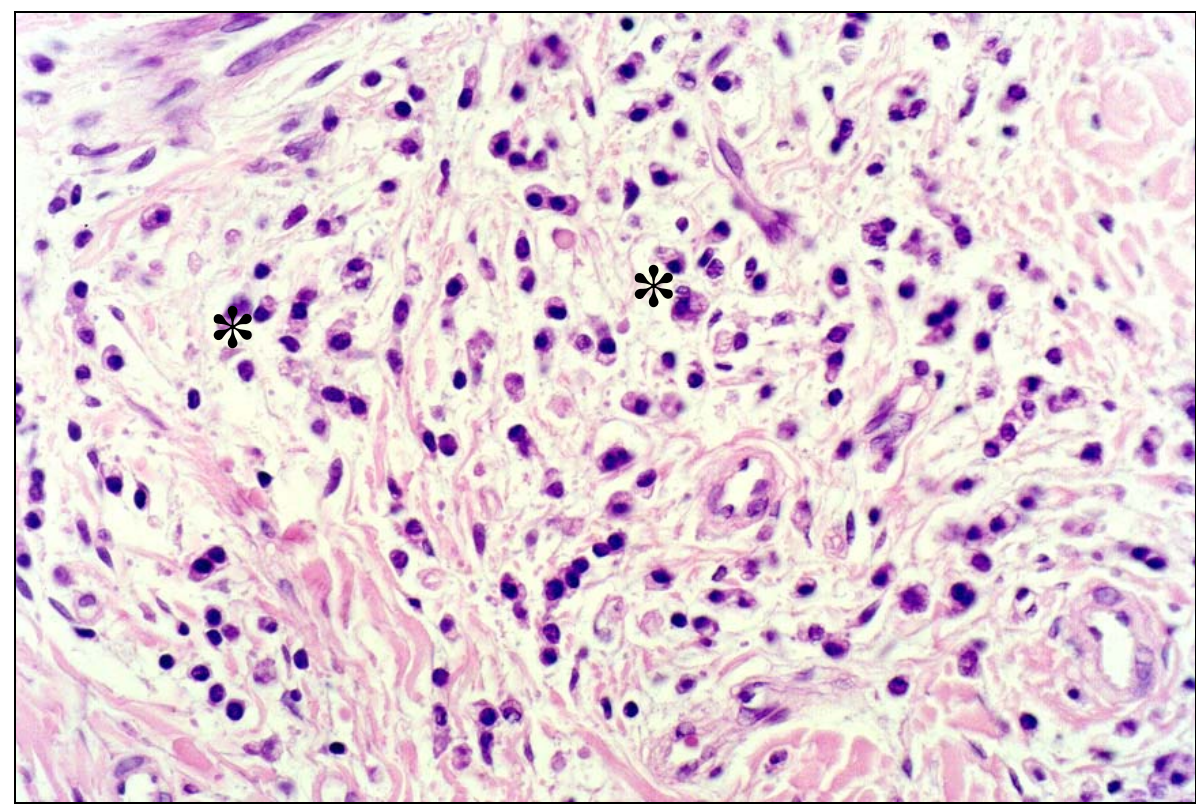

Figura 22: Camada reticular da lâmina própria, apresentando infiltrado linfoplasmocitário com degradação das fibras colágenas (asterisco). HE, 384X. 


\subsection{RESULTADOS COMPARATIVOS DO TESTE " $\mathrm{t}$ " DE STUDENT $\mathrm{E}$ DO COEFICIENTE DE CORRELAÇÃO DE PEARSON DAS VARIÁVEIS CLÍNICAS E HISTOMORFOMÉTRICAS}

Do total de pacientes fumantes e não-fumantes, foram selecionados 5 pacientes de cada grupo, que apresentassem bolsa periodontal na região palatina de dentes posteriores com PS $\geq 5 \mathrm{~mm}$ e que seriam submetidos a procedimentos cirúrgicos periodontais.

Desses locais, pôde-se obter um fragmento gengival relacionado à área da bolsa, que seria naturalmente descartado, mas que foi utilizado como peça para análise histomorfológica e histomorfométrica,

Nesses sítios(palatinos) os dados clínicos relativos à PS,IG,ISG e IP de ambos os grupos(fumantes e não-fumantes)foram analisados, assim como os dados histomorfométricos(densidade de volume: Tecido conjuntivo normal (TN) e Tecido conjuntivo inflamado (TI), células inflamatórias e fibroblastos). 
Tabela 7: Análise comparativa (Teste "t" Student) das variáveis clínicas (PS,IG,ISG,IP) e histomorfométricas(TN,TI,CEL.INF.,FIBROB.) dos 10 pacientes operados

\begin{tabular}{|c|c|c|c|c|c|c|}
\hline \multirow[b]{2}{*}{ Variáveis } & \multicolumn{2}{|c|}{ Fumantes $n=5$} & \multicolumn{2}{|c|}{ Não-fumantes $n=5$} & \multirow[b]{2}{*}{$\mathbf{t}$} & \multirow[b]{2}{*}{$\mathbf{p}$} \\
\hline & $\bar{X}$ & $D p$ & $\bar{x}$ & $d p$ & & \\
\hline PS mm & 6,20 & 1,09 & 6,20 & 1,09 & 0,000 & 1,000 \\
\hline IG & $0,80^{*}$ & $1,09^{*}$ & $2,60^{*}$ & $0,54^{*}$ & $3,286^{*}$ & $0,011^{*}$ \\
\hline$\overline{I S G}$ & 1,00 & 0,00 & 1,00 & 0,00 & -- & -- \\
\hline $\mathrm{IP}$ & 1,40 & 0,54 & 1,20 & 1,30 & 0,316 & 0,759 \\
\hline TN (\%) & $74,15^{*}$ & $11,19^{*}$ & $53,4^{*}$ & $5,53^{*}$ & $2,320^{*}$ & $0,044^{*}$ \\
\hline TI (\%) & $25,85^{*}$ & $11,26^{*}$ & $46,60^{*}$ & $5,53^{*}$ & $2,380^{*}$ & $0,044^{*}$ \\
\hline CEL.INF./mm ${ }^{3}$ & $54,98^{*}$ & $34,14^{*}$ & $108,67^{*}$ & $34,15^{*}$ & $2,485^{*}$ & $0,037^{*}$ \\
\hline FIBROB. $/ \mathrm{mm}^{3}$ & 65,78 & 27,60 & 55,87 & 11,37 & 0,742 & 0,479 \\
\hline
\end{tabular}

$p<0,05^{*}$ : estatisticamente significante

PS-profundidade de sondagem IG: Índice Gengival ISG: Índice de sangramento gengival IP: Indice de placa TN: Tecido conjuntivo gengival normal TI: Tecido conjuntivo inflamado Cel. Infl.: células inflamatórias Fibrob.:fibroblastos

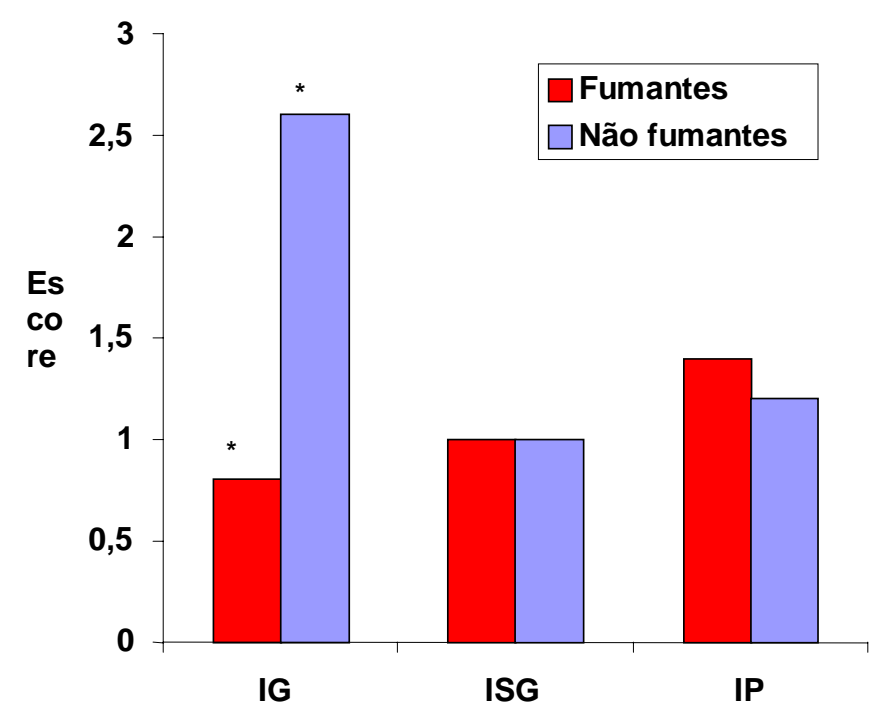

Figura 23: Gráfico da análise comparativa das variáveis clínicas(IG,ISG,IP)dos 10 pacientes operados. 


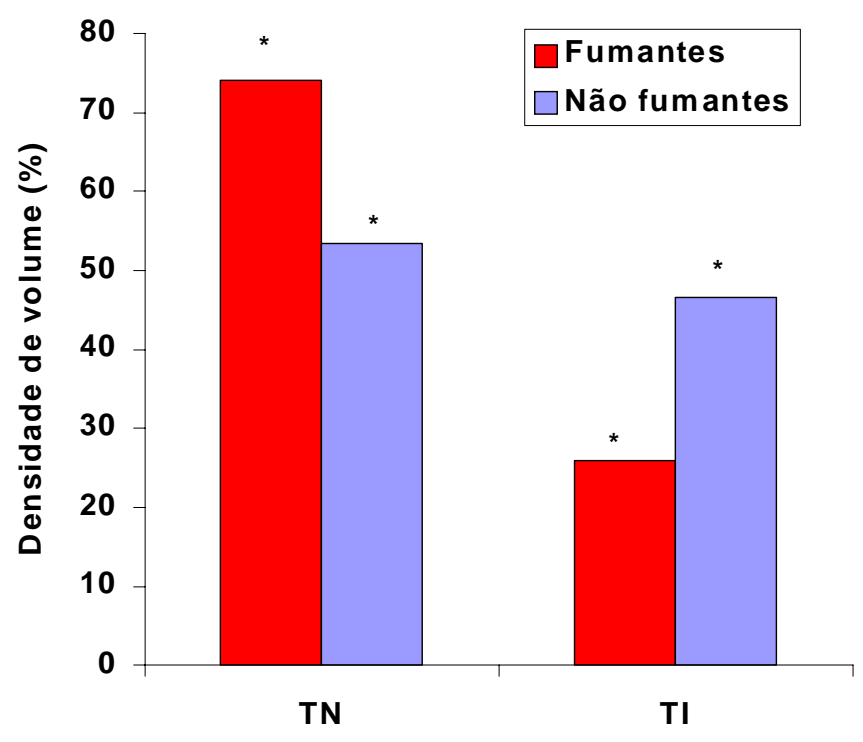

Figura 24: Gráfico da análise comparativa da densidade de volume de tecido normal (TN) e inflamado ( $\mathrm{TI})$ da lâmina própria da gengiva marginal dos 10 pacientes operados

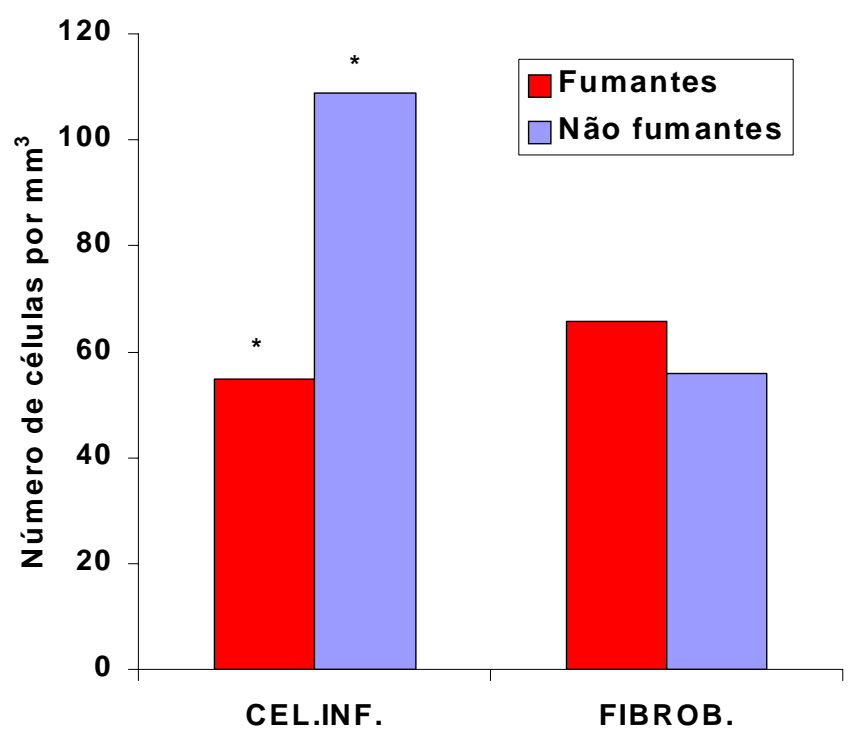

Figura 25: Gráfico do número total de células inflamatórias e fibroblastos da lâmina própria da gengiva marginal dos 10 pacientes operados 
Na Tabela 7 e Figura 23, pôde-se verificar quanto às variáveis clínicas dos 10 pacientes selecionados para o exame histológico que houve diferença estatisticamente significante apenas para o IG, apresentando média maior no grupo de não-fumantes.

Em relação aos parâmetros histomorfométricos (Tabela 7, Figuras 24 e 25) houve significância estatística para o infiltrado celular inflamatório, TN e TI (Figura 24), sendo maiores os valores médios de infiltrado inflamatório(CEL.INF.) e tecido inflamado(TI) para os indivíduos não-fumantes e maior média de TN para o grupo fumantes.

Tabela 8: Coeficiente de Correlação de Pearson das variáveis clínicas (PS,IG,ISG,IP) e histomorfométricas (TN,TI,CEL.INFL.,FIBROB.) dos 10 pacientes operados, fumantes e não-fumantes, em área de bolsa periodontal

\begin{tabular}{c|c|c|c|c}
\hline \hline \multirow{2}{*}{ Variáveis } & TN & TI & CEL.INFL. & FIBROB. \\
\hline \hline PS & 0,305 & $-0,359$ & $-0,277$ & 0,349 \\
& $\mathrm{p}=0,391$ & $\mathrm{p}=0,294$ & $\mathrm{p}=0,439$ & $\mathrm{p}=0,323$ \\
\hline IG & $-0,277$ & 0,213 & 0,224 & 0,193 \\
& $\mathrm{p}=0,437$ & $\mathrm{p}=0,055$ & $\mathrm{p}=0,532$ & $\mathrm{p}=0,592$ \\
\hline ISG & -- & -- & -- & - \\
\hline IP & 0,059 & $-0,013$ & 0,312 & $-0,248$ \\
& $\mathrm{p}=0,870$ & $\mathrm{p}=0,970$ & $\mathrm{p}=0,379$ & $\mathrm{p}=0,488$ \\
\hline
\end{tabular}

$p<0,05^{*}$ : estatisticamente significante

PS-profundidade de sondagem IG: Índice Gengival ISG: Índice de sangramento gengival IP: Índice de placa TN: Tecido conjuntivo gengival normal TI: Tecido conjuntivo inflamado Cel. Infl.: células inflamatórias Fibrob.:fibroblastos 
$\mathrm{Na}$ Tabela 8, observam-se valores positivos e negativos de acordo com o tipo de correlação de variáveis clínicas (PS,IG,ISG,IP) e histomorfométricas (TN,TI,CEL.INFL.,FIBROB.) de 10 pacientes selecionados. Quando da correlação desses parâmetros, não se constatou significância. Entretanto, na correlação positiva do IG com TI, quase houve significância.

Tabela 9: Coeficiente de Correlação de Pearson das variáveis clínicas (PS,IG,ISG,IP) e histomorfométricas (TN,TI,CEL.INFL.,FIBROB.) de 5 pacientes fumantes, em área de bolsa periodontal

\begin{tabular}{c|c|c|c|c}
\hline \hline \multirow{2}{*}{ Variáveis } & TN & TI & CEL.INFL. & FIBROB. \\
\hline \hline PS & 0,736 & $-0,735$ & $-0,842$ & 0,727 \\
& $\mathrm{p}=0,156$ & $\mathrm{p}=0,157$ & $\mathrm{p}=0,73$ & $\mathrm{p}=0,164$ \\
\hline IG & 0,814 & $-0,813$ & $-0,886^{*}$ & 0,808 \\
& $\mathrm{p}=0,093$ & $\mathrm{p}=0,093$ & $\mathrm{p}=0,045^{*}$ & $\mathrm{p}=0,98$ \\
\hline ISG & -- & -- & -- & -- \\
\hline IP & $-0,111$ & 0,111 & 0,608 & $-0,418$ \\
& $\mathrm{p}=0,858$ & $\mathrm{p}=0,859$ & $\mathrm{p}=0,277$ & $\mathrm{p}=0,483$ \\
& & & & \\
\hline
\end{tabular}

$p<0,05^{*}$ : estatisticamente significante

PS-profundidade de sondagem IG: Índice Gengival ISG: Índice de sangramento gengival IP: Índice de placa TN: Tecido conjuntivo gengival normal TI: Tecido conjuntivo inflamado Cel. Infl.: células inflamatórias Fibrob.:fibroblastos

A análise dos 5 indivíduos fumantes (Tabela 9) mostra que houve correlação negativa significante entre IG e Infiltrado inflamatório. 
Tabela 10: Coeficiente de Correlação de Pearson das variáveis clínicas (PS,IG,ISG,IP) e histomorfométricas (TN,TI,CEL.INFL.,FIBROB.)de 5 pacientes não-fumantes, em área de bolsa periodontal

\begin{tabular}{c|c|c|c|c}
\hline \multirow{2}{*}{ Variáveis } & TN & TI & CEL.INFL. & FIBROB. \\
\hline \hline PS & 0,001 & $-0,008$ & 0,105 & $-0,425$ \\
& $\mathrm{p}=0,998$ & $\mathrm{p}=0,989$ & $\mathrm{p}=0,867$ & $\mathrm{p}=0,476$ \\
\hline IG & $-0,524$ & 0,527 & $-0,005$ & $-0,333$ \\
& $\mathrm{p}=0,365$ & $\mathrm{p}=0,361$ & $\mathrm{p}=0,993$ & $\mathrm{p}=0,584$ \\
\hline ISG & -- & -- & -- & -- \\
\hline IP & $-0,08$ & 0,09 & 0,538 & $-0,394$ \\
& $\mathrm{p}=0,890$ & $\mathrm{p}=0,884$ & $\mathrm{p}=0,350$ & $\mathrm{p}=0,512$ \\
\hline
\end{tabular}

$p<0,05^{*}$ : estatisticamente significante

PS-profundidade de sondagem IG: Índice Gengival ISG: Índice de sangramento gengival IP: Índice de placa TN: Tecido conjuntivo gengival normal TI: Tecido conjuntivo inflamado Cel. Infl.: células inflamatórias Fibrob.:fibroblastos

Observou-se, que nos 5 pacientes não-fumantes (Tabela 10), não houve significância estatística na correlação das variáveis clínicas (PS,IG,ISG,IP) e histomorfométricas (TN,TI,CEL.INFL.,FIBROB.).

Tabela 11: Análise comparativa do número de dentes ausentes por área (anterior e posterior) e arcada(superior e inferior) dos grupos de indivíduos fumantes e não-fumantes(n.55)

\begin{tabular}{|c|c|c|c|c|c|c|}
\hline \multirow[b]{2}{*}{ Regiões } & \multicolumn{2}{|c|}{ Fumantes } & \multicolumn{2}{|c|}{ Não-fumantes } & \multirow[b]{2}{*}{$\mathbf{T}$} & \multirow[b]{2}{*}{$\mathbf{p}$} \\
\hline & $\bar{x}$ & $d p$ & $\bar{x}$ & Dp & & \\
\hline$\overline{P \text { PS }}$ & 3,55 & 2,11 & 3,15 & 1,99 & 0,715 & 0,477 \\
\hline AS & 0,75 & 1,35 & 0,65 & 1,26 & 0,295 & 0,768 \\
\hline $\mathrm{PI}$ & 4,06 & 1,98 & 4,19 & 2,02 & $-0,228$ & 0,820 \\
\hline$\overline{\mathrm{Al}}$ & 0,00 & 0,00 & 0,19 & 0,63 & $-0,163$ & 0,107 \\
\hline
\end{tabular}

$p<0,05^{*}$ : estatisticamente significante 
Ao se comparar os grupos de fumantes e não-fumantes, quanto à quantidade de dentes ausentes (Tabela 11), considerando regiões anteriores e posteriores, superiores e inferiores, as diferenças não se mostraram estatisticamente significantes, embora tenha havido uma tendência de maior perda de dentes superiores nos fumantes e maior perda de dentes inferiores nos não-fumantes.

Tabela 12: Coeficiente de correlação de Pearson de dentes ausentes (DA) por área (anterior e posterior) e arcada (superior e inferior) em função do número de cigarros/dia(29) e tempo do vício/ano(23)

\begin{tabular}{c|c|c}
\hline \hline \multirow{2}{*}{ Regiões } & $\begin{array}{c}\text { Cigarro/dia } \\
\text { 29 cigarros }\end{array}$ & $\begin{array}{c}\text { Tempolano } \\
\text { 23 anos }\end{array}$ \\
\hline \hline \multirow{2}{*}{ DAPS } & 0,125 & 0,121 \\
& $\mathrm{p}=0,515$ & $\mathrm{p}=0,580$ \\
\hline DAAS & 0,340 & 0,793 \\
& $\mathrm{p}=0,70$ & $\mathrm{p}=0,719$ \\
\hline DAPI & 0,209 & $0,491^{*}$ \\
& $\mathrm{p}=0,291$ & $\mathrm{p}=0,017^{*}$ \\
\hline DAAI & -- & -- \\
\hline
\end{tabular}

$p<0,05^{\star}$ : estatisticamente significante

Dentro do grupo de fumantes(tabela 12) ao se correlacionar número de dentes ausentes com variáveis número de cigarros fumados por dia, matematicamente, não houve diferença estatisticamente significante. Nesta mesma tabela, ao se correlacionar número de dentes ausentes com o tempo do vício expresso em anos, houve diferença significante para a região postero-inferior. 
6 Discussão 


\section{Discussão}

Desde as épocas mais remotas, tem-se procurado a causa da doença periodontal. Evidentemente, neste passado mais distante, sem muitos critérios confiáveis a se basear, não se pôde estabelecer uma causa correta sobre o início e a progressão da doença periodontal. Assim, o cálculo foi inicialmente o fator associado mais evidente ${ }^{89}$.

Posteriormente, com o avanço das descobertas na área de microbiologia, pôde-se fazer uma relação mais científica da etiologia da doença periodontal, admitindo-se a importância da placa bacteriana. E assim, por muito tempo, acreditou-se que apenas a placa bacteriana era o único fator envolvido na doença periodontal. Entretanto, com a evolução das descobertas nessa área, pôde-se questionar sobre a possibilidade de outros fatores modificarem a resposta do hospedeiro, predispondo o indivíduo a um maior risco à doença. Inicialmente, esses fatores foram especulados como possibilidade e posteriormente, até os dias atuais, são admitidos como fundamentais na inter-relação resistência do hospedeiro-agressão bacteriana. Dentre os fatores, pode-se citar a predisposição hereditária, a idade, condições sistêmicas, o estresse, drogas e tabagismo, entre outros.

O tabagismo, no passado, foi admitido estar relacionado à etiologia apenas da G.U.N.A. ${ }^{90}$,entretanto, careciam explicações de como poderia atuar. Hoje, sabe-se que a ação do tabaco no periodonto é capaz de predispor o indivíduo às várias doenças periodontais e não somente à G.U.N.A. Além disso, muitas são as pesquisas tentando explicar os 
mecanismos pelos quais o tabaco interfere significativamente nas condições periodontais. Muitos dos trabalhos evidenciam aspectos da relação do tabagismo com acúmulo de placa ${ }^{4,12,14,20,21,38,80,95,96,104}$, inflamação $0^{5,15,21,53,68,80,104}$, cálculo ${ }^{2,18,89}$, resposta imune ch, $^{21,76,87}$, toxicidade $36,52,66,84$ e microbiologia da placa ${ }^{11,52,55,64,78,109,115}$. Atualmente, tem-se a condição periodontal significativamente prejudicada pela ação do tabaco $^{14,21,51,52,64}$. Apesar disso, a quantidade de pesquisas que se verifica na área, justifica-se pela necessidade da completa compreensão deste marcante fator.

Assim, o presente estudo se propôs a investigar aspectos dessa inter-relação. Para tanto, foram selecionados 60 indivíduos, entre 30 e 50 anos, portadores de periodontite crônica. Deste total, 1 fumante e 4 nãofumantes não concluíram as avaliações, permanecendo na pesquisa 29 fumantes e 26 não-fumantes.

A faixa etária dos indivíduos da pesquisa foi definida procurando excluir os muito jovens ou muito idosos. Tal aspecto foi importante para a amostra, tentando-se minimizar aspectos relativos à idade avançada que poderiam ser importantes nas condições periodontais. Por outro lado, indivíduos mais jovens também foram excluídos onde talvez os efeitos do fumo (tempo de ação) pudessem ser menos expressivos. Desta maneira, a média de idade entre os indivíduos foi de 40 anos.

Como o objetivo do estudo foi analisar comparativamente aspectos entre fumantes e não-fumantes, nenhuma instrução de higiene ou raspagem profissional foi realizada em ambos os grupos. Assim, foram 
obtidos dados relativos à profundidade de sondagem, recessão gengival, nível de inserção clínica, índice gengival, índice de sangramento gengival e índice de placa de todas as faces de todos os dentes dos indivíduos da amostra. Outro aspecto coletado e importante foi o registro do número de dentes perdidos em cada indivíduo.

A obtenção desses dados relativos aos parâmetros periodontais é básica e padrão para se aferir aspectos importantes das condições periodontais dos indivíduos. Desta maneira, utilizando todos esses registros, foi possível a comparação entre os grupos para que se pudesse analisar na amostra os reais efeitos do tabaco nas condições periodontais, podendo-se compará-los e correlacioná-los com a doença periodontal.

$\mathrm{Na}$ literatura, verificam-se estudos com casuística grande, porém, em muitos deles, os exames são realizados por muitos profissionais e até mesmo com a obtenção de dados somente de certos locais da boca, como com a utilização do $\operatorname{CPITN}^{7,43}$. Pode-se salientar que todos os registros desse estudo foram realizados por um único periodontista, previamente calibrado pelo teste KAPPA, para que houvesse uma rígida padronização, sobretudo nos exames onde a carga de subjetividade é crítica.

Ainda neste estudo, de cada grupo foram selecionados aleatoriamente 5 indivíduos, dos quais um sítio da arcada superior, área palatina, foi submetido a procedimento cirúrgico periodontal e o tecido que seria descartado foi utilizado para avaliação da condição tecidual. 
Nessa análise histológica, considerou-se a densidade de volume(\%) de tecido normal e de tecido inflamado, o número de fibroblastos e de células inflamatórias. Nesses sítios, previamente à cirurgia, foram obtidos os dados clínicos semelhantes ao obtido para todos os indivíduos, quando da comparação dos índices clínicos dos fumantes e não-fumantes. Assim, pôde-se fazer uma análise comparativa das condições clínicas e histomorfométricas, uma descrição histológica e a correlação das variáveis clínicas e histológicas de cada grupo e entre os grupos (fumantes e nãofumantes).

Os resultados obtidos neste estudo, quando se considerou os parâmetros clínicos, particularmente quanto à profundidade de sondagem (Tabela 1, Figura 1) mostram-se evidentes quanto à influência negativa do tabaco. Embora tenha havido apenas significância estatística nos sítios palatinos dos dentes posteriores é inegável a tendência de maior PS em todas as situações analisadas nos fumantes em relação aos não-fumantes. Confrontando com os trabalhos da literatura, pode-se verificar que existe concordância com o resultado desse estudo ${ }^{13,43,51,52,69,109}$. Veja-se que a prevalência de maiores profundidades de sondagens ocorre tanto para fumantes de cigarros, quanto para os de charutos ou cachimbo ${ }^{2}$.

No artigo de STOLTENBERG et al. ${ }^{109}$, os autores encontraram 5 vezes mais bolsas $\geq 3,5 \mathrm{~mm}$ em fumantes nas superfícies proximais de todos os dentes superiores sem que houvesse diferenças qualitativas na microbiota de fumantes e não-fumantes.

Respostas menos favoráveis da profundidade de sondagem 
em fumantes também são observadas após as terapias periodontais ${ }^{1,92,99}$ Uma menor redução da profundidade de sondagem, após terapia periodontal não cirúrgica, para todas as regiões e uma maior diferença para a região antero-superior foi observada por PREBER; BERGSTRÖM ${ }^{92}$.

Quando relacionada a terapia de manutenção, JANSSON; HAGSTRÖM ${ }^{60}$, encontraram maiores profundidades de sondagem em indivíduos que interromperam o tratamento, independente do hábito de fumar. Quando a variável do fumo foi considerada, os autores demonstraram que indivíduos fumantes, sem manutenção periodontal, aumentaram o risco de progressão da periodontite.

Considerando o aspecto relativo a recessões gengivais entre fumantes e não-fumantes (Tabela 2, figura 2), não se pôde verificar diferenças significantes para nenhuma das análises realizadas. Também não foi possível verificar uma tendência constante para nenhum dos grupos. Evidentemente, não se pode pelos resultados obtidos neste estudo, afirmar que o tabagismo não possa interferir no aspecto recessões, mas há que se considerar os múltiplos fatores envolvidos na etiologia das recessões que não foram abordados. Outro aspecto a ser considerado é que o número de indivíduos abordados no estudo não seja o ideal para uma análise mais precisa desse aspecto.

No estudo de ALBANDAR $^{2}$ foram comparados fumantes de cigarro, cachimbo e charuto, relatando, que apresentaram maior prevalência de recessões gengivais $\geq 3 \mathrm{~mm}$ em relação aos não-fumantes.

Neste mister, DAMÉ ${ }^{31}$, relacionou a recessão gengival entre 
fumantes e não-fumantes, com efeitos mais prejudiciais em fumantes, encontrando maior número de sítios com perda de inserção, indicação de assimetria nesses sítios com recessão, maior tendência à recessão em mulheres e uma tendência de aumento da recessão com a idade.

Outros trabalhos comentam a relação do tabaco como indicador de risco para recessões ${ }^{48}$ e de perda de inserção horizontal em furcas ${ }^{63}$.

O parâmetro clínico nível de inserção clínica (Tabela 3 figura 3), de extrema importância na análise periodontal e também empregado neste estudo, em linhas gerais, seguiu o mesmo padrão verificado, quando da análise da profundidade de sondagem; embora tenha se verificado significância estatística apenas nos sítios palatinos dos dentes superiores posteriores, houve tendência geral de maiores valores para o grupo de fumantes.

Trabalhos atuais também relacionam fumantes com maior perda de inserção periodontal $\left.\right|^{2,7,42,45,52,69}$.

O estudo de HAFFAJEE; SOCRASKY ${ }^{52}$ teve resultados semelhantes aos deste estudo. Os autores examinaram as características clínicas de doença periodontal e padrões de perda de inserção entre indivíduos fumantes usuais, fumantes ocasionais e nunca fumantes, em 6 locais por dente, em todos os dentes, excluindo os terceiros molares. 0 estudo mostrou que este parâmetro foi mais significante em fumantes usuais do que nos outros 2 grupos, particularmente nos sítios palatinos superiores e nos dentes antero-inferiores. Segundo os autores, essas maiores perdas 
observadas nesses sítios sugeriram possibilidade de um efeito local do cigarro.

MARTINEZ-CANUT et al. ${ }^{73}$ também relacionaram a dosereação de cigarros em relação à perda de inserção clínica, mostrando uma relação direta de maior perda de inserção com o aumento do número de cigarros consumidos.

Outro parâmetro menos favorável em fumantes é em relação ao ganho de inserção após terapia periodontal. $\mathrm{AH}$ et al. ${ }^{1}$ avaliaram o efeito do fumo na resposta clínica à terapia periodontal cirúrgica e não cirúrgica entre fumantes e não-fumantes. A análise demonstrou que fumantes exibiram significantemente menor ganho do nível de inserção, imediatamente após terapia ativa e após terapia de manutenção.

Sob este mesmo aspecto, TONETTI; PINI-PRATO; CORTELLINI $^{111}$ ao relacionarem o efeito do cigarro na RTG encontraram menor ganho de inserção em fumantes em comparação ao grupo controle.

Em relação ao índice gengival (Tabela 4 e Figura 4), a análise comparativa entre os grupos mostrou que das 16 situações analisadas, houve significância estatística em 12, sempre com valores maiores para os não-fumantes, o que reflete clinicamente maior exuberância clínica inflamatória nesse grupo.

Divergências em relação às condições gengivais são enunciadas em vários artigos. Alguns trabalhos mais antigos correlacionavam o índice gengival, não considerando os padrões de higiene oral, mostrando maior evidência de inflamação em fumantes, $5,80,89,104$. Nesse 
contexto, BAAB, ÔBERG ${ }^{8}$ apresentaram os efeitos do cigarro no fluxo sangüíneo, causando antes aumento significante e não diminuição na circulação sanguínea gengival, concluindo que a teoria de que fumar prejudicaria o fluido sangüíneo gengival poderia não ser verdadeira em fumantes. Só que este resultado poderia estar relacionado com a pouca idade dos indivíduos que participaram do experimento, sendo de 19 a 25 anos e ao pouco tempo do hábito de fumar (05 a 15 cigarros por dia).

Vários trabalhos revelaram que os sinais clínicos de inflamação são menos evidentes em fumantes ${ }^{4,14,21,26,52,68,80}$ pela ação do fumo na reação vascular, diminuindo o fluxo sangüíneo. Outras pesquisas, inclusive, relataram a reação dose-dependente que diminuiria os sinais clínicos proporcionalmente ao consumo de tabaco $^{19}$. Em contraposição, alguns trabalhos não demonstraram relação nas condições gengivais em indivíduos com saúde gengival ${ }^{12,86}$ ou com doença periodontal ${ }^{13}$.

Quanto ao índice de sangramento gengival (ISG) (Tabela 5 e Figura 5) embora não tenha havido diferenças estatisticamente significantes, houve uma tendência geral a sítios mais sangrantes no grupo de nãofumantes e da mesma forma que o índice gengival, os aspectos clínicos parecem ser mascarados pelo tabagismo.

O sangramento gengival é considerado um sinal objetivo associado a gengivites e periodontites. Há algumas evidências de que o tabaco pode estar associado com sinais e sintomas menos expressivos na inflamação periodontal, tais como sangramento gengival, eritema e edema, indicando uma influência supressora na resposta inflamatória 
GOULTSCHIN et al. ${ }^{43}$ compararam indivíduos com média de idade similar ao deste trabalho e também mostraram que fumantes tiveram menor índice de sangramento gengival que não-fumantes, atribuindo este achado a uma redução no fluxo gengival provocado pela nicotina. Outros estudos, contudo, falharam em confirmar esses achados ${ }^{1,49}$.

Também, no estudo de BERGSTROM, BOSTROM ${ }^{15} \mathrm{e}$ BERGSTROM, FLODERUS-MYRHED ${ }^{19}$ houve evidências de que a dosereação, torna a reação hemorrágica menos evidente em fumantes.

Outro aspecto essencial nesta análise clínica é o acúmulo de placa bacteriana. (Tabela 6 e Figura 6). Embora se verifique significância estatística apenas para os sítios linguais anteriores e posteriores, para todas as demais situações analisadas houve tendência geral de maior acúmulo de placa em fumantes.

Existem controvérsias em relação ao acúmulo de placa em fumantes. A análise deste estudo está em concordância com alguns trabalhos ${ }^{1,12,68,94,96,111}$,enquanto outros acharam menor acúmulo de placa em fumantes ${ }^{38}$ ou escores de placa similares s, $^{4,14,20,21,26,68,94,109}$ entre os grupos de fumantes e não-fumantes. Alguns trabalhos, ao equacionarem os grupos pela higiene oral, não mostraram diferença significante no acúmulo de placa. $17,18,69,80,95,104$.

Os estudos de BERGSTRÖM;ELIASSON; PREBER ${ }^{18}$, LINDEN; MULLALY ${ }^{69}$ mostraram que em indivíduos fumantes e nãofumantes com o mesmo nível de higiene oral, não houve diferença 
significante na média do índice de placa. Foi concluído existirem fortes evidências de que o fumo afeta a parte mineral do tecido ósseo, sugerindo influência direta na saúde periodontal, independentemente da infecção da placa, sendo um fator determinante de destruição periodontal ${ }^{18}$.

Embora não tenha sido o objetivo deste trabalho, a diferença em relação a qualidade da placa bacteriana vem sendo pesquisada. Alguns autores não mostram esta associação ${ }^{64,68}$,enquanto outros confirmam a diferença na qualidade microbiológica ${ }^{11,12,45,51,64,67,84,115}$. A diferença na prevalência das espécies anaeróbicas ajudaria a explicar a maior severidade de destruição periodontal em fumantes, desde que mais sítios estão em risco por estarem colonizados por patogênos potenciais, em pacientes fumantes do que em não-fumantes ${ }^{52,115}$.

Em relação ao estudo histológico, os 10 pacientes selecionados para a intervenção cirúrgica, assim como os demais, que só participaram da parte clínica, não reportaram histórias de terapia periodontal nos últimos 6 meses ou de doenças que poderiam afetar a microcirculação. Dessa maneira, pretendeu-se analisar os dados histomorfológicos do tecido conjuntivo da gengiva livre, no grupo de fumantes e de não-fumantes, estimando uma possível relação com os dados clínicos na área.

A análise histológica da gengiva marginal em 3 dos 5 pacientes não-fumantes mostrou quadro inflamatório acentuado (Figura 15, Figura 20). Tanto o epitélio gengival, quanto o sulcular e juncional tiveram modificações caracterizando intenso processo inflamatório (Figura 15, Figura 16).O tecido conjuntivo da lâmina própria mostrou fibras colágenas 
espessas, grande número de vasos hiperêmicos e células inflamatórias linfoplasmocitárias, de arranjo difuso ou em formações granulomatosas (Figura 16, Figura 17, Figura 18) e degradação das fibras colágenas (Figura 21, Figura 22), caracterizando a reação inflamatória crônica na região. Em dois outros casos, a reação foi mais branda.

A análise histológica de fumantes mostrou dois quadros bem distintos. O primeiro quadro inflamatório foi menos acentuado em toda extensão da lâmina própria (Figura 7, Figura 8). O segundo quadro mostrou processo inflamatório mais intenso próximo à bolsa, exibindo hiperplasia do epitélio sulcular com formação de projeções papilares em forma de espículas, fragmentação do epitélio juncional (Figura11, Figura 12), intenso infiltrado linfoplasmocitário e degradação das fibras colágenas (Figura 13, Figura 14).

É interessante traçar um parâmetro das análises histológicas com as condições clínicas. Os grupos não diferiram em relação à média de PS que foi de $6,2 \mathrm{~mm}$, anteriormente à intervenção cirúrgica, mesmo porque o critério de seleção previa PS $>5 \mathrm{~mm}$. O índice de placa teve tendência de maior média para fumantes apesar de não estatisticamente significante e o ISG (Índice de sangramento gengival) foi positivo para os dois grupos, com tendência de maiores médias para fumantes. A maior diferença foi na média do IG(Índice gengival), sendo de 0,8 para fumantes e 2,6 para não-fumantes. Pacientes fumantes apresentaram aspecto histológico com menor reação inflamatória e menor vascularização em relação aos não-fumantes. Essas observações, talvez estejam relacionadas ao efeito vasoconstritor da 
nicotina, provocando resposta no hospedeiro menos favorável à defesa local em fumantes e conseqüentemente com condição clínica menos evidente. Nesse sentido, estudos ${ }^{15,53}$,também evidenciam o prejuízo funcional na microcirculação gengival.

Apesar de não avaliada, especificamente, a reação vascular mostrou aspecto mais congesto de células inflamatórias em vasos de nãofumantes. A literatura apresenta evidências neste sentido. No estudo de SÖLDERHOLM et al ${ }^{106,}$ os autores avaliaram os vasos sangüíneos situados na margem gengival, durante a gengivite em cães Beagle, encontrando maior diâmetro vascular.

HOCK; NUKI ${ }^{55}$ também estudaram o fluxo sangüíneo e reação vascular da gengiva livre em animais. O estado de saúde gengival foi avaliado clinicamente, histologicamente e com microscópio vital. Os resultados indicaram que a gengiva livre que nunca tivesse sido envolvida em inflamação exibiu morfologia vascular descrita como rede. Com a manifestação de mudanças inflamatórias histopatológicas, a rede obtinha aparência de argola ou seja um maior diâmetro vascular.

O estudo de HUNTER ${ }^{57}$ em humanos revelou mudanças vasculares quantitativas, com o avanço da doença periodontal em nãofumantes. O número e diâmetro dos vasos estavam aumentados com o avanço da doença periodontal.

A reação vascular em relação ao fumo parece ser diferente 20,61. No trabalho de JOHNSON; FUNG; SQUIER ${ }^{61}$ foi examinada a característica capilar em ratos submetidos à administração sistêmica de 
nicotina em dose similar a 1 carteira de cigarro por dia, sendo encontradas alterações morfológicas na microvasculatura da mucosa oral, com comprimento capilar menor em fumantes, sugerindo que isto poderia implicar na etiologia da doença da mucosa oral, incluindo doença periodontal, devido ao prejuízo na resposta do hospedeiro.

Em contrapartida, a densidade vascular em gengiva marginal não parece ser influenciada pelo fumo moderado desde que prevaleçam condições de saúde gengival $^{86}$.

Como já citado anteriormente, dos pacientes participantes da amostra, 10 indivíduos (5 fumantes e 5 não-fumantes) foram submetidos a procedimento cirúrgico em sítios com bolsas nas faces palatinas de dentes posteriores. Nesses sítios específicos, apuraram-se as médias dos índices clínicos e dos tecidos obtidos para análise histomorfométrica, analisou-se a densidade de volume(\%) de tecido normal e inflamado, análise celular de células inflamatórias e fibroblastos.

$\mathrm{Na}$ análise conjunta dos 10 indivíduos, verificou-se que houve significância estatística para o índice gengival com maior média para os pacientes não-fumantes (Tabela 7, Figura 23); quanto à análise das variáveis histomorfométricas, houve significância para o tecido normal com maior média para os fumantes, enquanto na análise de tecido inflamado e células inflamatórias, houve significância com maiores médias para o grupo de não-fumantes (Tabela 7 e Figura 24).

Deve-se observar que o percentual de tecido inflamado e o número de células inflamatórias em não-fumantes foi praticamente o dobro 
em relação aos fumantes. Nota-se, também, uma condição gengival comparativamente significante entre os grupos porém, sendo 3 vezes maior para os não-fumantes (Tabela 7, Figura 23).

A literatura mostra que as respostas celulares para as substâncias do tabaco variam muito e podem estar relacionadas a componentes específicos do tabaco e ao tipo celular. Por exemplo, a habilidade de sobrevivência de leucócitos PMN está diminuída e sua atividade de fagocitose e quimiotaxia também são afetadas $^{66}$. Em adição, ocorre estímulo de degradação celular, supressão da proliferação de linfócitos e diminuição de sua viabilidade e redução da produção de anticorpos ${ }^{56}$.

EICHEL et al. ${ }^{36}$ já estudavam a perda da função leucocitária em humanos por causa do fumo. No estudo de KENNEY et al. ${ }^{66}$, o efeito de fumar resultou em diminuição da viabilidade e atividade de fagocitose de leucócitos polimorfonucleares orais, prejudicando a quimiotaxia e migração associadas à inflamação gengival. Este prejuízo na atividade funcional de fagócitos poderia diminuir a produção de anticorpos $\lg G 2$, afetando a composição da placa subgengival. Desta maneira, resultando em diferenças nos aspectos clínicos, imunológicos e locais entre fumantes e não-fumantes, com expectativa de uma microbiota mais anaeróbica em fumantes ${ }^{64}$.

PABST et al. $^{84}$ relataram que a nicotina pode inibir a função antimicrobiana aeróbica de neutrófilos e macrófagos, alterando a ecologia microbiológica na cavidade oral. Isto pode ser um mecanismo pelo qual a nicotina compromete a saúde oral de fumantes. Nestes usuários, a inibição 
de funções de fagócitos pela nicotina pode comprometer sua habilidade bactericida para os patógenos periodontais, ou a sinalização da presença de infecção para outras células do sistema.

O fumo também tem sido relacionado como supressor dos inibidores de proteases, em condições de periodontite, podendo ser um mecanismo pelo qual a resposta inflamatória é afetada ${ }^{88}$,entretanto, a atividade sobre neutrófilos em relação ao volume de fluido sulcular gengival é limitada, sob condições de gengiva levemente inflamada ou sadia ${ }^{84}$.

Uma reação inflamatória menos pronunciada, com menor sangramento e eritema gengival em indivíduos fumantes e não-fumantes com formação de placa similar também foi relatada no estudo de GOULTSCHIN et al. ${ }^{43}$.

Durante recentes décadas, muitos estudos têm mostrado que as células do ligamento periodontal (PDL) estão envolvidas na regeneração periodontal $^{35,77}$. Alguns trabalhos evidenciam o poder inibitório do fumo na proliferação, inserção e quimiotaxia de fibroblastos ${ }^{41,59,98}, 0$ que poderia explicar, pelo menos em parte, o aumento da incidência e severidade de doenças periodontais.

RAULIN et al $^{98}$ observaram que a exposição de fibroblastos humanos à nicotina resultou em alterações estruturais, diminuindo a capacidade de inserção dessas células às superfícies radiculares ou plásticas, relatando que esses achados poderiam ser o fator de menor redução de profundidade de sondagem após terapias cirúrgicas.

Alguns estudos, como o de PEACOCK et al. ${ }^{85}$, analisaram a 
interferência da nicotina sobre a capacidade de adesão de fibroblastos gengivais humanos, demonstrando um efeito positivo. Os resultados revelaram que a nicotina aumenta a capacidade de adesão dos fibroblastos, porém, em baixa concentração estimularia a proliferação e em concentrações maiores, não pareceu ter efeito significativo.

Sob este aspecto e considerando que os indivíduos fumantes consumiam em média 1 carteira por dia, a análise comparativa (Tabela 7 , Figura 25) não mostrou diferença estatisticamente significante entre os grupos em relação ao número de fibroblastos gengivais, porém houve tendência similar entre os grupos com média um pouco maior no número de fibroblastos para fumantes.

Os parâmetros clínicos e histomorfométricos discutidos nesse trabalho parecem estar condizentes com os aspectos histomorfológicos relatados anteriormente.

Ao se analisar essas mesmas condições, tentando correlacionar as variáveis clínicas e histomorfométricas dos 10 pacientes conjuntamente (Tabela 8), não se estabeleceu correlação significante. Entretanto, ao se correlacionar os mesmos índices intra-grupos, houve significância negativa na correlação índice gengival-células inflamatórias apenas para os 5 pacientes fumantes (Tabela 9). Este dado parece ser explicado, pelo já exposto em relação ao efeito vasoconstritor da nicotina na quimiotaxia celular, mascarando as condições clínicas.

A resposta do hospedeiro fumante é, portanto, prejudicada de duas formas. Localmente, pela redução no fluxo sangüíneo com diminuição 
no número de células inflamatórias, menor oxigenação gengival e enfraquecimento da resposta defensiva ${ }^{20,21}$. Sistemicamente, afetando as respostas imunes e inflamatórias pela redução da produção de anticorpos ${ }^{39}$ e pela inibição das funções de neutrófilos ${ }^{71}$ em particular, quimiotaxia e fagocitose, dessa maneira, enfraquecendo a resposta defensiva do hospedeiro ${ }^{27}$.

Outro propósito deste trabalho foi comparar o número de dentes ausentes por área (anterior e posterior) e arcada(superior e inferior) dos grupos fumantes e não-fumantes (Tabela 11). Neste aspecto, não se pôde estabelecer condição significante para nenhuma das situações, porém houve tendência de maior perda de dentes superiores nos fumantes e maior perda de dentes inferiores nos não-fumantes.

O estudo epidemiológico de AXELSSON; PAULANDER; LINDHE7 examinou a condição periodontal e os hábitos de fumar de 1093 indivíduos em faixas etárias de 35 a 75 anos, concluindo que o fumo é um fator de risco significante para perda dentária. Esta mesma afirmação foi relatada em relação aos tipos de fumo no estudo de ALBANDAR et al. ${ }^{2}$,sugerindo que fumantes de cigarro, charuto ou cachimbo possuem maior prevalência de problemas periodontais e maiores perdas dentárias do que não-fumantes.

Ainda nesta análise, no grupo de fumantes, procurou-se correlacionar as perdas dentárias com o número de cigarros fumados por dia e o tempo do vício por ano(Tabela 11).

As médias usadas para esta análise foram baseadas em todos os fumantes, incluindo todos os dentes, consumo de 29 cigarros por dia por 
um tempo médio de 23 anos. Houve correlação significante de perda dentária somente dos dentes inferiores posteriores com o tempo de ação do tabaco (Tabela 12).

A relação da reação dose-dependente é evidenciada em muitos trabalhos como potencializadora das injurias ao periodonto ${ }^{07,17,25}$. No recente estudo de BERGSTRÖM; ELIASSON; DOCK ${ }^{17}$ foram avaliados todos os dentes de 50 indivíduos fumantes usuais, 61 ocasionais e 133 nãofumantes, indicando que a relação dose-dependente é um fator que aumenta os efeitos desagradáveis provocados pela nicotina, mesmo em indivíduos com bons hábitos de higiene oral. Os autores relataram que a condição de fumantes ocasionais foi intermediária entre fumantes usuais e não-fumantes, sugerindo que os fumantes ocasionais que pararam de fumar, tiveram uma condição de saúde periodontal melhor do que os fumantes usuais, embora pior que os não-fumantes. Esses achados sugeriram que parar de fumar pode permitir uma normalização em direção às condições de não-fumantes. Essa correlação também foi evidenciada no estudo de HAFFAJEE; SOCRANSKY ${ }^{51}$, mostrando que fumantes usuais tiveram significantemente mais dentes ausentes em relação a fumantes ocasionais e nunca fumantes.

\section{O estudo retrospectivo de JANSON, HAGSTROM ${ }^{60}$,em relação} a terapia de suporte periodontal relata que fumantes têm alto risco de recorrência de periodontite durante a fase de manutenção, reforçando a necessidade de reduzir a freqüência de abandono de tratamento, a fim de melhorar o prognóstico periodontal 
Todos os parâmetros aqui comentados são de fundamental importância na prevalência do tabaco como fator de risco periodontal. De maneira geral, procurou-se discutir os mais relacionados com a proposição deste trabalho. Vários aspectos devem ser considerados e mais pesquisas devem ser realizadas a fim de elucidar as divergências em relação à interrelação tabaco-doença periodontal. 


\section{Conclusões}




\section{Conclusões}

Baseado na metodologia empregada e considerando suas limitações, pode-se concluir:

1A- Que o tabagismo agrava certamente a profundidade de sondagem, o nível de inserção clínica e o índice de placa.

1B- Que as recessões não são condições claramente só ligadas ao tabagismo.

1C- Que os índices gengival e de sangramento gengival sofrem certamente interferência do tabagismo, mascarando-os.

2- Que o quadro histopatológico é menos exuberante nos fumantes do que nos não- fumantes, em função do tabagismo mascarar as alterações teciduais, com menor infiltrado inflamatório e menor densidade de tecido inflamado.

4- Que há correlação negativa entre índice gengival e infiltrado inflamatório nos pacientes fumantes.

5- Que em fumantes houve tendência a maiores médias de perdas dentárias no arco superior, porém o número de dentes perdidos no arco postero-inferior foi estatisticamente significante e o tempo do vício influenciou nessas perdas mais que o número de cigarros consumidos por dia. 
Referências Bibliográficas 


\section{Referências Bibliográficas*}

$1 \mathrm{AH}, \mathrm{M} . \mathrm{K}$. B. et al. The effect of smoking on the response to periodontal therapy. J. Clin. Periodont., v.21, p.91-7, 1994.

2 ALBANDAR, J. M. et al. Cigar, pipe, and cigarette smoking as risk factors for periodontal disease and tooth loss. J. Periodont., v.71, n.12, dez. 2000.

3 AINAMO, J.; BAY, I. The visible plaque (VPI) and gingival bleeding index (ISG) system. J. Clin. Periodont., 1975.

4 ALEXANDER, A. G. The relationship between tobacco smoking, calculus, plaque accumulation and gingivitis. Dent Health., v.9, n.6, 1970 apud RIVERA-HIDALGO, F. Smoking and periodontal disease. A review of the literature. J. Periodont., v.57, p.617-24, 1986.

5 ARNO, A. et al. O Incidence of gingivitis as related to sex, occupation, tobacco consumption, toothbrushing, and age. Oral Surg., v.11, p.587, 1958.

6 ARNO, A. et al. Alveolar bone loss as a function of tobacco consumption. Acta Odontol. Scand., v.17, n.3, 1959.

7 AXELSSON, P.; PAULANDER, J.; LINDHE, J. Relationship between smoking and dental status in 35, 50, 65 and 75 years old individuals. J. Clin. Periodont., v.25, p.297-305, Munksgaard, 1998.

\footnotetext{
* Normas recomendadas para o uso no âmbito da Universidade de São Paulo, com base no documento "Referências Bibliográficas: exemplo", emandos do Conselho Supervisor do Sistema Integrado de Bibliotecas da USP, em reunião de 20 de setembro de 1990.
} 
8 BAAB, D. A.; ÔBERG, P. A. The effect of cigarette smoking on gingival blood flow in humans. J. Clin. Periodont., v.14, p.418-24, 1987.

9 BAIN, C. A.; MOY, P. K. The influence of smoking on bone quality and implant failure. Int. J. Oral Maxillofac. Implants., v.8, n.1, p.123, jan.feb. 1992.

10 BAIN, C. A.; MOY, P. K. The association between the failure of dental implants and cigarette smoking. Int. J. Oral Maxillofac. Implants., v.8, p.609-15, 1993.

11 BARDELL, D. Viability of six species of normal oropharyngeal bacteria after exposure to cigarette smoke in vitro. Microbios., v.32, n.7, 1981 apud RIVERA-HIDALGO, F. Smoking and periodontal disease. A review of the literature. J. Periodont., v.57, p.617-24, 1986.

12 BASTIANN, R. J.; WAITE, I. M. Effects of Tobacco Smoking on Plaque Development and Gingivitis. J. Periodont., v.49, p.480-2, Sep., 1978.

13 BERGSTRÖM, J. Cigarette smoking as risk factor in chronic periodontal disease. Community Dent. Oral. Epidemiol., v.17, p.245-7, 1989.

14 BERGSTRÖM, J. Oral hygiene compliance and gingivitis expression in cigarette smokers. Scand. J. Dent. Res., v.98, p.497-503, 1990.

15 BERGSTRÖM, J.; BOSTRÖM, L. Tobacco smoking and periodontal hemorrhagic responsiveness. J. Clin. Periodont., v.28, p.680-5, Munksgaard, 2001. 
16 BERGSTRÖM, J.; ELIASSON, S. Cigarette smoking and alveolar bone heigh in subjects with a high standard of oral hygiene. J. Clin. Periodont., v.14, n.8, p.466-9, Sept., 1987.

17 BERGSTRÖM, J.; ELIASSON, S.; DOCK, J. Exposure to tobacco smoking and periodontal health. J. Clin. Periodont., v.27, p.61-8, Munksgaard, 2000.

18 BERGSTRÖM , J.; ELIASSON, S.; PREBER , H. Cigarette smoking and periodontal bone loss. J. Periodont., v.62, p.242-6, 1991.

19 BERGSTRÖM, J.; FLODERUS-MYRHED, B. Co-twin control study of the relationship between smoking and some periodontal disease factors. Community Dent. Oral Epidem., v,11, n.2, p.113-6, Apr., 1983.

20 BERGSTRÖM, J.; PERSSON, L.; PREBER, H. Influence of cigarette smoking on vascular reaction during experimental gingivitis. Scand. J. Dent. Res., v.96, n.1, p.34-9, Feb, 1988.

21 BERGSTRÖM, J.; PREBER, $\mathrm{H}$. The influence of cigarette smoking on the development of experimental gingivitis. J. Periodont. Res., v.21, p.668-76, 1986.

22 BERGSTRÖM, J.; PREBER, H. Tobacco use as a risk factor. $\mathbf{J}$. Periodont., v.65, n.5, p.545-50, May, 1994.

23 BERNZWEIG, E. et al. Nicotine and smokeless tobacco effects on gingival and peripheral blood mononuclear cells. J. Clin. Periodot., v.25, p.246-52, 1998. 
24 BOLIN, A. et al. S. Proximal alveolar bone loss in a longitudinal radiographic investigation. IV. Smoking and factors influencing the progress in a material of individuals with at least 20 remaining teeth. Acta Odont. Scand., v.44, n.5, p.263-9, Sept., 1986.

25 BOLIN, A. et al. The effect of changed smoking habits on marginal alveolar bone loss: a longitudinal study. Swed. Dent. J., v.17, p.2116, 1993.

26 BOSTRÖM, J.; LINDER, L. E.; BERGSTRÖM, J. Influence of smoking on the outcome of periodontal surgery. A 5 year follow-up. J. Clin. Periodont., v.25, p.194-201, Munksgaard, 1998.

27 BRIDGES, R. B. et al. Effect of cigarette smoke components in vitro chemotasies of human polymorphonuclear leukocytes. Infection and Immunity, v.16, p.240-8, 1977.

$28 \mathrm{CHECCHI}$, L. et al. The effects of nicotine and age on replication and viability of human gingival fibroblasts in vitro. J. Clin. Periodontol v.26: p 636 n 642, 1999.

29 CLARKE, N. G.; CAREY, S. E. Etiology of chronic periodontal disease: an alternative perspective. J. Am. Dent. Assoc., v.110, p.689-91, 1985.

30 CUFF, M. J. A. et al. The presence of nicotine on root surfaces of periodontally diseased teeth in smokers. J. Periodont., v.60, p.564-9, 1989. 
31 DAMÉ, J. A. M. Monitoração da progressão da doença periodontal em pacientes fumantes e não-fumantes sem tratamento da doença periodontal. Bauru, 1996, 150p. Dissertação (Mestrado) Faculdade de Odontologia de Bauru, Universidade de São Paulo.

32 DANIELSEN, B. et al. Effect of cigarette smoking on the transition dynamics in experimental gingivitis. J. Clin. Periodont., v. 17, p. 159$164,1990$.

33 DE BRUYN, H.; COLLAERT, B. The effect of smoking on early implant failure. Clin. Oral Impl. Res., v.5, n.4, p.260-4, Apr., 1994.

34 EGELBERG, J. The blood vessels of the dento-gingival junction. $\mathbf{J}$. Periodont. Res., v. 1, p. 163-179, 1966.

35 EGELBERG, J. Regeneration and repair of periodontal tissues. $\mathbf{J}$. Periodont. Res., v.22, p.233-42, 1987.

36 EICHEL, B.; SHAHRIK, H. A. Tobacco smoke toxicity: loss of human oral leukocyte function and fluid cell metabolism. Science. v.166, p.1424, 1969 apud RIVERA-HIDALGO, F. Smoking and periodontal disease. A review of the literature. J. Periodont., v.57, p.617-24, 1986.

37 FELdMAN, R. S.; ALMAN, J. E.; CHAUnCEY, H. H. Periodontal disease indexes and tobacco smoking in healthy aging men. Gerodontics., v.3, n.1, p.43-6, feb. 1987.

38 FELDMAN, R. S.; BRAVACOS, J. S.; ROSE, C. L. Association between smoking different tobacco products and periodontal disease indexes. J. Periodont., v.54, p.481, 1983. 
39 FINKL-FEA, J. F. et al. Cigarette smoking and hemaglutination inhibition response to influenza after natural disease and immunization. American Review of Respiratory Disease, v.104, p.368-76, 1971.

40 GELSKEY, S. C. Cigarette smoking and periodontitis: methodology to assess the strength of evidence in support of a causal association. Comm. Dent. Oral Epidemiol., v.27, p.16-24, 1999.

41 GIANNOPOULOU, C.; GEINOZ, A.; CIMASONI, G. Effects of nicotine on periodontal ligament fibroblasts in vitro. J. Clin. Periodont., v.26, p.49-55, Munksgaard, 1999.

42 GONZÁLES, Y. M. Et al. Serum cotinine levels, smoking, and periodontal attachment loss. J. Dent. Res., v.75, n.2, p.796-802, 1996.

43 GOULTSCHIN, J. et al. Association of smoking with periodontal treatment needs. J. Periodont., v.61, p.364-7, 1990.

44 GRITZ, E. R. et al. Plasma nicotine and cotinine concentrations in habitual smokeless tobacco users. Clin. Pharmacol. Ther., v.30, p.201-9, 1981.

45 GROSSI, S. G. et al. Assessment of risk for periodontal disease (II). Risk indicators for alveolar bone loss. J. Periodont., v.66, p.23-9, 1995.

46 GROSSI, S. G. et al. Response to periodontal therapy in diabetics and smokers. J. Periodont., v.67, p.1094-102, 1996.

47 HAAS, R, et al. The relationship of smoking on peri-implant tissue: a retrospective study. J. Prosthet. Dent., v.76, n.6, p.592-6, jun. 1996. 
48 HABER, J. Cigarette smoking: a major risk factor for peridontitis. Comp. Continuig Educ. Dent., v.15, n.8, p.1002-14, aug. 1994.

49 HABER J. et al. Evidence for cigarette smoking as a major risk factor for periodontitis. J. Periodont., v.64, n.1, p.16-23, jan. 1993.

50 HABER, J.; KENT, R. L. Cigarette smoking in a periodontal practice. J. Periodont., v.63, n.2, p.100-6, feb., 1992.

51 HAFFAJEE, A. D.; SOCRANSKY, S. S. Relationship of cigarette smoking to the subgingival microbiota. J. Clin. Periodontol., v.28, n.388, p.377, 2001.

52 HAFFAJEE, A. D.; SOCRANSKY, S. S. Relationship of cigarette smoking to attachment level profiles. J. Clin. Periodont., v.28, p.283-95, Munksgaard, 2001.

53 HANIOKA, T. et al. Oxygen sufficiency in the gingiva of smokers and non-smokers with periodontal disease. J. Periodont., v.71, p.12, n.1846-51, 2000.

54 HANSSON, B.; LINDHE, J.; BRANEMARK, P. Microvascular topography and function in clinically healthy and chronically inflamed dentogingival tissues - a vital microscopy study in dogs. Periodontics., v.6, p.264-73, 1968.

55 HOCK, J.; NUKI, K. A vital microscopy study of the morphology of normal and inflamed gingiva. J. Periodont. Res., v.6, p.81-8, 1971. 
56 HOST, P. G.; KEAST, D. Environmentally induced in immunological function: Acute an chronic effects of inhalation of tobacco smoke and other atmospherie contaminants in man and experimental animals. Bacterial Rev., v.41, p.205-16, 1977.

57 HUNTER, N. Vascular expansion in chronic periodontitis. J. Oral. Pathol. Med., v.20, p.433-7, 1991.

58 ISMAIL, A. I.; BURT, B. A.; EDLUNK, S. A. Epidemiologic patterns of smoking and periodontal disease in the United States. J. Am. Dent. Assoc., v.106, p.617-21, 1983.

59 JAMES, J. A. et al. Effects of Tobacco Products on the Attachment and Growth of Periodontal Ligament Fibroblasts. J. Periodont.,. v.II, n.70. p.518-25, 1999.

60 JANSSON, L. E.; HAGSTRÖM, K. E. Relationship between compliance and periodontal treatment outcome in smokers. J. Periodont., v.73, n.6, p.602-7, jun. 2002.

61 JOHNSON, G. K.; FUNG, Y. K.; SQUIER, C. A. Effects of systemic administration of nicotine on capillaries in rat oral mucosa. J. Oral Pathol. Med., v.18, p.230-32, 1989.

62 JONES, J. K.; TRIPLETT, R. G. The relationship of cigarette smoking to impaired intraoral wound healing: a review of evidence and implications for patient care. Int. J. Oral. Maxillofac. Implants., v.50, n.3, p.237-9, mar. 1992. 
63 KALDAHL, W. et al. Long-term evaluation of periodontal therapy: I. Response to 4 therapeutic modalities. J. Periodontol., v.67, p.63$102,1996$.

64 KAMMA, J. J.; NAKOU, M.; BAEHNI, P.C. Clinical and microbiological characteristics of smokers with early onset periodontitis. $\mathbf{J}$. Periodont. Res., v.34, p.25-33, 1999.

65 KARDACHI, B. J. R.; CLARKE, N. G. An etiology of acute necrotising ulcerative gingivitis: a hipothetical explanation. J. Periodont., v.45, p.830-2, 1974.

66 KENNEY, E. B. et al. The effect of cigarette smoke on human oral polymorphonuclear leukocytes, J. Periodont. Res., v.12, p.227, 1977.

67 KENNEY, E. B.; SAXE, S. R.; BOWLES, R. D. The effects of cigarette smoking on anaerobios in the oral cavity. J. Periodont., v.46, p.82, 1975.

68 LIE, M. A. et al. Oral microbiota in smokers and non-smokers in natural and experimentally-induced gingivitis. J. Clin. Periodont., v.25, p.677-86, 1998.

69 LINDEN, G. J.; MULLALLY, B. H. Cigarette Smoking and periodontal destruction in young adults. J. Periodont., v .65, p.718-23, 1994.

70 LÖE, H. The gingival index, the plaque index and the retention index systems. J. Periodont., v.36, p.610, 1967. 
71 MACFARLANE, G. D. et al. Refractory periodontitis associated with abnormal polymorphonuclear leukocyte phagocytosis and cigarette smoking. J. Periodont., v.63, p.908-13, 1992.

72 MARTELLI-JUNIOR, H. et al. Comparação clínica da presença de lesões de furca entre pacientes fumantes e não-fumantes. Rev. Brás. Cir. Periodontia., v.1, n.1, p.26-9, jan/mar. 2003.

73 MARTINEZ-CANUT, P.; LORCA, A.; MAGAN, R. Smoking and periodontal disease severity. J. Clin. Periodont., v.22, p.743-9, 1995.

74 MATHENY, J. L.; JOHNSON, D. T.; ROTH, G. I. Aging and microcirculatory dynamics in human gingiva. J. Clin. Periodont., v.30, p.471-5, Munksgaard, 1993.

75 McGUIRE, J. R. et al. Cotinine in saliva and gingival juncional fluid of smokers with periodontal disease. J. Periodont., v.60, p.176-81, 1989.

76 McLAUGHLIN, W. S. et al. The immediate effects of smoking on gingival blood flow. J. Clin. Periodont., v.20, p.448-51, 1993.

77 MEYER, J. R. The regenerative pretentral of the periodontal ligament. J. Prosthet. Dent., v.55, p.260-5, 1986.

78 MILLER, P. D. Root coverage with the free gingival graft : Factors associated with incomplete coverage, J. Periodont., v.58, p.674-81, 1987. 
79 MITCHELL, B. E.; SOBEL, H. L.; ALEXANDER, M. H. The adverse health effect of tobacco and tobacco-related products. Primary Care., v.26, p.463-98, 1999.

80 MODEER, T.; LAVSTEDT, S.; AHLUND, C. Relation between tobacco consumption and oral Health in Swedish schoolchildren. Acta Odontol Scand., v.38, p.223, 1980 apud RIVERA-HIDALGO, F. Smoking and periodontal disease. A review of the literature. $\mathbf{J}$. Periodont., v.57, p.617-24, 1986.

81 MOSELY, L. H.; FINSETH, F.; GOODY, M. Nicotine and its effects on wound healing. Plast Reconstr. Surg., v.61, p.570-5, 1978.

82 NOCITI-JUNIOR, F. H. et al. Intermittent cigarette smoke inhalation may affect bone volume around Titanium Implants in rats. J. Periodont., v.73, n.9, p.982-7, set. 2002.

83 OMS: A review of current recomendations for the organization and administration of community oral health service in northern and western Europe. Report of Who workshop Copenhagen: Who regional of for Europe, 1982.

84 PABST, M. J. et al. Inhibition of neutrophil and monocyte defensive functions by nicotine. J. Periodont., v.66, n.12, p.1047-55, dec. 1995.

85 PEACOCK, M. E. et al. The effect of nicotine on reproduction and attachment of human gingival fibroblasts in vitro. J. Periodont., v.64, p.658-65, 1993. 
86 PERSSON, L., BERGSTRTÖM, J. Smoking and vascular density of healthy marginal gingiva. Eur. J. Oral Sci., v.106, p.953-7, 1998.

87 PERSSON, L. et al. Tobacco smoking and gingival neutrophil activity in young adults. J. Clin. Periodont., v.26, p.9-13, 1999.

88 PERSSON, L. et al. Tobacco smoking and neutrophil activity in patients with periodontal disease. J. Periodont., v.72, n.1, p.90-95, jan. 2001.

89 PINDBORG, J. J. Tobacco and gingivitis. J. Dent. Res., v.26, p.261, 1947.

90 PINDBORG, J. J. Tobacco and gingivitis. II. Correlation between consumption of tobacco, ulceromembranous gingivitis and calculus. J. Dent. Res., v.28, n.5, p.460-3, oct. 1949.

91 PREBER, H.; BERGSTRÖM, J. Occurrence of gingival bleeding in smoker and non-smoker patients. Acta Odontol. Scand., v.43, p.315-20, 1985.

92 PREBER, H.; BERGSTRÖM, J. The effect of non-surgical treatment on periodontal pockets in smokers and non-smokers. J. Clin. Periodont., v.13, p.319-23, 1985.

93 PREBER, H.; BERGSTRÖM, J. The effect of cigarette smoking on periodontal healing following surgical therapy. J. Clin. Periodont., v.17, p.324-8, 1990. 
94 PREBER, H.; BERGSTROM, J; LINDER, L.E. Occurrence of periopathogens in smoker and non-smoker patients. J. Clin. Periodont., v.19, p.667-71, 1992.

95 PREBER. H.; KANT, T. Effect of tobacco smoking on periodontal tissue of 15- year-old school children. J. Periodont. Res., v.8, p.278, 1973 apud RIVERA-HIDALGO, F. Smoking and periodontal disease. A review of the literature. J. Periodont., v.57, p.617-24, 1986.

96 PREBER, H.; KANT, T.; BERGSTROM, J. Cigarette smoking oral higiene and periodontal health in Swedish army consents. J. Clin. Periodont., v.7, p.106, 1980.

97 PREBER, H.; LINDER, L.; BERGSTRÖM, J. Periodontal healing and periopathogenic microflora in smokers and non-smokers. J. Clin. Periodont., v.22, p.946-52, p.1995.

98 RAULIN, L. A. et al. The Effect of Nicotine on the Attachment of Human Fibroblasts to Glass and Human Root Surfaces in vitro. J. Periodont., v.59, n.5, p.318-25, 1988.

99 RENVERT, S.; DAHLÉN, G.; WIKSTRÔM, M. The clinical and microbiological effects of non-surgical periodontal therapy in smokers and non-smokers. J. Clin. Periodont., v.25, p.153-7, Munksgaard, 1998.

100 RIVERA-HIDALGO, F. Smoking and periodontal disease. A review of the literature. J. Periodont., v.57, p.617-24, 1986. 
101 ROBERTSON, P. B.; WALSH, M. M.; GREENE, J. C. Oral effects of smokeless tobacco use by professional baseball players. Adv. Dent. Res., v.11, p.307-12, 1997.

102 RYDER, M. I.; FUJITAKI, R.; LEBUS, S. Alterations of neutrophil Lselection and CD18 expression by tobacco smoke: implications of periodontal diseases. J. Periodont. Res., v.33, p.359-68, 1998.

103 SARIN, C. L.; AUSTIN, J. C.; NICKEL, W. O. Effects of smoking on digital blood flow velocity. Jama., v.229, p.1327-8, 1974.

104 SHEIHAM, A. Periodontal disease and oral cleanliness in tobacco smokers. J. Periodont., v.42, n.5, p.259-63, may. 1971.

105 SILNESS, J.; LÖE, H. Periodontal disease in pregnancy. Acta odont. scand., v.22, p.121-35, 1964.

106 SÖLDERHOLM, G.; EGELBERG, J. Morphological changes in gingival blood vessels during developing gingivitis in dogs. J. Periodont. Res., v.8, p.16-20, 1973.

107 SOLOMON, H. A.; PRIORE, R. L.; BROSS, I. D. J. Cigarette smoking and periodontal disease. J. Amer. Dent. Ass., v. 77, n.5, p.1081-4, nov.1968.

108 STALLARD, R. Periodontal microcirculation and the gingival juncional fluid. Paradont. Acad. Rev., v.2, p.34-43, 1968. 
109 STOLTENBERG, J. L. et al. Association between cigarette smoking, bacterial pathogens, and periodontal status. J. Periodont., v.64, p.1225-30, 1993.

110 TONETTI, M. S. Cigarette smoking and periodontal diseases: etiology and management of disease. Ann. Periodontol., v.3, p.88-101, 1998.

111 TONETTI. M. S.; PINI-PRATO, G.; CORTELLINI, P. Effect of cigarette smoking on periodontal healing GTR in infrabony defects: a preliminary retrospective study. J. Clin. Periodont., v.22, n.3, p.22934, mar. 1995.

112 WAEBER, B. et al Skin blood flow reduction induced by cigarette smoking. Am. J. Physiol., v.274, p.895-904, 1984.

113 WALD, N. J.; HACKSHAW, A. K. Cigarette smoking: An epidemiological overview. Br. Med. Bull., v.52, p.3-11, 1996.

114 WEIBEL, E.R. Stereological principles of morphometry in electro microscopic citology. Int.Rer. cytol, v.26, p. 235-302, 1969.

115 ZAMBON, J. J. Et al. Cigarette smoking increases the risk for subgengival infection with periodontal Pathogens. J. Periodont., v. 67, p. 1050-4, 1996. 
Abstract

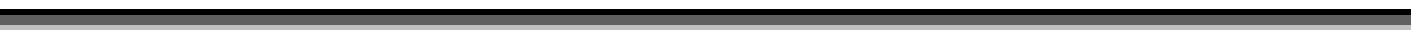




\section{ABSTRACT}

\section{EVALUATION OF CLINICAL AND HISTOLOGICAL PERIODONTAL STATUS IN SMOKERS AND NON-SMOKERS}

Clinical and histological periodontal status were evaluated in smokers and non-smokers. Fifty five subjects took part of the study, 29 smokers and 26 non-smokers, ages ranging from 30 to-50 years, with age average of 40 years. The clinical parameters used were: probing depth(PD), plaque index(PI), gingival index(GI), clinical attachment level (CAL), gingival recession(GR) and gingival bleeding index(GBI). The histological analysis was done by histomorphometry and histomorphology of the gingival connective tissue of the periodontal pocket by 10 subjects, of which 5 were smokers and 5 non-smokers who were randomly selected by the both groups. The time of smoking habit, amounts of cigarette smoked per day and the tooth loss were also considered in smokers. The obtained results showed a tendency of greater averages by probing depth, periodontal attachment level and amount of plaque in smokers, greater average of gingival index for non-smokers, lower average of gingival bleeding for smokers and similar averages of recession in both groups. Histological and clinical effects were less expressive in smokers. This masking of periodontal disease caused by immunological, cellular and vascular reactions, and the time of smoking, can result in less favourable prognosis of the periodontal therapy in smokers.

Key words: smokers, clinical status, histological status 